\title{
CONDICōes Sanitárias de áGuas de PISCINAS de CAMPO GRANDE, .. MATO GROSSO DO SUL
}

\author{
Tese apresentada ao \\ Departamento de Saúde Ambiental \\ da Faculdade de Saúde Pública \\ da Universidade de São Paulo, para \\ obtenção do titulo de \\ Doutor em Saúde Pública.
}

Orientador: Prof. Dr. Aristides Almeida Rocha

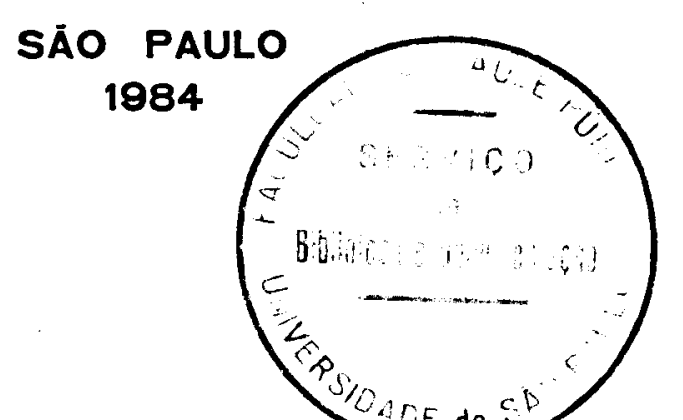


"Crede na ação realizada em equipe e tereis a certeza de não falhar na vida" (LIAUTEY) 
HOMENAGENS 


$$
\begin{gathered}
\text { A minha avö ANTONIA } \\
\text { e aos meus } \\
\text { pais, HEITOR e CLELIA, } \\
\text { pelo estimulo e carinho. }
\end{gathered}
$$


A Dra. ANNETTE SILVA FORONDA, pela dedicação e amizade. 
Ao Prof. JORGE DAVID NASSER, a quem devo, não só o estímulo para a realização deste trabalho, mas $o$ apoio e compreensão como pesquisador, mestre e amigo "in memoriam" 
RECONHECIMENTOS 
Ao or. ARISTIDES ALMEIDA ROCHA, por sua eficien te orientação e confiança.

A Dra. ANNETTE SILUA FORONDA, pela realização das anālises de amebas de vida livre e pela cuidadosa re visão e correção do vernāculo, com profunda dedicação.

As Farmacêuticas Bioquimicas MARCIA DE SOUZA CARVALHO MELHEM e LUSINETE ACTOLE dE qUEIROZ e à Biomédica SHEILA MARIA CARAI, pela valiosa e sincera contribui ção, na execução das anālises de leveduras.

A Farmacêutica Bioquímica LILIAN DOS SANTOS PAES DE BARROS, pelo inestimāvel auxillio nas anālises bacteriológicas.

A Engenheira quỉmica ROSANGELA DOS SANTOS, pela eficiente colaboração na realização das anālises bisicoquimicas.

A Profa. ANA MARIA CERVANTES BARAZA, pela dedi cação e valioso auxilio nas coletas de amostras e na rea lização de anālises de campo. 
AGRADECIMENTOS 
A Universidade Federal do Mato Grosso do Sul, na pessoa do Magnífico Reitor, EDGARD ZARDO, pela con cessão de dispensa para a realização deste trabalho.

As Diretorias dos clubes visitados, pelas $6 \underline{a}$ cilidades concedidas.

A Empresa de Saneamento do Mato Grosso do Sul - SANESUL, na pessoa do Gerente Regional, Eng? JONAS BARBOSA GARCIA, pela presteza em conceder os laboratō rios da Estação de Tratamento de Ägua para a realização das anālises bacteriolōgicas e bisico-químicas.

As Profas. MARIA ELIZABETH MORAES CAVALHEIROS DORVAL e VANIA LUTCIA BRANDAO NUNES, pela dedicação e apoio na preparação de meios para cultivo de amebas de vida liure.

A Dra. HELENA APPARECIDA dOS SANTOS LIMA PEREI $R A$, pela inestimāvel colaboração na confirmaçāo taxionỗ mica de organismos do fitoplâncton.

Ao Quimico ORLANDO BAZITO FILHO, pela boa von tade e compreensão que demonstrou na revisão dos dados bisico-quỉmicos.

A Farmacêutica Bioquímica PETRA SANCHEZ SANCHEZ, pela dedicação demonstrada quando o trabalho ainda se esboçava.

AOS Profs. JOAQUIM DIAS DA MOTA LONGO, EUGENIO OLIVEIRA MARTINS DE BARROS I MILTON MIRANDA SOARES, pela colaboração eficiente que em muito facilitou a elabora ção da presente tese. 
Ao Prof. ElIo CAPRIATA, pelo valioso auxilio no esboço do mapa da cidade de campo Grande.

A Médica REGINA SELBA DE MORAES, pelo apoio e auxilio na revisão do texto.

À Sra. ALZIRA PINOTTI BERTOLLAZZI, pela valio sa assistência na aquisição de referências bibliogrābicas.

Aos funcionários da Biblioteca da Faculdade de saūde püblica da universidade de são Paulo, em especial à sra. MARIA CECÍLIA GONZAGA FERREIRA, pelo interes se demonstrado na revisão bibliográfica.

As Sras. WILMA GARCIA DE SOUZA LOURENÇO e ILA DYR DA SILUA COMMERÇO, pelos serviços de datilografia.

Aos funcionārios da seção de pōs-Graduação da Faculdade de Saūde Püblica da Universidade de São Paulo, pela atenção.

A Coordenação do Aperfeiçoamento de Pessoal de Nivel Superior (CAPES), pelos subsidios concedidos através de bolsa de estudos, para colaboração na execução do presente trabalho. 
pàgina

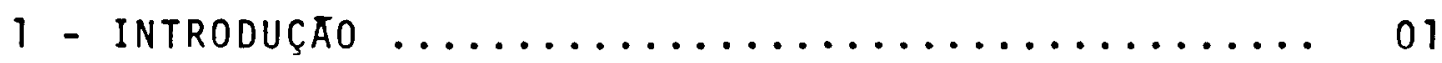

1.1 objetivos $\ldots \ldots \ldots \ldots \ldots \ldots \ldots \ldots \ldots \ldots \ldots \ldots \ldots \ldots$

2 - materiais e metodos ...................... 11

2.1 Seleção das piscinas $\ldots . . \ldots \ldots \ldots \ldots \ldots \ldots .11$

2.2 Caracterização das amostras $\ldots \ldots \ldots \ldots \ldots 13$

2.3 Parāmetros físico-químicos $\ldots \ldots \ldots \ldots \ldots, 14$

2.3.1 Temperatura ............... 14

2.3 .2 Turbidez ................... 14

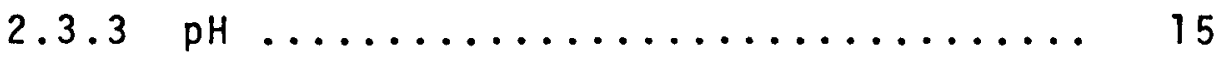

2.3 .4 cloro $\ldots \ldots \ldots \ldots \ldots \ldots \ldots \ldots \ldots, 15$

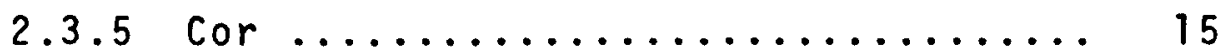

2.3 .6 Alcalinidade ................ 15

2.3 .7 Cloretos .................. 16

2.4 Indicadores biológicos $\ldots \ldots \ldots \ldots \ldots \ldots \ldots 16$

2.4.1 Bactērias ................. 16

2.4 .2 Leveduras $\ldots \ldots \ldots \ldots \ldots \ldots \ldots \ldots .20$

2.4 .3 Fitopiāncton $\ldots \ldots \ldots \ldots \ldots \ldots \ldots .24$

2.4.4 Amebas de vida livre ........... 25

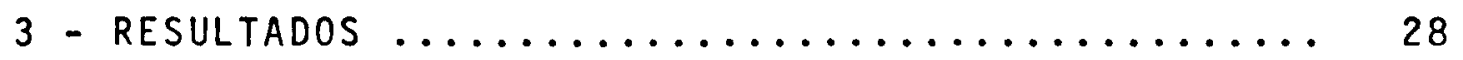

3.1 Caracterização das piscinas $\ldots \ldots \ldots \ldots \ldots 28$

3.2 Parāmetros físico-quỉmicos $\ldots \ldots \ldots \ldots \ldots .28$

3.3 Indicadores biológicos $\ldots \ldots \ldots \ldots \ldots \ldots, 28$ 
Pāginas

4 - DISCUSSÃO ........................ 30

4.1 Parämetros físico-químicos ............. 31

4.1 .1 Temperatura $\ldots \ldots \ldots \ldots \ldots \ldots \ldots \ldots$

4.1 .2 Turbidez $\ldots \ldots \ldots \ldots \ldots \ldots \ldots \ldots \ldots \ldots$

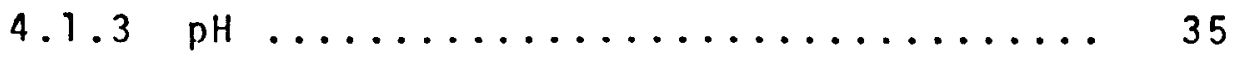

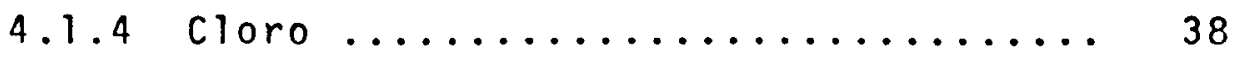

4.1 .5 Cor ........................ 42

4.1 .6 Alcalinidade .............. 43

4.1 .7 cioretos ................ 44

4.2 Indicadores biolögicos .............. 44

4.2 .1 Bactērias ................... 44

4.2 .2 Leveduras ................. 60

4.2 .3 Fitoplāncton $\ldots \ldots \ldots \ldots \ldots \ldots \ldots 6 . \ldots \ldots$

4.2.4 Amebas de vida livre .......... 71

5 - CONCLUSOES E RECOMENDAÇOES ................ 77

6 - REFERENCIAS BIBLIOGRAFICAS ............... 81

ANEXO I - Quadros de 1 a 12

ANEXO II - Tabelas de 1 a 6 
Levando em consideração que a piscina é um ele mento necessārio à saúde da comunidade e que a água, re servada nesses tanques, pode veicular agentes etiológi cos de doenças, procurou-se estudar as condições sanitā rias de piscinas de uso coletivo de Campo Grande, Mato Grosso do Sul, Brasil.

Com a finalidade de realizar anālises físicoquímicas e bacteriológicas, pesquisas de leveduras, al gas e amebas de vida livre, foram obtidas 336 amostras, em quatro coletas de cada piscina, durante o periodo de 09 de agosto de 1981 a 27 de junho de 1982. As amos tras foram coletadas da água e do raspado das paredes.

De modo geral, com base nos resultados consegui dos, constatou-se que as piscinas não mantēm os nĩveis de cloro suficientes à desinfecção. Em algumas foram registrados altos indices de bactérias, presença de al gas nas paredes, bem como a ocorrencia de leveduras e de amebas de vida livre potencialmente patogenicas. E im portante assinalar a presença destes protozoārios, face aos recentes registros de casos de meningoencefalite a eles associados.

Conclui-se que há necessidade de tratamento ade quado da āgua, treinamento especializado dos operadores e prática de princīpios bāsicos de educação em saúde. Recomenda-se o estabelecimento de legislação pertinente. 
Considering that a swimming pool is a necessary item for the public health and that the water in such pools may contain aetiological agents of diseases, we sought to study the sanitary conditions of public swimming pools in Campo Grande, Mato Grosso do Sul, Brazil.

With the objective of making physical-chemical and bacteriological analyses, yeast, algae and free-living amoebae researches, we obtained 336 samples in four samplings, from august 9,1981 to june 27,1982 . The samples were collected from the water and from the walls.

Generally, we observed that chlorine levels necessary for desinfection were not usually maintained in the swimming pools. In some of them high bacterial levels and algae on the walls were detected, as well as the ocurrence of yeast and potencially pathogenic free-living amoebae. It is important to focus the presence of these.protozoa on occount of the recent occurrence of primary amoebic meningoencephalitis cases.

In conclusion, there is the necessity of adequate treatment of the water, specialized training of the people who deal with it and the practice of the basic principles of health education. We recommend the stablishment of a legislation concerning this matter. 
1. INTRODUÇAO 
Os registros mais antigos evidenciam que o.s banhos de imersão tiveram inĩcio por recomendação de Iideres religiosos como Brahama, Buda, Zoroastro, Manu, Moisēs, Maomé e outros, que associaram o banho a atos de fé e purificação.

As piscinas, desde tempos remotos, passaram a ser usadas pelo homem, sendo inúmeros os relatos na civilização oriental e na ocidental greco-romana, on de a piscina aparece já inserida no contexto familiar ou associada aos banhos públicos.

Homero jā falava nas banheiras de Mykene, ainda hoje perfeitamente conservadas. Na cidade da Babi Iónia foi encontrada outra semelhante às de Mykene. Exis te ainda um vaso com gravura de piscina para mulheres, às margens de um rio, herdado da antiga civilização grega.

os mais antigos banhos públicos, dos quais se tem notícia, são os do Gināsio de Assos, na Ásia Me nor, usados com finalidades desportivas.

No século XIII, na Europa, havia banhos coletivos e em 1682, Jan Suyten, numa gravura em cobre, representou a piscina imperial de Aix-la-Chapelle.

No Japão as piscinas coletivas, para ba nhos sociais, vēm desde as primeiras dinastias.

os banhos püblicos, com aspecto semelhan te às piscinas atuais, ao que parece, tiveram início em Liverpool, por volta de 1842. A moda difundiu-se, passan do oito anos mais tarde à França e em 1855 as piscinas chegavam a Alemanha (ZINGANO, 1956) 97.

FORATTINI $(1975)^{37}$ ressalta que o hābito de natação e dos banhos coletivos propicia a reunião de 
indivĩduos de ambos os sexos e vārias idades, formando comunidades temporárias, as quais tem concorrido para difundir o uso das piscinas.

Realmente, neste século, as piscinas, à medida que as técnicas de controle sanitārio evoluiram, foram crescendo em nūmero, forma e tamanho, deixando de ser apenas um privilēgio dos lares de famílias abasta das para atender tambēm às populações produtivas e ca rentes. Por sinal, de acordo com o Professor Freitas e Castro, citado por ZINGANO $(1956)^{97}$, o controle sanitário de piscinas começou a ser efetuado ao iniciar-se a segunda metade da primeira década do século XX. Esse autor assinala que "a fiscalização sanitāria começou na Califörnia em 1917, quando o "State Board of Health" foi investido da autoridade necessária para intervir nesse assunto, fazendo cumprir o chamado "Califórnia Swimming Pool Act" que estabelecia as exigéncias necessārias pa ra salvaguardar a saūde pūblica. Em 1920 a fiscaliza ção estendeu-se por todos os estados da América do Nor te e logo depois generalizou-se em todo o territōrio".

Atualmente, em geral, qualquer pequena comunidade periférica, de zonas urbanas ou rurais, pos sui em seu clube ou no àmbito municipal uma piscina de uso coletivo.

OLIVEIRA $(1975)^{71}$ muito propriamente as sinala que a piscina se transformou em elemento necessá rio à saūde, à recreação e ao equilíbrio psico-fisioló gico, à disposição da comunidade. No entanto, segundo PERA $(1975)^{75}$, o homem usuário das piscinas é um animal terrestre e por isso, ao contrārio dos aquāticos, não dispõe da proteção que estes possuem contra o acesso da 
àgua ao trato respiratório, ao canal auditivo mucosas. Segundo HELMER $(1975)^{53}$ "parece, entre tanto, que as infecções dos olhos, dos ouvidos, do nariz e da garganta são mais frequentes entre pessoas que se banham em piscinas do que entre as que o fazem em àguas naturais". Esse mesmo autor relata ser preciso conside rar que a saūde do homem pode ser afetada não só pela ingestão de alimentos e äguas contaminadas, mas também pelo uso da àgua poluída, seja no asseio pessoal, seja na recreação.

Para a saūde pūblica, do ponto de vista epidemiológico, interessa conhecer os agravos a que uma comunidade de freqüentadores de piscinas pode estar su jeita (FORATTINI, 1975) 37 .

Historicamente, $\bar{e}$ importante mencionar, que o verdadeiro ponto de partida que serviu de base $\bar{a}$ elaboração de normas nacionais de proteção e manutenção da qualidade de àgua potāvel, segundo BRANCO $(1978)^{13}$, foi o periodo que medeia desde a descoberta dos micror ganismos por Leewenhoek, em 1683, até a suposição de Hen le e as constatações posteriores de Kock e Pasteur de que muitos seres microscōpicos eram causadores de enfer midades.

No entanto, conforme $\operatorname{RAMOS}(1970)^{78}$, a partir da observação clássica de John Snow em 1849, em seu elegante trabalho sobre a cōlera transmitida através da āgua, que maiores atençōes passaram a ser voltadas aos riscos de saūde associados à poluição e contamina ção das àguas.

As àguas destinadas principalmente à re creação de contato primārio (banho, mergulho, etc.) des 
pertaram maior interesse desde a década de 50 neste sécú 10, quando então as piscinas começaram a ser objeto de pesquisas, relacionadas principalmente ao aproveitamen to dos sistemas de recirculação da àgua e à desinfec ção.

No Brasil, talvez o grande impulso paraa manutenção da qualidade da āgua, visando manter os pa drões sanitārios de balneabilidade nas piscinas, tenha sido motivado pela expansão, a partir dos anos 60, da construção de grande número de piscinas não só em resí déncias particulares como também nos clubes destinadas à prātica desportiva e à recreação. Este fato levou ao aparecimento de um novo ramo de atividade lucrativa, ge rando a criação de firmas "especializadas", nem sempre capacitadas para o tratamento de águas de piscinas.

OLIVEIRA $(1975)^{71}$ ressalta que, em cer tos aspectos, a àgua reservada em uma piscina exige ama nutenção de alguns padrões, que deveriam ser mais acura dos que os normalmente recomendados para água potável des tinada ao abastecimento público. Aponta ainda o fato de que não só as condições sanitārias devem ser considera das, mas a limpidez da āgua, por exemplo, é também de grande importāncia para a própria segurança dos banhistas, no tocante à possibilidade de acidentes.

Dos riscos à saúde dos usuārios que even tualmente as piscinas podem oferecer, $\bar{e}$ preciso mencionar as doenças transmissiveis e as não transmissiveis, considerando nestes ūitimos os acidentes leves como con tusōes, ou deletérios como afogamento (SIMAO e col., $1977)^{87}$.

De acordo com SIMAO e col. $(1977)^{87}$, as 
doenças transmissiveis adquiridas em piscinas podem es tar associadas ao banho e também ao uso das instalações anexas como vestiārios, chuveiros, lavapés, etc.

Todavia, é a āgua considerada o principal veículo de disseminação dos agentes etiológicos das doenças associadas ao uso da piscina. Esse fato pode es tar relacionado com:

- a água de alimentação da piscina que jā vem poluída por não sofrer tratamento ou por ser tratada de modo precário;

- a água, tratada ou não, que é poluĩda pelo banhista (SOMOSI, 1981) 90 .

No primeiro caso, PERA $(1975)^{75}$ recomenda que o abastecimento de āgua destinada à alimentação das piscinas, independente de serem de alimentação continua, de reposição, ou de recirculação e tratamento, deva provir de um manancial (poços, fontes, rede púbí ca) satisfatório sob o ponto de vista químico, físico e bacteriológico.

Para salvaguarda da saūde do banhista é fundamental, portanto, a constante avaliação das condi ções sanitārias da àgua.

Nesse sentido vārios autores, dentre ou tros REINHARDT $(1977)^{79}$, ressaltam que o exame bacterio lógico possibilita conhecer as condições atuais de um corpo hidrico, enquanto que os exames físicos e químicos possibilitam a verificação da existēncia de poluição re mota.

As normas da Organização Mundial da Saú- 
de (OMS), como a maioria das normas vigentes para água potável, estão baseadas na pesquisa de organismos indi cadores de poluição fecal, como Escherichia coli e es treptococos fecais (GIROULT, 1977) 49.

0 ideal, principalmente em piscinas de uso coletivo, é que se proceda periodicamente o contro le sanitário realizando exames físico-químicos e bacte riológicos, concomitantemente.

Alēm das bactérias, outros organismos es tão sendo utilizados na avaliação da qualidade da água de piscinas e àguas recreacionais em geral.

Recentemente, tem-se dado atenção ao sig nificado ecológico dos fungos em ambientes aquāticos, procurando-se descobrir sua importāncia como organismos indicadores da qualidade da água e como patógenos huma nos. Assim, a associação entre concentrações de fungos em ambientes aquāticos e matéria orgānica sugere que fun gos possam ser indicadores de poluição. Apesar de que nenhuma espécie em particular ou grupo de fungos tenha sido ainda adotado como tal, alguns pesquisadores pro põem que certas espécies de leveduras possam ser utili zadas para caracterizar determinados tipos de poluição (AMERICAN PUBLIC HEALTH ASSOCIATION, 1980) ${ }^{2}$.

E frequente, em àguas de piscinas, o en contro de fungos potencialmente patogénicos ao homem. Entretanto, o significado desta via de transmissão na epidemiologia das micoses é ainda desconhecido. Dentre os grupos de fungos saprófitas capazes de causar doenças em individuos comprometidos, destacam-se as leveduras es pecialmente as do gēnero Candida, pelo acentuado carā ter oportunista. 
As algas também aqui devem ser considera das, pois são habitantes comuns de àguas pouco profundas (PALMER, 1962) ${ }^{73}$.

Os problemas originados pela proliferação de algas em águas de piscinas, em geral, são de or dem estētica. As āguas de piscinas quando contēm material nutritivo para algas (amōnia, fosfato, etc.) tornam-se opacas e de aspecto esverdeado ou às vezes avermelhado, dependendo do tipo de algas que nelas se desen volva. Trata-se na verdade de um fenōmeno de cor aparente, dada pela presença de organismos coloridos, em suspensão, que constituem o chamado pläncton (BRANCO e PEREIRA, 1975) 14.

Modernamente, as algas quando surgem em piscinas estão sendo consideradas, nos Estados Unidos, como indicadoras das más condições de tratamento (MONTEI RO, 1984$)^{\star}$.

Outra tendéncia atual é a da verificação da possivel presença de amebas de vida livre em àguas de piscinas, por sua potencialidade patogênica e também por ser a água uma das principais vias de transmissão.

Em 1965, na Austrālia, foram descritos os primeiros casos humanos de uma nova entidade clinica, Meningoencefalite Amebiana Primāria (MAP), de evolução rápida e fatal, cujos agentes etiológicos são amebas do gēnero Naegleria, notadamente $N$. fowleri (FOWLER e CAR TER, 1965) 41 .

Outras amebas de vida livre, como as do gènero Acanthamoeba, são também consideradas como poten

* Informação pessoal do Enge Celso Eufrásio Monteiro da CETESB. 
cialmente patogênicas, causando Encefalite Amebiana Gra nulomatosa (EAG), também de evolução fatal, e outras a fecções como gastrites, uretrites, otites e ūlceras de córnea. Os casos de acantamebíase, em geral, estão na dependência do estado imunitário do paciente.

A dispersão das amebas de vida livre é extremamente ampla. Casos humanos de infecções relacio nadas a este grupo de protozoārios foram relatados em todos os continentes e em todas as latitudes. A transmissão, principalmente de espécies de Naegleria, ē atra vēs de coleções de àgua, como piscinas e lagos. Especialmente para $N$. fowleri, a temperatura elevada da água assume grande importância na multiplicação das formas trofozoíticas. A transmissão das espécies de Acanthamo eba pode não ser necessariamente por coleções de água. o ar e o solo tambēm podem carrear formas císticas das amebas.

Até o momento, hà cerca de 150 relatos de casos fatais de infecção por amebas de vida livre (GRIE FIN, $1977^{50}$; CULBERTSON, $1981^{26}$; MARTINEZ, $1983^{62}$ ).

\section{1 - Objetivos}

Alguns autores preconizam que "só se deve nadar em àgua potável", mas o fato real no Brạ sil $\bar{e}$ que apenas alguns Estados possuem regulamen tação criteriosa inserida em Lei, estabelecendo normas para o uso de piscinas.

Acredita-se, pois, ser este um motivo su ficiente para a realização do presente trabalho que se reveste de importāncia no que diz respeito à 
saúde pūblica.

Assim, ao se planejar esta pesquisa, te ve-se como objetivos:

- avaliar a qualidade sanitária de sete piscinas da cidade de Campo Grande, Mato Grosso do Sul;

- alertar para a necessidade de haver nas pisci nas operadores com cursos de tratamento de àgua de piscina;

- evidenciar a importāncia da educação em saūde, não só dos usuārios, mas também dos operadores e responsāveis administrativos das piscinas;

- ressaltar a necessidade do monitoramento físicoquímico e microbiológico para manutençao da qua lidade sanitāria das āguas de piscinas. 
2. MATERIAIS E METODOS 


\subsection{Seleção das piscinas}

Das dezessete piscinas de uso coletivo, da cidade de Campo Grande, Mato Grosso do Sul, de finidas conforme DECRETO no $12.342^{27}$, de 27 de se tembro de 1978, foram selecionadas sete piscinas. Tentou-se abranger as regiões centro, norte, sul e oeste da zona urbana e leste da periferia da cida de.

Por acordo efetivado com os responsáveis desses logradouros públicos, não serão aqui declí nados os nomes dos mesmos, utilizando-se apenas as siglas: A (zona oeste), B (centro), C e D (zona les te), $E$ e $G$ (zona sul) e $F$ (zona norte)*.

Procurou-se classificar as piscinas se gundo DECRETO no $12.342^{27}$, de 27 de setembro de 1978, como pode ser verificado pelo Quadro no 01 , do anexo I.

No que se refere ao tratamento, nas pis cinas pesquisadas, são utilizados praticamente os mesmos produtos empregados, em geral, no tratamen to da àgua destinada ao abastecimento público. A relação desses produtos estā inserida no Quadro no 02 , do anexo I.

A situação geogrāfica das piscinas estā representada na figura nọ 01 a seguir.

* Em decorrência deste trabalho serão efetivadas reco mendações a serem entregues aos administradores das piscinas. 
FIGURA - OI

CAMPO GRANDE- MATO GROSSO

DO SUL

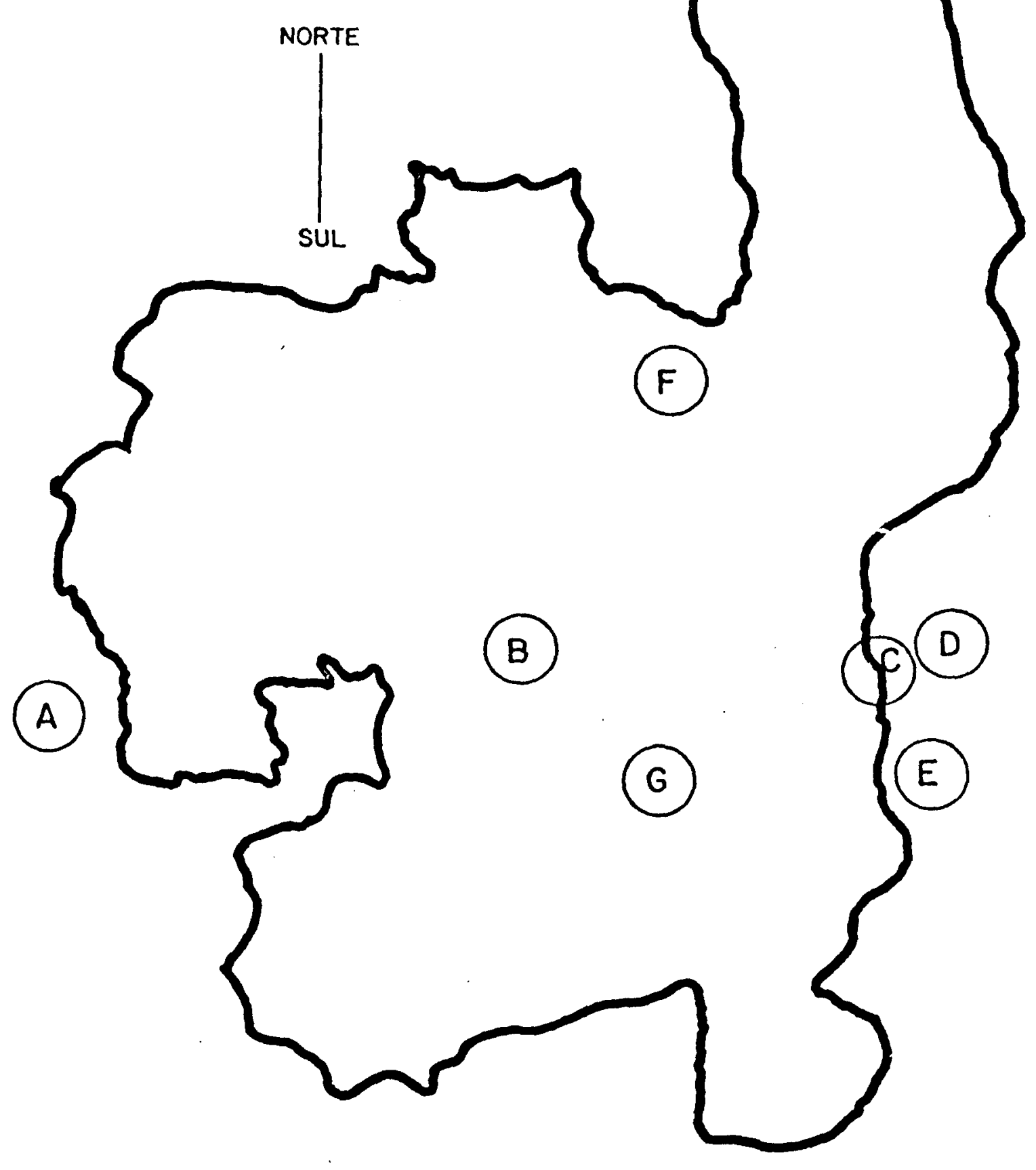




\subsection{Caracterização das amostras}

No planejamento das amostras foram leva dos em consideração a exigüidade dos recursos labo ratoriais, a dificuldade de transporte e o pequeno intervalo de tempo entre as coletas.

As amostras, em geral, foram coletadas em dois pontos, demarcados em função da maior ou menor concentração de banhistas nesses determinados 10 cais das piscinas. Procurou-se localizar os pon tos de tal forma que o de nọ 01 coincidisse com a parte rasa, onde a freqüencia quase sempre é maior, e o de no 02 com a parte funda do tanque.

De 09 de agosto de 1981 a 27 de junho de 1982, foram realizadas quatro coletas em cada pis cina, num total de vinte oito no periodo, com inter valos de aproximadamente trinta dias. A escolna do dia da coleta foi feita em função da frequéncia às piscinas (domingo).

Foram coletadas amostras da água e do ras pado das paredes. As da āgua foram coletadas a uma profundidade de aproximadamente $0,30 \mathrm{~m}$ da superfi cie, tomando-se as devidas precauções para evitar contaminação. 0 total de amostras foi de trezentos e trinta e seis, assim distribuídas:

- 28 para anālises físico-químicas;

- 28 para anālises bacteriológicas;

- 56 para pesquisas de leveduras;

- 112 para pesquisas de algas;

- 112 para pesquisas de amebas de vida livre. 
A técnica de amostragem desenvolvida foi a mesma utilizada pela Companhia de Tecnologia e Saneamento Ambiental - CETESB (SOUZA e DERISIO, $1982)^{91}$.

\subsection{Parāmetros físico-químicos}

A seleção dos parāmetros físico-químicos foi feita segundo O DECRETO no $12.486^{27}$, de 20 de outubro de 1978, que aprova a Norma Técnica de Água (NTA-60), para consumo humano, do Estado de São Pau 10 .

Foram utilizados os seguintes parâmetros: temperatura, turbidez, $\mathrm{pH}$, cloro residual, cor, al calinidade, acidez e cloretos.

As anāilises foram baseadas em "Standard methods for examination of water and wastewater, $(1980)^{2}$

\subsubsection{Temperatura}

Para medir a temperatura do ar e da āgua, foi utilizado um termómetro de mercūrio com escala de $-30 a+500 C$.

\subsubsection{Turbidez}

Para a avaliação da turbidez foi adotado - método nefelométrico, tendo sido utilizado o tur bidímetro marca HACH, tendo como padrão de turbidez 10 UNT. 


\section{$2.3 .3 \mathrm{pH}$}

A verificação do $\mathrm{pH}$ foi realizada por meio de aparelho comparador colorimétrico, tendo sido usado como indicador o vermelho-fenol e o equi pamento utilizado foi do tipo "Genkit", tendo uma faixa de leitura de $\mathrm{pH}$ compreendida entre 6,6 e 8,2.

\subsubsection{Cloro}

A determinação da presença de cloro na ăgua foi realizada utilizando-se um comparador co lorimētrico marca "Hellige", com disco de cloro de leitura de 0,0 a $1,0 \mathrm{mg} / 1$, usando-se como reagente indicador uma solução àcida de ortotoluidina (méto do OTA - colorimetria com disco).

\section{3 .5 Cor}

O método usado foi o da comparação visu a 1, através de disco para cor, tipo "Acqua Tester", com faixa de 0,0 a $50,0 \mathrm{mg} / 1 \mathrm{Pt}$ (padrão de cloropla tino cobalto).

\subsubsection{Alcalinidade}

A alcalinidade foi determinada pelo méto do de titulação colorimétrico, utilizando-se solú ção de Fenolftaleína como indicador de meio bāsico e Metilorange de meio ācido, sendo o àcido sulfúrí co $N / 50$ usado como titulador para viragem de colo ração. 


\subsubsection{Cloretos}

A anālise de cloretos foi realizada uti lizando-se o método de Nitrato de Prata.

\subsection{Indicadores Biológicos}

Na caracterização da qualidade sanitāria da àgua, procurou-se identificar a presença de mi crorganismos e sua eventual importāncia na àgua uti lizada na recreação de contato primário.

Neste trabalho foi feita a contagem pa drão de colónias de bactérias, pesquisa de Pseudo monas aeruginosa, estreptococos fecais e bactérias do grupo coliforme.

Os outros organismos pesquisados não são ainda empregados como indicadores de poluição, não se tendo conhecimento de que os mesmos tenham sido utilizados como padrões de potabilidade da àgua de piscinas. Todavia dada a importāncia sanitária, tentou-se a identificação, sendo este o caso das le veduras, amebas de vida livre e algas.

\subsubsection{Bactérias}

As amostras de àgua foram coletadas utị lizando-se frascos de vidro neutro, com capacidade para $250 \mathrm{ml}$, boca larga e tampa esmerilhada, aos quais foram adicionados $0,1 \mathrm{ml}$ de solução de tiosul fato de sódio a 10\% para cada $100 \mathrm{ml}$ da amostra, seguindo-se o procedimento de esterilização. As 
amostras foram conservadas sob refrigeração (4 a $100 \mathrm{C}$ ) até o início do exame, nunca excedendo o tem po limite de 24 horas.

As anāilises bacteriológicas foram reali zadas segundo "Standard methods for the examination of water and wastewater" $(1980)^{2}$ e Normalização Téc nica da Companhia de Tecnologia de Saneamento Ambi ental - CETESB números $L 5.202^{68}$ (Determinação do número mais provável de coliformes totais e fecais pela técnica dos tubos mūitiplos); L5.20569 (Deter minação do NMP de Estreptococos fecais pela técni ca dos tubos mūitiplos); L5.22070 (Determinação do NMP de Pseudomonas aeruginosa pela técnica dos tú bos mūitiplos) e $L 5.201^{67}$ (Contagem padrão de colō nias de bactérias.

\subsubsection{Determinação de coliformes}

Foram realizadas pesquisas de bactérias do grupo coliforme e de coliformes de origem fecal. Volumes decrescentes $(10,0 ; 1,0$ e $0,1 \mathrm{ml})$ de cada amostra foram inoculados em séries de cin co tubos, sendo que para bactérias do grupo colifor me os exames foram realizados através de duas eta pas:

1. Teste Presuntivo: consistiu na semea dura de volumes determinados da amostra em caldo lactosado, os quais foram incubados a $350 \mathrm{C}$, sendo a primeira leitura com 24 horas e a leitura final com 48 horas. 
2. Teste Confirmativo: a partir de cada tubo com teste presuntivo positivo, foi realizado o teste confirmativo, transferindo-se com uma alça de platina um volume da cultura para um tubo corres pondente de caldo lactosado verde brilhante bile a $2 \%$ e incubados em estufa a $350^{\circ} \mathrm{C}$ por 48 horas.

0 teste para diferenciação de coliformes fecais consistiu na transferēncia das culturas com resultados positivos no caldo lactosado (teste pre suntivo) para tubos contendo meio de "EC" que foram incubados durante 24 horas a $44,50 \mathrm{C}$ em banho-maria.

os resultados foram considerados positi vos quando havia produção de gās (nos tubos de fer mentação) a partir da fermentação da lactose con tida nos meios de cultura.

\subsubsection{Determinação de estreptococos fecais}

$\mathrm{Na}$ pesquisa de estreptococos fecais foram usados volumes de 10,$0 ; 1,0$ e $0,1 \mathrm{ml}$, sendo que ca da porção da amostra foi inoculada numa série de cinco tubos. 0 exame foi processado através de du as fases:

1. Exame Presuntivo: consistiu em semear os volumes determinados da amostra da àgua em tú bos contendo caldo destrose azida e incubados em estufa durante 24 - 48 horas a $350^{\circ} \mathrm{C}$. Na presença de turvação do meio de cultura, o ensaio foi consi derado positivo. 
2. Ensaio Confirmativo: a partir de ca da tubo com ensaio presuntivo positivo, foi feita a transferéncia da cultura para tubos contendo cal do azida etil violeta e incubados durante $24-48$ horas a $350 \mathrm{C}$. A presença de estreptococos fecais foi indicada pela formação de precipitado arroxea do no fundo do tubo.

\subsubsection{Determinação de Pseudomonas aeruginosa}

A determinação do NMP de Pseudomonas aeru彑 ginosa foi feita a partir da técnica dos tubos mú tiplos, com diluições sucessivas de 10,$0 ; 1,0$ e 0,1 ml, sendo que cada volume foi inoculado em séries de cinco tubos. 0 exame foi processado através de trēs etapas:

1. Teste Presuntivo: consistiu em semear os volumes determinados das amostras em tubos de caldo asparagina e incubados a $350 \mathrm{C}$, com leituras a cada 24 horas. Foi considerada prova presuntiva positiva a observação de fluorescēncia sob luz ne gra.

2. Teste Confirmativo: consistiu na trans ferēncia das culturas positivas de cada leitura pa ra tubos contendo caldo acetamida. As provas fo ram consideradas com resultados positivos pela evi denciação de coloração pūrpura do meio. As leitú ras foram feitas a cada 24 horas, totalizando 96 horas de incubação. 
Teste Completo: consistiu em isolar as culturas com resultados positivos no caldo acetami da, em placas de āgar leite, conforme BROWN e FOS TER $(1970)^{16}$. Foram consideradas positivas as pro vas que mostravam colónias com halo claro devido a hidrólise da caseína.

\subsubsection{Contagem padrão de colōnias de bactérias}

A determinação da densidade de bactérias das amostras de āgua das piscinas foi definida, ino culando-se volumes da amostra de 1,0 e $0,1 \mathrm{ml}$ em placas de Petri, adicionando-se a seguir triptona glicose extrato de levedura ( $p l a t e$ count agar), as quais foram incubadas a $350 \mathrm{C}$ durante 24 horas. A contagem das colónias foi feita com o auxilio de um contador tipo "Quebec".

\subsubsection{Leveduras}

Para o isolamento e identificação de le veduras em āgua não existe padronização, sendo re comendados alguns meios mais apropriados para o crescimento de leveduras em detrimento dos bolores.

Para a classificação taxionōmica de leve duras foi utilizada a monografia de LODDER (1970) ${ }^{58}$.

os caracteres morfológicos e fisiológicos foram utilizados para a classificação genérica. A identificação a nível de espēcie, conseguida em a I guns casos, foi baseada em caracteres bioquímicos, a lēm dos acima citados. 
As amostras foram coletadas assepticamen te em frascos de $1000 \mathrm{ml}$. Os frascos foram acondi cionados em recipientes fechados de isopor, com ge 10, chegando ao laboratório após 20 a 30 horas do momento da coleta. No laboratōrio do Instituto Adolfo Lutz de São Paulo as amostras foram proces sadas imediatamente após a entrada na Instituição.

\subsubsection{Isolamento das leveduras}

Para o processamento das amostras de $\underline{a}$ gua utilizou-se câmara de fluxo laminar, onde fo ram semeadas alíquotas de 0,2 e $0,5 \mathrm{ml}$ de água, na superfície de meios sōlidos, distribuídos em pla cas de Petri. Para cada volume de amostra foram utilizados dois tipos de meios de cultura para iso lamento: ágar malte com $0,1 \%$ de extrato de levedu ra e cloranfenicol (MLC) e ágar Sabouraud com clo ranfenicol e cicloheximida (SCC). A incubação foi feita a $250 \mathrm{C}$ por período de 5 a 30 dias. Todas as alíquotas foram trabalhadas em duplicata.

Com auxílio de estereomicroscópio (usan do-se aumento de $400 \mathrm{X}$ ) foram isolados tipos dife rentes de colōnias e repicadas em āgar malte.

\subsubsection{Caracteristicas morfolögicas}

Os caracteres macromorfológicos observa dos nas colónias isoladas foram: cor, forma, textu ra e brilho da superfície. A morfologia da célula vegetativa foi descrita a partir de culturas de 5 
a 24 dias em meio de malte com $0,1 \%$ de extrato de levedura, líquido e sólido. A presença de cápsula foi tambēm verificado nesse meio.

A formação de micēlio verdadeiro e pseu domicēlio foi verificada a partir de cultivo em la a mina com àgar farinha de milho, segundo tēcnica des crita por RIVALIER e SEYDEL $(1932)^{\circ 1}$, após 10 dias de crescimento.

A formação de esporos sexuais foi testa da usando-se os meios de āgar suco $V-8$, āgar aceta to de Fowell, āgar de Gorodkowa e àgua destilada, e a temperatura de incubação foi de $250^{\circ} \mathrm{C}$ por seis semanas. Para a evidenciação dos esporos foram uti lizadas duas técnicas de coloração, a de Wirtz, cí tada por LODDER $(1970)^{58}$ e a de Dorner modificada, BIER (1978) $)^{9}$. Balistosporos foram pesquisados se gundo a técnica descrita por LODDER $(1970)^{58}$. 0 crescimento em meio de Sabouraud líquido foi obser vado quanto à formação de película, anel ou sedimen to no terceiro e vigésimo primeiro dias a $250 \mathrm{C}$.

\subsubsection{Características bioquímicas e fisiológicas}

Para os testes de fermentação foram dís tribuídos volumes de $2 \mathrm{ml}$ de meio básico (peptona $0,75 \%$ e extrato de levedura $0,45 \%$ ) em tubos de en saio de $12 \mathrm{~mm} \times 120 \mathrm{~mm}$, tendo em seu interior tú bos de Durham invertidos. Apōs a esterilização em autoclave a $121^{\circ} \mathrm{C}$, durante 15 minutos, foi adicio nado a cada tubo $1 \mathrm{ml}$ de açūcar a $6 \%$, esterilizado por tindalização. A série de carboidratos emprega 
da inclui glicose, lactose, maltose, sacarose e trealose. Os testes de fermentação foram feitos com culturas novas crescidas em āgar MLC. A leitu ra foi feita diariamente nos primeiros cinco dias, depois de dois em dois dias, até trinta dias de in cubação. 0 resultado da fermentação foi considera do positivo quando houve produção de gās. As leitu ras foram anotadas como 1 + (uma ou poucas bolhas de gās); 2 + (para $2 / 3$ do tubo de Durham com gās); e 3 + (para o tubo de Durham cheio de gás).

Nas provas de assimilação de fontes de carbono em meio sōlido foram empregados os seguin tes compostos: glicose, galactose, maltose, sacaro se, celobiose, lactose, rafinose, xilose e inosi tol. Foi utilizado o método auxanogräfico descri to por Van der Walt, LODDER $(1970)^{58}$. Os halos de crescimento eram observados após o segundo, quinto e sétimo dias apōs a incubação a $250 \mathrm{C}$.

A prova de assimilação de nitrato foi rea lizada em meios de cultura līquido, segundo técnị ca descrita por Wickerham, 1951 (citado por LODDER, $1970)^{58}$ e apōs incubação a $25^{\circ} \mathrm{C}$ por quinze dias, as leituras foram anotadas como negativa, fraca e po sitiva, de acordo com recomendação do autor.

A prova para observação de produção de àcido foi realizada em meio contendo carbonato de cálcio, LODDER $(1970)^{58}$ e a leitura efetuada apōs a primeira, segunda e terceira semanas a $250 \mathrm{C}$. A formação de um halo claro grande foi considerada prova positiva; halo pequeno, fracamente positiva e meio de cultura inalterado, prova negativa. 
A produção de compostos semelhantes ao amido foi evidenciada com a adição de solução de iodo (Lugol 1/10) às placas de assimilação de gli cose, resultando em coloração azulada apōs 24 họ ras à temperatura ambiente.

A hidrōlise da urēia foi testada em meio líquido, seguindo-se a técnica recomendada por CHRISTENSEN $(1946)^{22}$.

Nos testes de resistência à cicloheximida, foi usado como meio base o āgar Sabouraud.

\subsubsection{Fitoplāncton}

As amostras de āgua para anāilise do fito plāncton foram coletadas utilizando-se frascos de vidro neutro, boca larga e tampa de borracha, com capacidade para $1000 \mathrm{ml}$.

os frascos não foram completamente cheios, a fim de manter uma pequena quantidade de ar sobre a superficie das amostras.

Um volume de aproximadamente $120 \mathrm{ml}$ de água, de cada amostra, foi centrifugado a 3000 r.p.m. durante quinze minutos.

0 fitoplāncton foi identificado utilizan do-se a cámara de Sedgwick-Rafter, conforme BRANCO $(1978)^{13}$.

0 raspado das paredes foi coletado com 0 auxílio de uma espátula de madeira, em seguida co locado em tubos de ensaio previamente esteriliza dos, mantendo-se sempre o material submerso na prō pria àgua da piscina e conservado sob refrigeração 
até o momento do exame, no māximo até cinco horas após a coleta. Foi feito exame direto do material, entre lãmina e lamínula.

Tanto a àgua como o raspado foram obser vados ao microscōpio óptico, com iluminação comum, usando aumentos lineares de $400 \mathrm{X}$.

Para a identificação dos organismos fo ram utilizadas as chaves de BICUDO e BICUDO (1970), BOURRELLY $(1966)^{12}$, PRESCOTT $(1962)^{77}$, SMITH $(1950)^{99}$. Quanto aos aspectos sanitários, foram se guidos os sistemas de BRANCO e col. (1963) 15, PAL MER e INGRAM $(1955)^{74}$.

\subsubsection{Amebas de vida livre}

0 material para pesquisa de amebas de $\mathbf{v} \underline{i}$ da livre foi coletado da àgua, com pipeta graduada ( $5 \mathrm{ml}$ ), e do raspado das paredes das piscinas com espātula de madeira e semeado em tubos de ensaio contendo meio āgar infusão de soja, segundo FORONDA $(1979)^{39}$. Os tubos foram mantidos $\bar{a}$ temperatú ra ambiente e enviados ao Instituto de Ciēncias Bio médicas - Departamento de Parasitologia da Universidade de São Paulo.

A metodologia da pesquisa de amebas de vida livre sofreu modificaçōes em face dos resultạ dos obtidos. De início, o material dos tubos era examinado diretamente, se positivo, semeado em pla cas de Petri contendo o mesmo tipo de meio de cul tura. Estas placas eram mantidas a $280^{\circ} \mathrm{C}$ examina das diariamente, sem abertura, para verificar ocres 
cimento das amebas. Em caso positivo, eram lava das com água destilada estéril e o material obtido examinado diretamente entre lámina e lamínula e em preparaçōes de gota pendente, para prova de flage lação, segundo técnica de PAGE (1976) 72 . Os tubos com resultados negativos eram ainda mantidos a $280^{\circ} \mathrm{C}$ e examinados semanalmente, durante dois meses.

A partir da terceira remessa o material de todos os tubos, tão logo ao chegar, era semeado em placas de Petri, seguindo a metodologia como des crita acima. Em muitos casos, o teste de flagela ção foi repetido uma ou mais vezes, para confirmar a positividade ou para novo teste das amebas da fa milia Vahlkampfiidae. Os padrões usados na identi ficação foram os de PAGE $(1976)^{72}$.

0 material foi trabalhado em cāmara assēp tica e as placas foram mantidas em sacos plasticos, para evitar a dessecação. Foram feitas projeções em cāmara clara e coloração por hematoxilina férri ca quando se fazia necessārio.

A observação das amebas no material a fresco foi feita em microscōpio de contraste de fá se, usando-se aumentos lineares de 100 e de $400 \times$ e no material corado sob aumento linear de $1000 \mathrm{X}$. 
3. RESULTADOS 


\subsection{Caracterização das piscinas}

Na caracterização das piscinas foi leva do em consideração a origem da āgua utilizada para alimentação das mesmas, posto que esta variāvel é de fundamental importāncia para a realização do tra tamento, bem como para a verificação da qualidade sanitāria da àgua, conforme pode ser evidenciado no Quadro No 03, do anexo I.

\subsection{Parāmetros físico-químicos}

Os resultados dos exames físico-químicos das amostras coletadas nos pontos de NQ 01 e 02 nas piscinas A (oeste), B (centro), C e D (leste), E e $G$ (sul) e F (norte) encontram-se na Tabela NQ 01 , anexo II.

\subsection{Indicadores biológicos}

Pelo Quadro No 05, anexo I e Tabelas de Nos. 02 e 03, do anexo II, pode-se fazer a anālise dos resultados bacteriológicos (NMP/l00 ml de coli formes totais e fecais, estreptococos fecais e Pse $\underline{u}$ domonas aeruginosa). A contagem padrão de bactéri as estā inserida no Quadro NQ 05 e Tabela NQ 02.

Em relação às leveduras, algas e amebas de vida livre, pode-se observar os resultados nas Tabelas de NQs. 04, 05 e 06, anexo II, respectiva mente e nos Quadros de NQS. 06 a 12, do anexo I. 
4. DISCUSSÃO 
No planejamneto do presente trabalho tevese, além de outros, o cuidado de escolher piscinas alimenta das por āgua de diferentes tipos de mananciais. 0 conheci mento da origem da água de alimentação é de fundamental im portāncia, principalmente no que se refere ao tratamento da àgua.

Não existindo em Campo Grande piscinas aque cidas de uso coletivo, todas as pesquisadas eram ao ar $1 \mathbf{i}$ vre e com temperatura natural da àgua. As piscinas, em sua maioria, possuiam revestimento de azulezos, com exceção da C que era de resina sintética. Quanto ao tratamento, foram classificadas como de "recirculação e tratamento" cinco pís cinas, $A, B, D, E, G$ e de "encher e esvaziar" duas, $C$ e F, as quais não possuiam sistema de filtração. A recirculação da piscina $D$ era realizada atravēs de sistema externo de bombeamento, não passando a āgua através de filtros.

0 tratamento de todas as piscinas pesquisa das era realizado por operadores, sem formaçāo técnica em cursos especializados. Segundo BLACK e col. (1970)11, é de grande importāncia que o tratamento seja correto, portanto, os operadores devem ter um minnimo de qualificação.

E interessante ser evidenciado que houve chu vas nas 24 horas anteriores às coletas das piscinas $A$ e $B$ (janeiro); C, D, E (agosto, fevereiro); F e G (dezembro, março). E também importante enfatizar que, no més de dezem bro, a chuva ocasionou penetração de água de enxurrada na piscina $F$, o que deve ter contribuido para carrear partícu las e microrganismos para o interior da piscina. Nas coletas das piscinas $F$ e $G$ efetuadas no més de dezembro, os ventos foram mais intensos do que nos outros meses, como se perce beu durante o trabalho de campo. 
Quanto à existência de banhistas, esta só foi verificada nas piscinas $A$ e B (janeiro); C, D, E (novem bro); G (dezembro), fator que pode influir tanto nos parāme tros físico-químicos como nos indicadores biológicos.

Como foi assinaldo, este trabalho objetiva principalmente verificar a qualidade sanitāria das āguas de piscinas, não sendo, portanto, estudadas as instalações ane xas que fazem parte das mesmas.

o estudo da qualidade da àgua estā baseado no número mais provāvel (NMP) de coliformes totais, colifor mes fecais (Escherichia coli), estreptococos fecais e Preu domonas aeruginosa. Paralelamente procurou-se verificar a presença de leveduras para complementar a caracterização da qualidade da àgua. 0 estudo das algas visou conhecer prin cipalmente as condições de tratamento da àgua. Jā as ame bas de vida livre foram estudadas tendo como precípuo inte resse o risco potencial para a saúde dos banhistas.

\subsection{Parâmetros físico-químicos:}

\subsubsection{Temperatura}

A temperatura da āgua è fator importante no tratamento, tanto pela influēncia direta que pode exercer sobre os organismos, como por sua relação com a solubilidade dos gases e sais e pela interferéncia na viscosidade da āgua (ROCHA, 1972) ${ }^{\circ}$.

Quando a temperatura da āgua estā acima de $25^{\circ} \mathrm{C}$ facilita a dissolução de sais e de gases, o que contribui para a elevação do pH (WATER, 1978) 96. 
Segundo BRANCO $(1978)^{13}$, "Os efeitos da po luição tērmica num corpo d'água podem ser diretos pe la coagulação das proteĩnas que constituem a matéria viva, ou indiretos, seja através de um aumento da capacidade tóxica de certas substāncias que se encon tram dissolvidas na āgua, como a rotenona, etc., ou por propiciar a proliferação de organismos concorren tes (parasitas), seja pela diminuição que a tempera tura provoca na capacidade da àgua de dissolver e ré ter oxigénio, ao mesmo tempo que aumenta a atividade fisiológica dos organismos aquáticos, condicionando asfixia dos mesmos".

A temperatura deve ser considerada em āguas de piscinas, principalmente, pela influéncia que tem nas alterações de $\mathrm{pH}$ na manutenção do residual de clo ro.

A elevação da temperatura da āgua pode conco mitantemente levar ao aumento do número de bactérias. Por exemplo, Pseudomonas aeruginosa multiplica-se ra pidamente se a àgua estiver aquecida (SOMOSI, 1981) ${ }^{90}$.

A manutenção da temperatura elevada da āgua favorece a evolução da espēcie patogēnica Naegzeria fowleri (DE JONCKHEERE e VAN DE VOORDE, 1977) $)^{\circ}$.

Durante a realização desta pesquisa foi ob servado que a temperatura da ägua variou de 19 a $28^{\circ} \mathrm{C}$ e a do ar de 18 a $35^{\circ} \mathrm{C}$, conforme Grä́fico No 01 a se guir apresentando, elaborado a partir da Tabela No 01 , do anexo II.

0 estudo das sete piscinas foi realizado pro curando-se perfazer um total de quatro coletas para cada uma, num período de onze meses. Observou-se com 


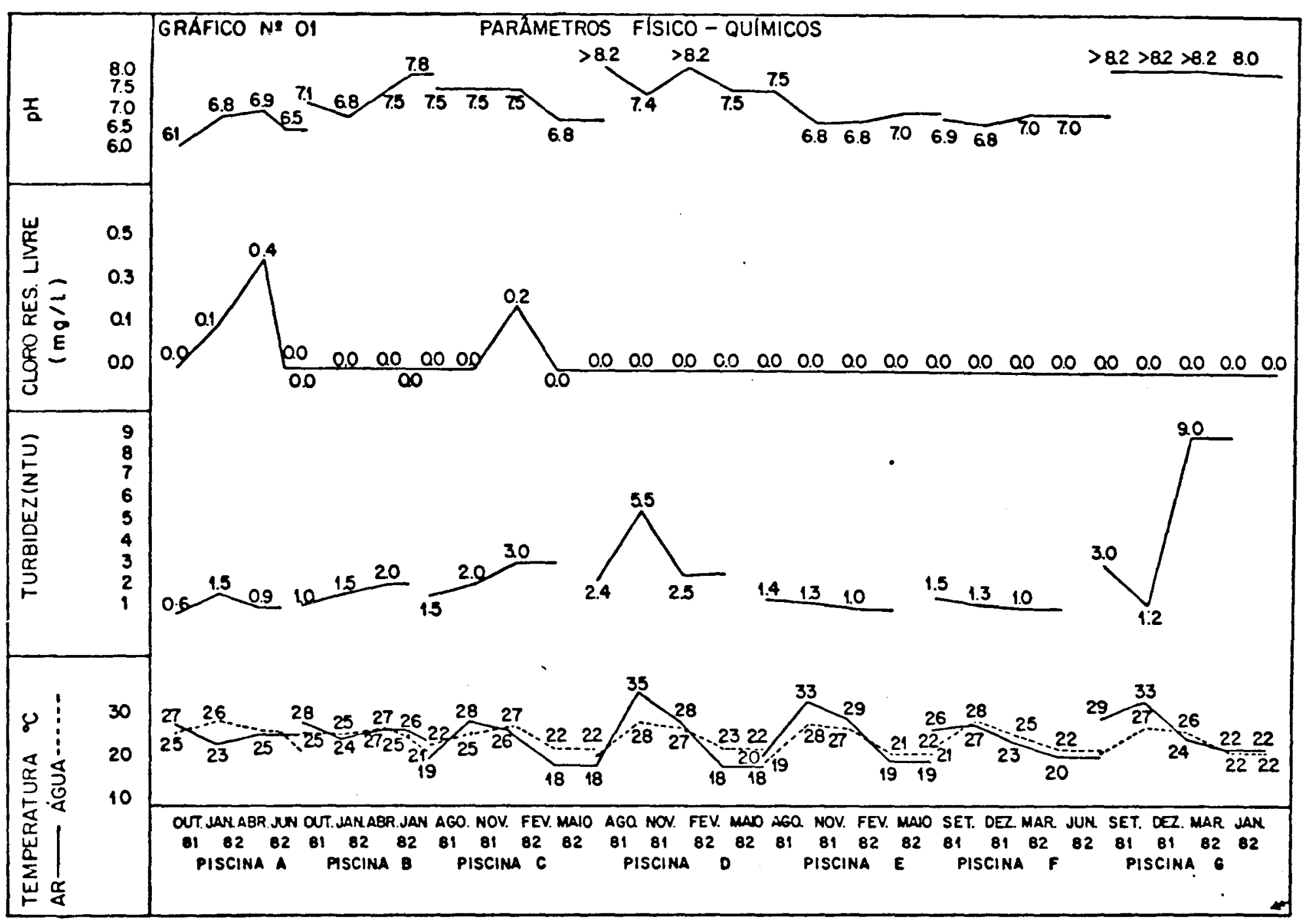


este estudo que provavelmente devido às constantes frentes frias oriundas dos Andes, nem sempre, na re gião estudada, os meses mais frios correspondem ao inverno e os mais quentes ao verão. Foi notada tam bēm uma certa inversão de temperatura do ar e da água, que pode estar relacionada ao tempo encoberto e mui tas vezes com pequenas precipitações e muito vento.

Outro aspecto, que foi evidenciado da anāl se do Gräfico Nọ 01, anteriormente apresentado, quan to a temperatura do ar, é que o seu aumento contri bue consideravelmente para elevar o nümero de banhis tas, que podem proporcionar o aumento, na água, de microrganismos, cloretos, amōnia, alēm de contribuir para maior demanda do cloro residual.

\subsubsection{Turbidez}

Como a legislação não prevē os limites de tur bidez para àgua de piscina, foi adotado o indice pre conizado de 2-5 NTU, para āgua de consumo humano, con forme DECRETO No $14.486^{28}$, de 20 de outubro de 1978, que aprova a Norma Técnica de Agua (NTA-60) do Esta do de São Paulo.

Tomando-se por base essas normas, foi obser vado que āguas de piscinas com turbidez abaixo do $1 \underline{\mathbf{i}}$ mite minimo oferecem menores oportunidades para uma concentração bacteriana e melhores condições para a cloração (GELDREICH, 1974$)^{46}$.

"A turbidez acima de 0,5 unidade pode ser percebida pela luz difusa num ambiente escuro, estan do a amostra num cadinho muito limpo, e usando um 
feixe luminoso ou fonte similar. Turbidez inferior a 0,1 unidade pode ser obtida pelo tratamento da āgua" (BABBIT e col., 1962) ${ }^{7}$.

os valores de turbidez permitem avaliar se os filtros, "alma do sistema", estão sendo bem opera dos e mantidos (CETESB, 1983$)^{24}$.

Das piscinas pesquisadas (Grafico No 01 , in serido no item 4.1.1, Tabela No 01, anexo II) a $D$, no més de novembro, apresentou turbidez igual a 5,5 NTU, quando foi observada a presença de banhistas. As algas não devem ter contribuido para a elevação da turbidez, pois não foram detectadas nessa amostra de àgua.

As outras piscinas apresentaram-se dentrodos limites estabelecidos.

$4.1 .3 \mathrm{pH}$

A verificação do $\mathrm{pH} \bar{e}$ de grande importância, principalmente para se ter um adequado controle do equilíbrio acidez-alcalinidade, por vārias razōes: a alcalinidade da àgua é essencial à hidrōlise do sulfá to de aluminio para a formação de hidrōxido de alumí nio, trivalente positivo, que se associa às impure zas da āgua, de carga negativa, formando os flocos que irão sedimentar no fundo da piscina ou na areia do flitro. Sabe-se que para $1 \mathrm{mg} / 1$ de sulfato de alu minio é necessärio $0,4 \mathrm{mg} / 1$ de alcalinidade natural ou adicionada em $\mathrm{CaCO}_{3}$, sendo que a melhor faixa de pH para a floculação das águas de piscinas com o suI fato de aluminio está entre 6,0 e 8,0 (CETESB, 1983) 24 . 
Outra importância do $\mathrm{pH}$ estā relacionada à desinfecção das āguas. Em pH baixo $(<7,5)$ o cloro livre, sob a forma de ācido hipocloroso (HOCl), tem maior poder bactericida do que o ácido hipocloroso dissociado, que aparece nos valores de $\mathrm{pH}$ mais altos (MANFRINI, 1974) ${ }^{61}$.

0 pH ōtimo para àgua de piscinas estā entre 6,7 e 7,9 pois o pH dos 01 hos è de 7,2 e āguas manti das nesta faixa de tolerância não prejudicamos olhos dos banhistas. DECRETO No $13.166^{29}$, de 20 de jane ro de 1979 que aprova a Norma Técnica Especial (NTE) relativa à piscina, do Estado de São Paulo.

pH muito alto pode causar a precipitação de minerais dissolvidos na água, como cālcio ou ferro, causando cor e turbidez e favorecendo incrustações nos filtros e encanamentos. pH baixo $(<7,0)$ causa corrosão de metais dos sistemas de recirculação (AN DRADE E MOREIRA, 1975$)^{3}$.

Em relação ao pH das piscinas estudadas, (Grā fico Nọ 01 , item 4.1 .1$)$ foi observado que:

- a piscina A apresentou pH 6,6 nos meses de outubro e junho, estando abaixo do limite 6,7 o que pode ter contribuido para uma leve irritação dos olhos dos banhistas. Nessa piscina o pH 6,9, emabril, parece ter influenciado a ação do cloro $(0,4 \mathrm{mg} / 1)$, - que estā baseado em resultados bacteriológicos ne gativos da amostra (Quadro NQ 05, anexo I).

- a piscina B, nas quatro coletas realizadas, apresentou pH entre 6,8 e 7,8 , portanto, dentro da faixa permitida. A àgua utilizada na piscina $\bar{e}$ a 
distribuida pela estação de tratamento de āgua da cí dade, o que deve ter contribuido para manter esse parâmetro dentro dos limites de tolerāncia;

- a piscina $C$, em todas as coletas realiza das, apresentou pH de acordo com os limites de 6,7 a 7,9 , embora a āgua utilizada seja de fonte;

- a piscina $D$, nos meses de agosto e fevere ro, apresentou pH acima de 8,2 o que, em geral, pró voca irritação dos olhos e ressecamento da pele dos banhistas. A āgua que alimenta essa piscina è ori ginäria de fonte. Foi observado, em coleta do manan cial, que $0 \mathrm{pH}$ da āgua estava em torno de 7,8 , pare cendo, portanto, que essa alcalinidade não the era própria, podendo estar relacionada ao tratamento;

- as piscinas $E$ e $F$, nas quatro coletas, presentaram o pH de acordo com a faixa de tolerāncia;

- a piscina G em uma coleta estava com pH igual a 8,0 (junho), e em trēs igual ou superior a 8,2 , o que vem confirmar a reclamação dos usuários em relação ao ressecamento da pele e irritação dos olhos. Este fato pode estar relacionado à quantida de e ao tipo de cloro usado, cloro cal "QC", que al tera o pH da āgua para mais alcalino. Essa piscina é abastecida por āgua de poço profundo, que poderia apresentar teor alcalino elevado. Foi observado, en tretanto, em coleta do manancial, que o pH estava em torno de 7,3 , não parecendo, tal como verificado na 
piscina $D$, ser a alcalinidade relacionada à āgua de alimentação e sim ao tratamento.

\section{1 .4 Cloro}

No Brasil, em geral, o cloro e seus compos tos são os mais utilizados na desinfecção de āguas de piscinas.

Segundo AZEVEDO NETTO $(1974)^{5}$, ao se exami nar o efeito bactericida da cloração, é essencial co nhecer os compostos produzidos na ägua, os quais de pendem da natureza das impurezas presentes e do $\mathrm{pH}$ da àgua.

Desse modo, dois casos extremos podem ser considerados: (I) reações do cloro com a āgua, com a formação do cloro residual livre (CRL) e (II) reações do cloro com a amónia, formando o cloro residual com binado (CRC).

(I) - O cloro, dissolvido na àgua pura ou su ficientemente pura, reage para formar o ācido hipo cloroso $\left(\mathrm{HOCl}_{1}\right)$ :

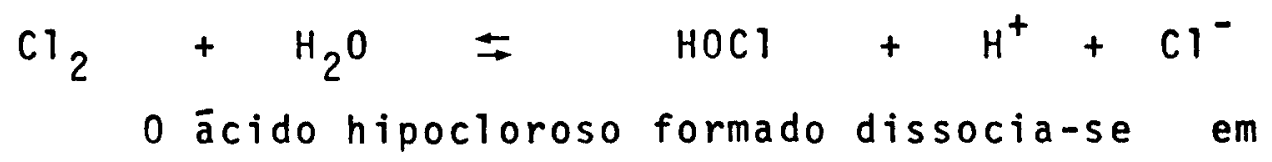
maior \% em cātions de hidrogēnio $\left(H^{+}\right)$e ānions hipo clorito $\left(\mathrm{OCl}^{-}\right)$, em função da faixa de $\mathrm{pH}(>7,6)$ :

$$
\mathrm{HOCl} \quad=\quad \mathrm{OCl}^{-}+\mathrm{H}^{+}
$$

o cloro existente na àgua na forma de ācido hipocloroso e de ion hipoclorito é definido como clo 
ro residual livre (ROSSIN, 1979) 84.

Tanto ācido hipocloroso como o Ton hipoclori to têm ação desinfetante, mas o ācido hipocloroso é muito mais eficiente.

(II) - Quando o cloro è aplicado àsāguas com presença de matēria orgānica, amōnia e/ou compostos amoniacais, forma compostos clorados ativos, denomi nados cloraminas. 0 cloro, sob a forma de ácido hi pocloroso, combinando-se com a amōnia presente na āgua, forma: monocloramina $\left(\mathrm{NH}_{2} \mathrm{Cl}\right)$, dicloramina $\left(\mathrm{NHCl}_{2}\right)$ e tricloreto de nitrogénio $\left(\mathrm{NCl}_{3}\right)$, de acordo com as seguintes reações:

$$
\begin{aligned}
& \mathrm{NH}_{4}^{+}+\mathrm{HOCl}=\mathrm{NH}_{2} \mathrm{Cl}+\mathrm{H}_{2} \mathrm{O}+\mathrm{H}^{+} \\
& \mathrm{NH}_{2} \mathrm{Cl}+\mathrm{HOCl} \\
& \mathrm{NHCl}_{2}+\mathrm{HOCl} \rightleftharpoons \mathrm{NCl}_{3}+\mathrm{H}_{2} \mathrm{O}+\mathrm{H}_{2} \mathrm{O}
\end{aligned}
$$

A dicloramina $\left(\mathrm{NHCl}_{2}\right)$ é de maior efeito bac tericida.

Conforme jā foi exposto, o cloro reage nas āguas formando compostos, conforme esquema abaixo: (ROSSIN, $1979^{\circ 4}$ - modificado)

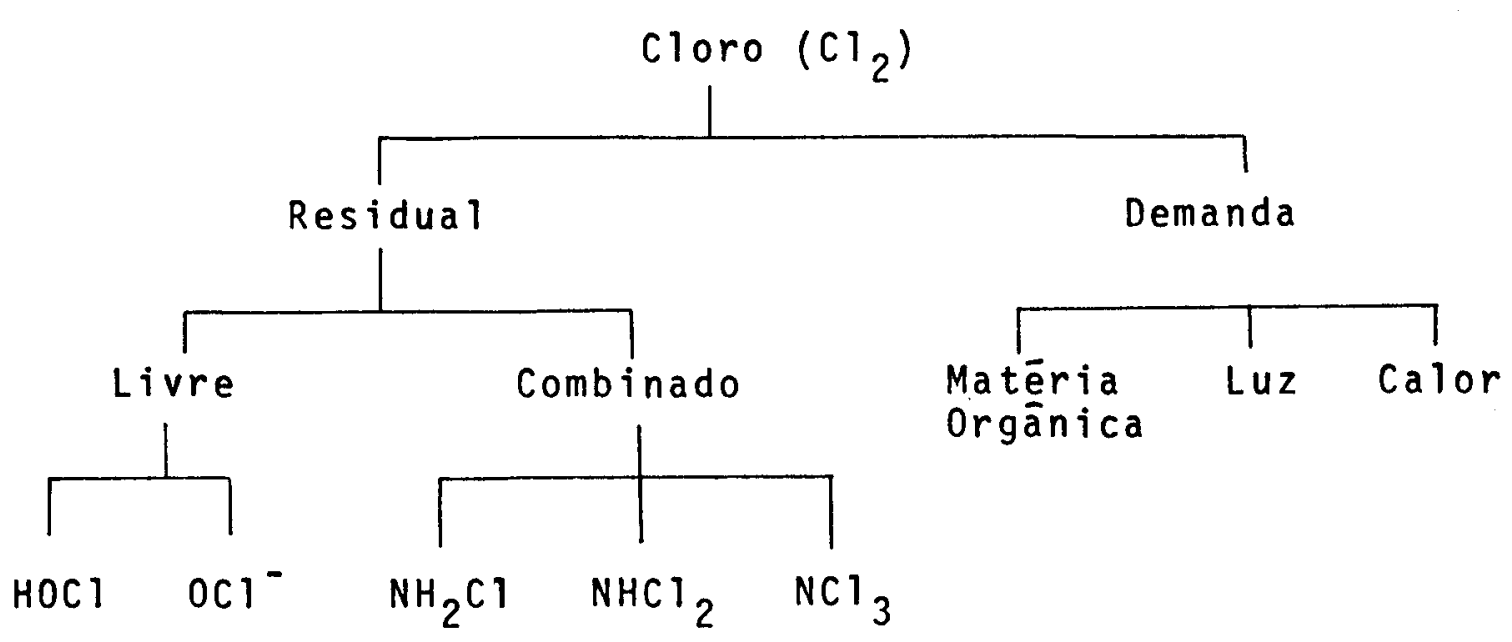


Esses compostos apresentam poderes de desin fecção muito diferentes, por isso, não basta medir o residual obtido, é necessārio determinar sua forma. Da anālise do Quadro No 04, anexo I, pode-se notar que o $\mathrm{pH}$ è um fator muito importante no processo da cloração das àguas, e que maior eficiência da desin fecção (100\%) ocorre em pH igual ou menor que 5,0 (AZEVEDO NETTO, 1974$)^{5}$.

"As percentagens de residuais diferentes que se formam dependem essencialmente dos seguintes fato res: reação cloro/Nitrogênio, $\mathrm{pH}$ e temperatura" (ROS SIN, 1979) 84 .

A demanda do cloro em āguas de piscinas pode estar relacionada ao produto usado; a presença de ma téria orgānica, elou amōnia introduzida pelo suor el ou urina dos frequentadores; ao nümero de banhistas incompatível com a ārea mínima desejāvel por usuārio, que segundo AZEVEDO NETTO $(1975)^{6}$, é de 2 a $4 \mathrm{~m}^{2} /$ pes soa.

Com foi descrito anteriormente, os compostos de maior interesse na desinfecção das āguas são: o àcido hipocloroso, na forma de cloro residual livre e a dicloramina, na forma de residual combinado.

Segundo $\operatorname{MOOD}(1950)^{65}$, o cloro residual 1 i vre é um bactericida mais efetivo do que o cloro re sidual combinado em tratamento de äguas de piscinas.

Alguns autores observaram que a morte das bactérias não se dá tão rapidamente pela ação do clo ro, portanto, frequentemente são isoladas de àguas contendo $<0,3 \mathrm{mg} / 1$ de cloro residual total (HOADLEY e KNIGHT, 1975)55. 
Conforme citação de AHO e HIRN (1981) ${ }^{1}$, Ja cobson relatou a presença de Pseudomonas aeroginosa em āguas de piscinas contendo nivel de cloro livre aceitāvel, supondo-se que o minimo seja de $0,4 \mathrm{mg} / 1$. De acordo com O DECRETO No $13.166^{29}$, de 23 de janeiro de 1979, que aprova a Norma Técnica Espe cial (NTE), relativa as piscinas do Estado de São Pau 10, a concentração de cloro residual preconizada pa ra àguas de piscinas estā entre 0,5 e $0,8 \mathrm{mg} / 1$.

Quanto à escolha do produto químico aser usa do na desinfecção, deve-se considerar, além dos fato res jā comentados, a concentração e tempo de contato. Do ponto de vista económico, deve-se levar em conta esses aspectos, pois dependendo do volume de água a ser tratada, muitas vezes, um produto unitariamente mais barato, mas com concentração de cloro ativo bai $x a$, pode tornar-se mais oneroso.

Pela anālise do Grä́fico NQ 01 do îtem 4.1.1 e da Tabela Nọ 01, anexo II, pode ser observado que no desenvolvimento desta pesquisa foi verificado que as piscinas $B, D, E, F$ e $G$ não apresentaram residual de cloro em nenhuma das coletas;

A piscina A apresentou, em janeiro, $0,1 \mathrm{mg} / 1$ de cloro residual livre. Esta concentração pode ser desprezada com relação ao efeito desinfetante, tendo em vista que o minnimo desejāvel è de $0,5 \mathrm{mg} / 1$. Em abril, a concentração encontrada foi de $0,4 \mathrm{mg} / 1$ que, mesmo estando fora do limite minimo estabelecido, pa rece ter concorrido para melhorar as condições de pó tabilidade da àgua, conforme anālises bacteriolōgi cas da amostra. Nas duas outras amostras coletadas, 
não foi detectado residual de cloro;

A piscina $C$, no mēs de fevereiro, apresentou concentração de cloro $0,2 \mathrm{mg} / 1$, abaixo do minimo es tabelecido, mas com resultados bacteriológicos de acordo com os padrões de potabilidade. Nas outras três amostras obtidas, não havia cloro residual.

os fatores que contribuiram para a ausência de cloro residual na àgua das piscinas podem ter si do: a falta de pessoal devidamente capacitado para operar esses sistemas, sem conhecimento da dosagem dos produtos químicos a serem usados; a falta de equipa mentos adequados (na maioria das vezes ausentes) co mo aparelhos para medir a concentração de cloro.

\section{1 .5 Cor}

E um parâmetro estētico, tem pouco significa do sanitário, a não ser algumas vezes para indicar a origem da àgua. No tratamento da āgua pode compli car a coagulação. Os padrões de acordo com o DECRE TO No $12.486^{28}$ de 20 de outubro de 1978, limitam a intensidade da cor, numa àgua aceitável, a 20 e, pré ferivelmente, a menos de $10 \mathrm{mg} / 1(\mathrm{Pt} / \mathrm{l}-\mathrm{Hazen})$.

A cor na āgua, geralmente, se deve à presen ça de matēria de origem orgānica ou mineral, em solu ção (BABBIT e col., 1962) ${ }^{7}$.

Na Tabela Nọ 01, do anexo I, pode ser obser vado que, nas amostras de āgua coletadas para a rea lização desta pesquisa, o valor māximo de cor encon trado foi de $10 \mathrm{mg} / 1$ - $\mathrm{Pt} / 1$, portanto, dentro do $1 \underline{i}$ mite minimo estabelecido. 


\subsubsection{Alcalinade}

"A alcalinadade das āguas naturais é devida, principalmente, à presença de carbonatos, bicarbona tos e hidrōxidos. Os compostos mais comuns são os seguintes: Hidrōxidos de Cálcio ou de Magnésio, Car bonatos de Cālcio ou de Magnésio, Bicarbonatos de Cál cio ou de Magnésio, Bicarbonatos de Sōdio ou de Po tássio". Dependendo do $\mathrm{pH}$ das àguas, os compostos que podem ser encontrados são os seguintes: Hidrōxi dos e Carbonatos, pH acima de 9,4; Carbonatos e Bicar bonatos, $\mathrm{pH}$ entre 8,3 e 9,4; apenas Bicarbonatos, $\mathrm{pH}$ entre 4,4 e 8,3 (AZEVEDO NETTO, 1979) ${ }^{4}$.

Na natureza, a àgua nunca é encontrada em es tado de absoluta pureza, devido às substâncias que nela se dissolvem (AZEVEDO NETTO, 1979)".

"As āguas naturais, normalmente, têm uma rea ção alcalina, porēm a acidez não $\bar{e}$ necessariamente indesejāvel. Não são colocadas limitaçōes padrões de acidez ou alcalinidade sobre a àgua potável" (BAB BIT e col., 1962) ${ }^{7}$.

A alcalinidade é importante no processo de corrosão dos sistemas de distribuição e tambēm pode produzir sabor na āgua. E uma medida de capacidade "tampão" da āgua que, segundo os critērios fisicoquímicos para caracterização de āguas para consumo humano deve ter como limites máximos recomendados, em mg/l $\mathrm{CaCO}_{3}$ : Hidrōxido= zero; Carbonato $=120 ; \mathrm{Bi}$ carbonato $=250 \quad(\text { CETESB, 1983) })^{3}$.

Através desta pesquisa foi verificado (Tabe la Nọ 01, anexo II) que os resultados de alcalinida 
de das āguas das piscinas estudadas estavam dentro dos limites estabelecidos pelos critérios físico-qui micos para caracterização de àguas de consumo humano.

\section{1 .7 Cloretos}

Altas concentrações de cloretos na āgua pro vocam sabor desagradāvel e aumento do potencial cor rosivo. Um excesso de cloretos $\bar{e}$ usualmente uma in dicação de poluição (BABBIT e col., 19627 , CETESB, $1983)^{23}$.

0 limite recomendado de cloretos (mg/l $\mathrm{Cl}$ ), de acordo com O DECRETO No $12.486^{28}$, de 20 de outu bro de 1978, para àgua de abastecimento pūblico é de $250 \mathrm{mg} / 1 \mathrm{Cl}$.

Foi verificado neste trabalho que nas pisci nas pesquisadas as concentraçōes de cloretos estavam sempre abaixo de $250 \mathrm{mg} / 1 \mathrm{Cl}$.

\subsection{Indicadores Biológicos}

\subsubsection{Bactērias}

Todas as bactērias pesquisadas neste traba Tho com a finalidade de verificar as condições sani tārias das āguas de piscinas, em geral, são indicado ras de poluição fecal.

\subsubsection{Determinaçāo de coliformes}

o grupo coliforme mereceu consideração como 
indicador de poluição, porque estas bactērias estão sempre presentes em grande nümero na flora intesti nal humana e de animais de sangue quente (GELDREICH, $1967^{44}$; NORMALIZAÇAO L 5202, 1978$)^{68}$.

A presença de coliformes totais na àgua indi ca poluição com risco potencial da presença de orga nismos patogénicos e a sua ausēncia é evidēncia de uma āgua bacteriologicamente segura (MALLMANN, 192860; GELDREICH, $1967^{44}$; NORMALIZAÇAOO L 5202, 1978) ${ }^{6}$. En tretanto, värios autores concordam com a declaração feita em 1963 pelo Comitê de Atividades de Saūde Pū blica da Sociedade Americana de Engenharia Civil:

"existe pouca ou nenhuma prova de que o perigo de doenças está diretamente associado ao grande número de coliformes" (FOSTER e col., 197140; DUTKA, 1973) 33 .

Algumas bactērias do grupo coliforme têm ca pacidade de se multiplicar na āgua e são encontradas no solo e em vegetais, mais foi constatado que entre os coliformes existem bactērias comprovadamente de origem fecal que não se multiplicam com facilidade no meio externo e têm sobrevivéncia semelhante às da patogēnicas. Portanto, a ocorrēncia de poluição fé cal na āgua pode ser detectada e medida pelo teste de "coliformes fecais" que está baseado na fermenta ção da lactose a $45,5^{\circ} \mathrm{C}$. (GELDREICH, 197042; NORMA LIZAÇÃO L 5202,1978$)^{68}$.

0 interesse pelos coliformes fecais (Esche richia coli) data de 1885 quando o Professor Theodor Escherich propós usar Bacizzus coli, do qual o nome "collforme" foi derivado, como indicador de poluição. (DUTKA, 1973 33 ; GELDREICH, 1975) ${ }^{43}$. 
Segundo GELDREICH $(1970)^{42}$, investigações da significāncia dos coliformes no meio ambiente tēm de monstrado que estes organismos indicadores de polui ção têm correlação positiva com animais de sangue quente e contaminação fecal.

Por estarem relacionados à poluiçāo, os colị formes fecais são considerados um dos mais importan tes indicadores de risco potencial para a saūde pú blica (DUTKA, 1973) $)^{3}$.

VICTORIN $(1974)^{94}$ ressalta que o uso de coli forme não fecal como organismo indicador em āgua de piscinas é discutivel.

o critério racional de utilização de colifor mes como indicadores para āgua potāvel tornou-se du vidoso quando foi empregado para águas recreacionais (DUTKA, 1973) 33 $^{3}$. Geralmente é aceito que o uso de indices bacteriológicos das āguas recreacionais de vam ser baseados na detecção de contaminação fecal. Entretanto, tem se verificado que a maioria das in fecções adquiridas, atravēs de contato com àgua espe cialmente em piscinas, são as do trato respiratório superior e pele (FOSTER e col., 197140, DUTKA, 1973) 33. Conforme Gilcreas, relatado por ROBINTON e c01., (1957) 82 , bactērias do grupo coliforme são ina dequadas como indice de poluição de águas de piscinas, porque o maior significado da poluição bacteriana em tais āguas não è de origem intestinal. Portanto, pa ra esse tipo de risco dificilmente os coliformes po dem ser empregados (DUTKA, 1973) 33 $^{3}$

Vários outros pesquisadores comentam que os coliformes fecais podem não ser o melhor indicador 
do nümero de organismos advindos do corpo humano du rante a natação (VICTORIN, 1974) ${ }^{94}$. Assim, como não hă conhecimento de organismos específicos para detec tar esses riscos em potencial para a saūde, uma solu ção ōbvia é usar dois ou mais organismos indicadores (DUTKA, 1973) $)^{33}$.

A determinação de coliformes fecais é aplica da na investigação da qualidade sanitāria de āguas de recreação, embora esse procedimento não seja recomen dado como substituto dos testes de coliformes totais como prova de potabilidade. Tal observação decorre do fato de não ser admitido, de acordo com a legisla ção vigente, nenhum tipo de bactērias do grupo coli forme em àgua tratada. (NORMALIZAÇÃO L 5202, 1978) ${ }^{68}$; AMERICAN PUBLIC HEALT ASSOCIATION, 1980) $)^{2}$.

0 indice de organismos coliformes permitido em piscinas, conforme MALLMANN $(1962)^{59}$, é o mesmo que para àgua potāvel.

Na falta de legislação específica a respeito do controle da balneabilidade das piscinas para o Es tado de Mato Grosso do Sul, adotamos as mesmas exi gências relativas a padrões de qualidade da āgua pa ra abastecimento püblico.

Coliformes totais foram isolados nas pisci nas A (outubro, janeiro, junho); B (outubro, janeiro, abril); C (novembro); $F$ (dezembro, março, junho, se tembro). Este fato pode ser verificado no Grāfico No 02 a seguir, o qual foi baseado no Quadro NQ 05 , do anexo I. Foi observado que na piscina $F$ esses or ganismos foram detectados em todas as coletas e apa receram, frequentemente, em maior nümero em relação 


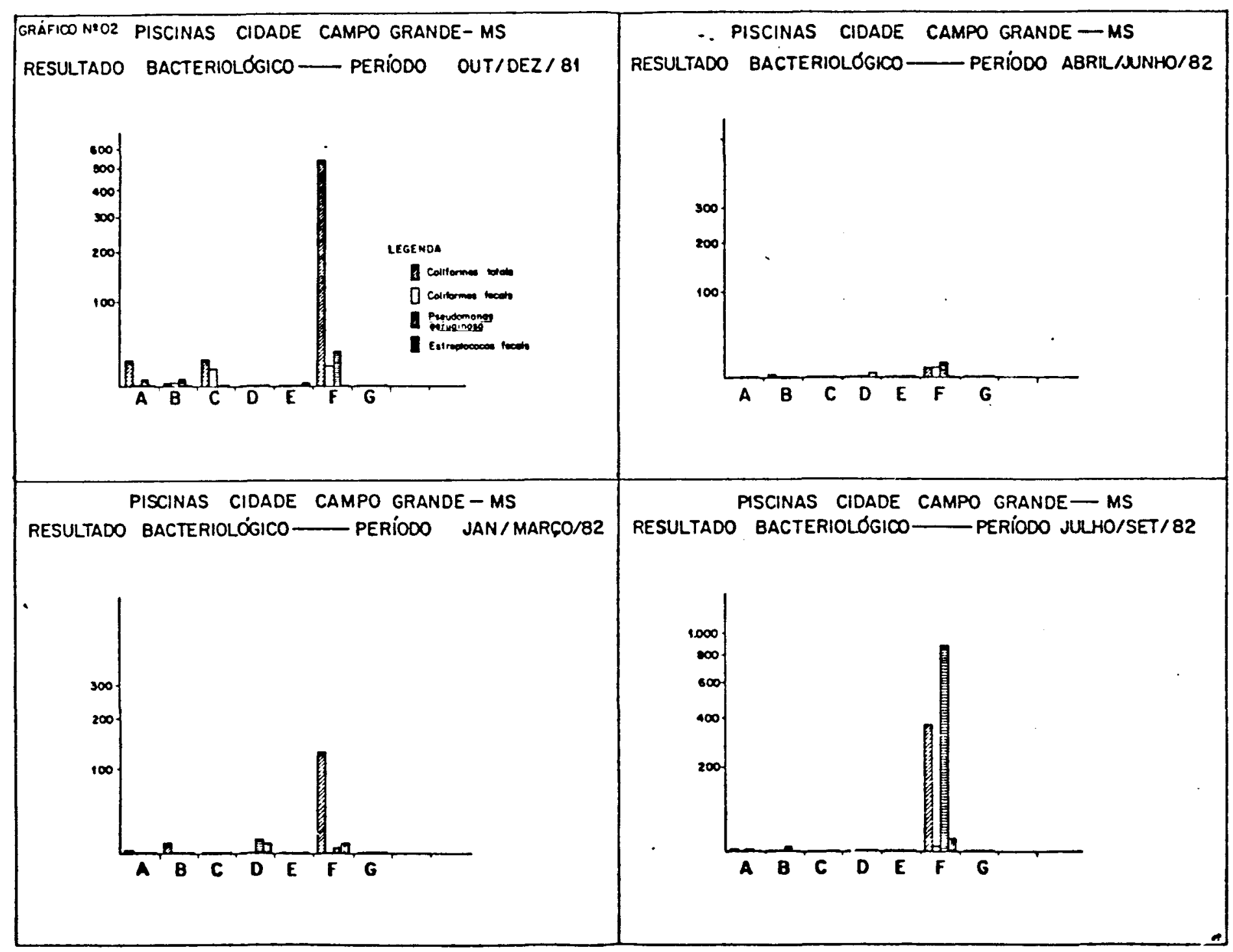


às outras. 0 aumento considerável de organismos do grupo coliforme nessa piscina, no més de dezembro, po de estar relacionado a penetração de água de enxurrá da no tanque. Considerando as quatro coletas do pe ríodo amostrado, foi nessa piscina que o indice de coliformes totais (NMP/100 ml) apresentou resultade discrepante em relação às demais (piscina $A=27 ; B=$ $13 ; C=22 ; D<2 ; E<2 ; F=1.028 ; G<2)$, Tabela No 02 , do anexo II.

Da anālise do Gräfico Nọ 02 referido no pară grafo anterior, os coliformes fecais foram encontra dos nas piscinas B (outubro); C (novembro); F (dezem bro, junho e setembro). Foi demonstrada ainda sua presença em $75 \%$ das amostras da piscina $F$ e, durante - periodo estudado, a densidade dessas bactérias ex pressa em NMP/100 ml foi a mais elevada. (Tabela No 02, anexo (I).

Em 07 de dezembro de 1976, a Portaria No 536, do MINISTERI064 do Estado do Interior do Brasil, es tabeleceu uma classificação no tocante à qualidade das āguas interiores ou marinhas destinadas à recrea ção de contato primārio, sem que tenham sido ressal tadas as exigèncias para àguas de piscinas.

Para avaliar as condiçōes de potabilidade das àguas das piscinas estudadas, tentou-se uma classifi cação baseada na determinação do NMP/100 ml de bactê rias do grupo coliforme, de acordo com a Tabela No 03 , anexo II. As piscinas $D, E$ e $G$, qua apresentaram indice menor do que 2 no periodo estudado, foram de nominadas de "prōprias para o uso", enquanto que as piscinas $A, B, C, F$, com nūmero de organismos igual 
ou maior do que 2, foram chamadas de "imprōprias para o uso".

Durante a pesquisa, nas piscinas $B, C$ e $F$, foi observada a presença de coliformes fecais. Basea do nas afirmaçōes de DUKTA $(1973)^{33}$, estas piscinas apresentaram risco potencial à saūde pūblica.

\subsubsection{Determinação de Estreptococos fecais}

KENNER (1978) afirma que em 1900 Hostoun jā havia observado a presença de estreptococos fecais em amostras de àgua poluida, mas o reconhecimento desses microrganismos como indicadroes de poluição fecal da ta de 1910 (NORMALIZAÇAO L 5205, 1978) ${ }^{69}$. Foi em 1955 que a sua utilização se fez efetiva com a intró dução de meios de cultura contendo azida s̄odica (SLA NETZ E BARTLEY, $1964^{\circ}{ }^{\circ}$; NORMALIZAÇAO L 5205, 1978)69.

0 uso de estreptococos fecais como indicado res de poluição estā associado às seguintes razões: não correm em āgua limpa e solos de àreas virgens;ge ralmente nāo se multiplicam em āguas poluidas e en contram-se em número inferior a Escherichia coli; em geral sua resistēncia aos poluentes químicos em de terminadas āguas é maior do que a dos coliformes; ocor rem em número relativamente alto em excretas humanos e de animais de sangue quente; em fezes da maioria dos animais de sangue quente sua predominância é maior em relação aos coliformes fecais (CABO RAMON, $1972^{19}$; KENNER, $1978^{56}$; NORMALIZAÇAOO L $5205,1978^{69}$; CLAUSEN e col., $1977^{22} ;$ GELDREICH, 1970)42,47. 
Estreptococos fecais em āguas de piscinas são mais resistentes ao cloro do que as bactérias do gru po coliforme (MOOD, 1950)65. Assim, não é surpresa que alguns investigadores argumentem que os Estrepto cocos são mais seguros indicadores de poluição fecal do que os coliformes (KENNER, 1978) 56 .

Segundo SLANETZ e BARTLEY (1964) ${ }^{\circ}$, existem muitas provas para sugerir que estreptococos fecais são mais práticos e seguros indicadores de poluição fecal da água do que os coliformes.

Uma das vantagens do estreptococo fecal co mo indice de poluição fecal está baseada no reconhe cimento de que estes organismos normalmente são en contrados no trato intestinal dos homens e dos an mais (SLANETZ e BARTLEY, 1964) 88. $^{8}$.

Existem dois biotipos de limitada significa ção sanitária dentre o grupo dos estreptococos: S.fae calis var. liquefaciens e $S$. faecalis com a capacida de de hidrolizar o amido. Esses dois biotipos não são restritos ao intestino do homem e de animais de sangue quente, podendo ocorrer associados à vegeta ção e certos tipos de solos. Esse fato limita sua utilização como indicador de poluição fecal, embora seja de grande valor nos estudos correlacionados aos coliformes fecais onde pesquisas realizadas demons tram que quando a relação $\frac{C F}{E F}$ for superior a 4,0 a poluição è de origem humana e se for inferior a 0,7 , de origem animal. Entretanto, esta correlação tem aplicação restrita e pode ser utilizada apenas em pontos de lançamento de despejo, pois durante o per curso vārios fatores podem alterar a inter-relação 
entre esses sistemas indicadores (GELDREICH, 196744; GELDREICH e KENNER, 196948; CLAUSEN e C01., 197722; NORMALIZAÇAO L 5205,1978$)^{69}$.

A presença de estreptococos em àguas de pis cinas indica uma condição insegura, porque, na maio ria das vezes, è encontrado em amostras de àgua com características de poluição fecal, is to é, com E. coli (MALLMANN, 1928)60.

FOSTER e col. (1971) 40 relatam que Mallmann tem constantemente defendido o uso de estreptococos como indicador de poluição.

Geralmente a ocorréncia de estreptococos fe cais na água indica poluição fecal e a ausência suge re pouca ou nenhuma poluição por animal de sangue quente (GELDREICH, 1970) 47 .

BLACK e col., $(1970)^{11}$, em seus estudos so bre a desinfecção de āguas de piscinas, observaram que, embora os estreptococos fecais sejam mais resis tentes ao cloro do que os coliformes, foram encontra dos com menor frequência.

o estreptococo fecal è indicador não muito sensĩvel de poluição recente, entretanto, sua presen ça em amostra de àgua, na ausēncia de Escherichia co $2 i$, se converte em indicador extraordinariamente útil (CABO RAMON, 1972)19.

Os resultados do presente trabalho conforme Gráfico Nọ 02 , do îtem 4.2.1.1, mostram o isolamento de estreptococos fecais das piscinas $D$ (fevereiro, maio); E (novembro) e F (março; setembro). Durante o periodo estudado, foi na piscina $F$ que essas bacté rias apareceram em maior nümero (Tabela No 02, anexo II). 
Foi observado que durante o periodo de estu do os organismos do grupo coliforme foram encontra dos mais vezes do que estreptococos fecais (Tabela No 02 , anexo II). Tendo em vista que estreptococos fecais geralmente não se encontram em āgua limpa, es te resultado coincide com o esperado.

Foi interessante notar que nas piscinas D (fe vereiro, maio), E (novembro) e $F$ (março) estreptoco cos fecais estavam presentes na ausência de Eschere ria coli, o que pode sugerir uma poluição fecal de origem recente (Quadro No 05, anexo I).

Na piscina $F$, no més de setembro (Quadro No 05), observou-se a presença de $E$. coli e de estrep tococos fecais, o que pode indicar com maior seguran ça poluição de origem fecal e condições insatisfatō rias para o uso.

\subsubsection{Determinação de Pseudomonas aeruginosa}

0 interesse pelo estudo da Pseudomonas aer $\underline{u}$ ginosa estā relacionado à sua importāncia como pató geno para o homem e os animais, determinada por sua versatilidade bioquímica e resisténcia a agentes an ti-bacterianos e ao fato de ser elemento formador de limo (HOADLEY, 1968) 54 .

Foi observado que $P$. aeruginosa $\bar{e}$ mais resis tente à cloração do que os coliformes (DUTKA, 1973) ${ }^{3} 3$. Segundo HOADLEY $(1968)^{54}$, o trato intestinal do homem parece representar o maior reservatōrio de P. aeruginosa, atingindo o meio ambiente e em parti cular āguas de superfície. 
Animais domésticos, principalmente ruminan tes jovens, podem atuar como fonte secundāria de $P$. aeruginosa em àgua de superfície. Entretanto, pa rece que $P$. aeruginosa não pode ser considerada co mo um habitante normal do trato intestinal de animais domésticos (HOADLEY, 1968) 54 .

Conforme Hoadley e col., citados por DUTKA $(1973)^{33}$, Pseudomonas aeruginosa provavelmente não ocorre em águas não afetadas por atividades do homem e de animais domésticos.

Mediante declarações de Taylor, em HOADLEY $(1968)^{54}$, Pseudomonas aeruginosa não ocorre em águas limpas e, quando encontrada, esta geralmente acompa nhada por outros organismos fecais, como por exemplo Escherichia coli.

HOADLEY $(1968)^{54}$ relata que diversos autores têm aprovado a sugestão de Geer's de que a presença de $P$. aeruginosa em āgua potāvel nāo deveria ser ig norada.

Pseudomonas aerusinosa tem sido indicada pa ra ser incluída nos testes de rotina de āguas potá veis, considerando o perigo potencial representado por essa bactéria e não pelo valor como indicador de poluição fecal (HOADLEY, 1968) ${ }^{54}$.

Vārios estudos tém demonstrado que $P$. aerug $\underline{i}$ nosa pode ser isoladas de āguas de piscinas (HOADLEY e KNIGHT, 1975)55.

Segundo Botzenhart e col., citados por EX NER e HAVENITH $(1981)^{35}$, P. aeruginosa e outras Pseudomonas se multiplicam principalmente no filtro e, quando de sua lavagem, podem ser levadas para a 
āgua. Esses microrganismos parecem ter valor como indicadores da qualidade da àgua de piscinas (FOSTER, $1971)^{40}$

Segundo Hoadley (1968), P. aeruginosa deve ria ser considerada como indicador adicional de po luição (HOADLEY, 1968) 54 .

0 papel de $P$. aeruginosa como indicador da qualidade da àgua estā sendo cogitado, especialmente como indicador potencial de infecção do trato respi ratōrio superior (DUTKA, 1973) 3 $^{3}$. Portanto, P. aeru ginosa representa provāvel indicador de balneabilida de baseado em forte relação entre qualidade da āgua e saūde dos banhistas (HOADLEY, $1968^{54}$; CABELLI e Co1., 197619; SEYFRIED e FRASER, 1980$)^{85}$.

Muitos autores têm sugerido que hà correla ção entre ocorrência de $P$. aeruginosa em āguas de pís cinas e otite externa dos nadadores (HOADLEY, 196854; HOADLEY e KNIGHT, $1975^{55}$; DUKTA e SHERRY, $1978^{34}$; SEY FRIED e FRASER, 1978) 86 . HOADLEY e KNIGHT $(1975)^{55}$ ob servaram que $P$. aeruginosa foi mais frequentemente 1 solada de ouvido externo infectado de nadadores do que entre não nadadores; e tambëm que em nadadores essas infecções tendem a ser mais severas. Entretan to, parece que o ato de nadar tem importância primá ria no desenvolvimento de otite externa e o isolamen to de Pseudomonas aeruginosa de āgua recreacional constitue um perigo para a saūde pública (SEYFRIED e FRASER, $\left.1978^{86}, 1980\right)^{85}$.

Pelo grāfico Nọ 02, ĩtem 4.2.1.1 e Quadro Nọ 05, anexo I, pode-se verificar que Pseudomonas aer $\underline{u}$ ginosas foi encontrada nas piscinas A e B (outubro, 
junho); $D$ (fevereiro) e $F$ (dezembro, março, junho, se tembro). No més de setembro, na piscina $F$, o nūmero de $P$. aeruginosa encontrado chamou atenção pela dife rença em relação ao seu nümero nas outras piscinas. Esse tipo de bactéria foi observado em todas as amos tras coletadas nessa piscina, o que pode ser verifi cado no Quadro No 05, anexo I. Durante o periodo da pesquisa, foi na piscina $F$ que esses microrganismo apareceram em maior número, como evidenciado na Tabe la No 02, anexo II. E interessante notar que na pis cina $C$, revestida de resina sintética (Quadro Nọ 01 , anexo I), não foi detectada a presença de $P$. aerugi nosa (Quadro Nọ 05, anexo I) e nem de limo nas pare redes (Quadro No 08, anexo I).

Pseudomonas aeruginosa, em geral, foi encon trada acompanhada de outros microrganismos de origem fecal, bactērias do grupo coliforme e estreptococos fecais, o que vem de encontro às declarações de Tay lor (Quadro No 05, anexo I). Considerando que a pre sença de $E$. coli e estreptococos fecais indicam po luição fecal e que na maioria das vezes quando foi encontrada $P$. aeruginosa um desses ou esses organis mos estavam presentes, provavelmente essas cepas de P. aeruginosa tenham origem fecal.

Pode ser aqui ressaltado que durante a execu ção deste trabalho, as piscinas $A, B, D$ e $F$ apresen taram risco de saūde aos usuärios no que se refere a presença de $P$. aeruginosa e a relação com otite exter na.

\subsubsection{Contagem padrão de colōnias de bactērias}


Para se estimar a população de bactérias he terotrōficas aerōbias e anaeróbias facultativas pre sentes na àgua, com diferentes graus de desenvolvi mento nas condições de nutrição, temperatura e tempo de incubação definidos para o teste, è utilizada a contagem padrão em placas ( NORMALIZAÇAO L 5201 , $1978)^{67}$.

A āgua contém bactérias, cujas necessidades nutritivas e de temperatura ōtima para o desenvolvi mento são variáveis, portanto, é impossível se obter uma contagem "total" de bactērias (NORMALIZAÇAOO L $5201,1978)^{67}$.

Em suprimento de āgua potável, a flora micro biana ē altamente variāvel em nūmero e espécie. os organismos predominantes presentes na àgua potāvel pertencem aos gēneros: Pseudomonas, Flavobacterium, Achromobacter, Proteus, Klebsiella, Bacizlus, Spiriz Zum, Corynebacterium, Aerobacter, etc. (GELDREICH, $1973^{45}$; NORMALIZAÇAOO L 5201,1978$)^{67}$.

"A influência inibidora de alguns organismos, presentes em altas densidades na flora bacteriana da àgua, é um fator importante, uma vez que podem impe dir a deteç̧ão de coliformes, seja devido à produção de fatores de inibição, seja por um desenvolvimento mais intenso destes organismos, sobrepujando uma me nor população de coliformes. Estudos realizados re velaram que quando o nūmero de colōnias aumenta até um nĩvel de 500/m1, a frequéncia na detecção de colí formes tambēm aumenta, porém, quando a população bac teriana excede a $1000 / \mathrm{ml}$, a frequēncia na detecção de coliformes decresce" (NORMALIZAÇÃO L 5201, 1978) ${ }^{67}$. 
A quantidade de partículas contendo bactē rias envolvidas por camada protetora e não sendo al cançadas pelo cloro, provavelmente justifica a alta contagem de bactērias (VICTORIN, 1974) 94.

Densidades elevadas de microrganismos naăgua, a lēm de representarem um risco à saūde, podem ocasio nar outros problemas, como: deterioração da qualida de da àgua, sabor e odor desagradáveis, formação de limo ou pelicula, interferéncia na deteç̧ão de coli formes (NORMALIZAÇAOO L 5201, 1978) ${ }^{67}$.

Quando hā aumento sūbito do nūmero "total" de microrganismos, pode-se pensar no inicio de po luição, principalmente em āgua procedente de poços profundos e fontes (CABO RAMON, 1972)19.

Em āguas de piscinas, a determinação da den sidade de bactērias heterotrōficas aerōbias e anaerō bias facultativas é aplicada para avaliar as condi ções higiênicas, a eficiēncia das diversas etapas do tratamento e a qualidade da āgua (NORMALIZAÇAO L 5201 , $1978)^{67}$.

Na contagem padrão de colônias por $\mathrm{ml}$, as piscinas A (outubro, janeiro), B (outubro, janeiro, abril, junho), C (maio, agosto), D e E (fevereiro, a gosto) e F (dezembro, março, junho, setembro) apresen taram número de colónias superior a 300 por $\mathrm{m} 1$, sen do que nas piscinas A (outubro), B (outubro, janeiro) e $F$ (dezembro, setembro) foi impossível se fazer a contagem das colónias (Quadro Nọ 05, do anexo I).

Foi observado que nas amostras de āgua onde não foi possível realizar a contagem das colōnias es tavam presentes organismos do grupo coliforme e $P$. 
aeruginosa, sendo que $P$. aeruginosa não foi detecta da em uma das amostras. Estreptococos fecais, entre tanto, só foram observados em uma das amostras. Es tes achados, conforme pode ser evidenciado no Quadro No 05, anexo I, vèm corroborar o trabalho de DREICH, (1973) ${ }^{45}$, que não citou como exemplo nenhuma bactēria do grupo dos cocos, como componente da flo ra microbiana em āgua potāvel.

Nas piscinas, cujo suprimento de āgua era po ço profundo e fonte, foi possivel fazer a contagem das colónias em todas as amostras.

A piscina que é alimentada pela àgua do abas tecimento püblico (ETA) apresentou em todas as amos tras contagem superior a $300 / \mathrm{m} 1$. Este fato talvez possa reforçar que o tratamento da āgua dessa pisci na não estā sendo adequado.

Tambēm foi observado que nas piscinas quesão abastecidas por àgua de poço raso, a contagem de co Iōnias foi maior do que $300 / \mathrm{ml}$, a não ser na piscina A (abril) quando foi detectado um residual de cloro livre de $0,4 \mathrm{mg} / 1$. Em vista desse resultado, podese notar que a presença do cloro residual è de gran de importāncia no tratamento da āgua de piscinas.

Durante o periodo estudado foi possivel no tar que praticamente não havia nas amostras de água concentração de cloro residual e na piscina em que foi detectado um residual de $0,4 \mathrm{mg} / 1$, não houve cres cimento das bactérias pesquisadas e a contagem padrão em placas foi bastante reduzida, sendo igual a 5 co lōnias/ml (Quadro No 05, anexo I).

$\mathrm{Na}$ piscina $\mathrm{G} \circ \mathrm{pH}$ da àgua foi $\geqslant 8,2$ e os $\mathrm{mi}$ 
crorganismos não foram observados. A contagem "to tal" de bactērias foi sempre menor do que 20/ml (Qua dro No 05, anexo I); este fato parece estar relacio nado ao tipo de cloro usado no tratamento da água, cloro cal.

Em amostras de āgua da piscina $D$ (novembro), onde a turbidez estava fora do limite preconizado, não foi verificada a presença de bactērias (Quadro No 05 , anexo I).

\subsubsection{Leveduras}

Estudos realizados com āguas poluídas têm de monstrado que, do crescimento total das colónias de fungos, $50 \%$ são bolores (AMERICAN PUBLIC HEALTH ASSO CIATION, 1980) ${ }^{2}$. Essa classe de fungos tem, via de regra, desenvolvimento rápido, invadindo totalmente a superficie do meio de cultura, esgotando assim os nutrientes, e por conseguinte impedindo, por mecanis mo de competição, o crescimento pleno das leveduras presentes nas amostras semeadas.

Considerando esse fato, procurou-se utilizar metodologia que favorecesse o crescimento de leveduras em detrimento dos bolores, tais como cultivo em meios de cultura enriquecidos e uso de substāncia inibido ra de bolores - cicloheximida (RIPPON, 1982) ${ }^{\circ}$. Ape sar desse procedimento foram perdidas 64 placas de um total de 448 semeadas, em consequéncias do cresci mento excessivo de bolores, como segue: $A=8$ perdi das $/ 64$ semeadas; $B=8 / 64 ; C=12 / 64 ; D=8 / 64 ; E=12 /$ $64 ; F=8 / 64 ; G=8 / 64$. 
Das 56 amostras de āgua, foram identificados 08 géneros de leveduras e organismos semelhantes a levedura, conforme se pode observar na Tabela No 04 , do anexo II. Nessa mesma Tabela, demonstra-se que espēcies dos gêneros Candida (piescinas B, C, D, E, F, G) e Aureobasidium (B, C, D, E, F, G) foram as mais encontradas. Candida albicans pode ser identificada em trés amostras, sendo uma da piscina $D$, em novem bro (Quadro No 09, anexo I) e duas da G, em dezembro (Quadro No 12, anexo I). Foram isoladas leveduras pertencentes aos gēneros: Tricosporon (B, $F, G)$; To rulopsis (C, D, F) e Rhodotoruza (B, E). Apenas em uma das amostras se pode observar organismos dos ge neros Saccharomyces (D); Cryptococcus (C) e Pichia (F). Não houve crescimento de leveduras no material coletado da piscina A (Tabela Nọ 04, anexo II). Este fato ocorreu devido a fatores outros que não somente ao crescimento excessivo de bolores, desde que a per da de placas, por esse motivo, não foi total.

Em āguas de efluentes, encontram-se, com frę quēncia, leveduras fortemente fermentativas perten centes ao gēnero candida e tem-se proposto a sua uti lização como indicador da qualidade da āgua (DUTKA e SHERRY, 1978) ${ }^{34}$. Especialmente $C$. albicans tem sido sugerida como indicador de poluição fecal recente em ambientes aquāticos (BUCK, 197717; DUTKA e SHERRY, $1978)^{34}$. Esta espécie pode estar presente no corpo humano e de outros animais, e raramente no solo e plantas. E comumente isolada de pele, mucosas, fe zes e urina de individuos sadios (RIPPON, 1982) $0^{\circ}$. Diversos autores descreveram o isolamento de C. albi 
cans de āgua de piscina (CORDONNIER e col., 197025; KRAUS e TIEFENBRUNNER, 197557; FLOREZ e c01., 197636; EXNER e HAVENITH, 1981) ${ }^{35}$. Esta e outras espécies de Candida são introduzidas na āgua pelo prōprio banhis ta (EXNER e HAVENITH, 1981) 35 . Sabe-se que $C$. albi cans è a espécie em geral mais implicada nos casos de candidiase. Além disso, pode causar quadros clíni cos extremamente variados, desde micoses superficiais até profundas, envolvendo örgãos do sistema nervoso central e dos aparelhos respiratōrio, digestivo, cir culatōrio e urinārio (RIPPON, 1982) $)^{80}$. A capacidade de $C$. albicans produzir doença está diretamente rela cionada ao seu carāter oportunista e à suscetibilida de do hospedeiro. A quebra do equilíbrio entre leve dura em seu estado saprōfita e seu portador explica o mecanismo responsāvel pelo aparecimento de doenças na maioria dos casos. As vias direta e indireta de transmissão, porém, têm papel importante na candidía se superficial. A possibilidade de infecção a partir de àguas recreacionais não pode ser eliminada até o momento, principalmente quando existe o risco do ba nhista sofrer maceração dērmica. (DUTKA e SHERRY, $1978)^{34}$.

0 encontro de $C$. albicans nas äguas das pis cinas $D$ e G pode estar relacionado à presença de ba nhistas que podem ter introduzido essa levedura na āgua, conforme hipōtese de EXNER e HAVENITH (1981)35. Analisando os resultados bacteriológicos das pisci nas $D$ e G (Quadro Nọ 05, anexo I), quando foram iso ladas as cepas de $C$. a Zbicans, não se pode relacionar a presença dessa levedura com poluição fecal. Prova 
velmente esse fungo, em nossos achados, foi originā rio da pele e das mucosas dos usuārios.

Aureobasidium spp comumente referidas como leveduras negras, são na verdade bolores e formam co Iōnias semelhantes a leveduras "yeast-like fungi" no meio de isolamento. Este género não era de interes se médico até que VERMEIL (1971) ${ }^{93}$ publicou o prí meiro caso humano de micose superficial por Aureoba sidium puzzuzans. Espécies do gēnero Aureobasidium, patogénicas principalmente para as plantas, são comu mente encontradas em āgua do mar, tendo maior fre quencia em àgua limpa ou em ambiente aquáticos com pouca poluição. Não tem sido citado como gēnero pre dominante em estudos com esgoto (HAGLER, 1978) 52 . Na literatura consultada, não hä referéncia sobre o iso lamento de espécies deste gênero em āgua de piscina. Pela anāilise dos resultados deste trabalho, verifi cou-se que Aureobasidium sp foi isolado de àgua com irdicadores bacteriológicos de poluição fecal (pisci nas $C$ e $E$ em novembro e $F$ em dezembro, provavelmente poluĩdas) e também detectada em amostras com caracte rísticas de ägua limpa (piscinas B em janeiro; D em novembro; E em agosto, fevereiro e maio; $G$ em março) Quadro Nọ 05, anexo I. Espécies do gênero Aureobasi dium encontradas na maioria dessas piscinas, poderiam ter sido carreadas pelas chuvas das 24 horas anterio res às coletas. Os resultados destas anālises podem ser observados nos Quadros de Nọs 07 a 12, anexo I.

Espécies do gēnero Trichosporon têm sido fre quentemente isoladas de esgotos e de água doce (HA GLER, 1978) 52 . Cepas deste gēnero podem ser encon 
tradas, como saprófitas, na camada epidérmica, e es tão associadas com humanos, atacando a queratina dos cabelos e unhas. Algumas espécies têm produzido uma variedade de infecções oportunísticas, como por exem plo, endoftalmite e septicemia. Apesar de serem des critas como predominantes em àguas poluídas, pelos resultados obtidos, pode-se verificar o isolamento de Trichosporon $s p$, de água de piscina, com (B - ja neiro; F - dezembro) e sem (G - dezembro) caracterís ticas de poluição (Quadro Nọ 05, anexo I).

o gênero Toruzopsis engloba cepas patogên cas oportunistas, encontradas comumente em pele e urina de indivíduos sadios (RIPPON, 1982) ${ }^{\circ}$. Podem tambēm ser encontradas em àgua doce (poluĩda ou não) e àgua do mar (HAGLER, 1978) 52 . No decorrer deste trabalho, isolou-se Toruzopsis sp de àguas com pre sença de coliformes fecais (piscinas: C - novembro; F - dezembro). Este fato pode ser verificado no Qua dro No 05, anexo I. Na piscina D (novembro), com re sultado tambēm positivo para Toruzopsis sp, havia ba nhistas por ocasião da coleta de amostras. Desse mo do, essas leveduras provavelmente tiveram sua origem de poluição humana.

Espēcies do gênero Rhodotoruza, contaminan tes do ar, foram descritas praticamente em todos os tipos de ambientes aquāticos, inclusive àguas de pis cinas (MENDONÇA e RUFF, 1978) ${ }^{63}$. Em indivíduos sa dios podem ser encontradas na pele, urina, fezes e escarro. Têm carater oportunista e podem, assim, cau sar infecções graves em pacientes debilitados. Deví do à sua ubiquidade, ē muito difícil sugerir de que 
modo essa levedura foi introduzida nas piscinas $B$ e E (Quadros Nọs 07 e 11 , anexo I).

Epēcies dos gēneros Cryptococcus e Saccharo myces, fungos oportunistas, tèm sido encontradas em ambientes aquāticos, com frequéncia variāvel segundo a espécie. Organismos saprōfitas do gēnero Pichia foram também descritos em ambientes aquáticos. Cepas desses gēneros foram isoladas, apenas uma vez, de amostras diferentes (piscinas: C, D, F) Quadros Nos 08, 09 e 11, anexo I. Por essa razão, não foram con sideradas de maior interesse neste trabalho.

Dentre os parāmetros físico-químicos, $0 \mathrm{pH}$ $\bar{e}$ um dos fatores de influéncia sobre o crescimento de leveduras. De acordo com HAGLER (1978) $520 \mathrm{pH}$ ótimo situa-se entre 4,5 e 6,5 , apesar de LODDER $(1970)^{58}$ ressaltar que leveduras, em geral, crescem em ampla faixa de $\mathrm{pH}$.

Em nossa pesquisa foi notado que as levedu ras se desenvolveram em amostras de ägua com pH va riando de 6,5 a $>8,2$ (Quadro NQS 07 a 12, anexo I). Foi interessante verificar que $C$. albicans suportou valores altos de $\mathrm{pH}$, tendo sido isolada nos pontos 01 e 02 da piscina $G$, no mês de dezembro, quando o $\mathrm{pH}$ da āgua foi $>8,2$, conforme está inserido no Qua dro Nọ 12, do anexo I. A capacidade de resistência a pH alcalino de Candida parapsizopsis isolada de àgua do mar com $\mathrm{pH} 9,5$, estā relatada em trabalho de HAGLER $(1978)^{52}$.

Pelo Quadro No 12, do anexo I, pode ser observado que espēcies de outros gēneros como Aureoba sidium e Trichosporon tambēm suportam pH acima de 
8,2. Foi verificada a resistência de Trichosporon sp a pH alcalino, porém em muito relacionada à con centração de $\mathrm{NaCl}$ do meio (HAGLER, 1978) 52 . A sobre vivência de Aureobasidium sp em pH bāsico foi compro vada em estudos com ägua do mar, cujo $\mathrm{pH}$ tende a ser $8,0( \pm 0,5)($ HAGLER, 1978) 52 .

Espēcies dos gēneros Rhodotorula, Toruzopsis, Saccharomyces e Crytococcus foram isoladas de àguas com pH variando de 6,8 a 7,5 (Quadros de Nọs 07 a 11 , anexo, I). Verificou-se que Pichia sp suportou pH 6,8 (Quadro No 11 , anexo I), apesar de se ter refe rência sobre o isolamento de Pichia sp que não conse guiu crescer em condições de $\mathrm{pH} 7,36-8,26( \pm 0,3)$ (HAGLER, 1978) 52 .

Como não foi encontrada na literatura consul tada nenhuma revisão sobre a influência do $\mathrm{pH}$ de āguas de piscinas no desenvolvimento de leveduras, os dados consultados referem-se a pesquisas em àgua do mar.

Quanto ao cloro, pelos Quadros de NOS 07 a 12, anexo I, pode-se notar que em nenhuma amostra onde houve crescimento de leveduras foi detectado clo ro residual livre na ägua.

o poder desinfetante do cloro é conhecido de longa data, porēm, em relação a fungos não foi a in da estabelecida a concentração mĩnima recomendada pa ra àguas de piscinas (AMERICAN PUBLIC HEALTH ASSOCIA TION, 1980) $)^{2}$.

Segundo pesquisas de KRAUS e TIEFENBRUNNER $(1975)^{57}$, fungos patogénicos foram evidenciados so mente em amostras de água de piscina com conteūdo de 
cloro residual livre $<0,35 \mathrm{mg} / 1$ (DPD). Estudos tēm demonstrado que, para a destruição adequada de $C$. a $\underline{Z}$ bicans e desinfecção satisfatōria de āgua de piscina, são necessários, pelo menos, $1,5 \mathrm{mg} / 1$ de cloro resi dual livre (VELEGRAKIS, 1981) 92.

Em $1981^{1}$, AHO e HIRN concluiram que o nivel de cloro residual livre recomendado para controle de bactērias deve ser o mesmo para fungos patogénicos em àguas de piscinas. Analisando os resultados, foi verificado que na amostra de āgua da piscina $A$, onde a concentração de cloro residual livre era de 0,4 $\mathrm{mg} / 1$ (OTA) e o NMP $/ 100 \mathrm{ml}$ de bactérias < 2 (ausente) Quadro Nọ 05, anexo I, não houve crescimento de leve duras (Quadro Nọ 06, anexo I), confirmando, assim, as observações dos autores anteriormente citados.

As leveduras têm, em sua maioria, temperatu ra ötima de crescimento entre 20 e $28^{\circ} \mathrm{C}$ (LODDER, 1970) ${ }^{50}$. Em nosso trabalho, foram isoladas leveduras a partir de águas com valores de temperatura oscilan do entre 19 e $28^{\circ} \mathrm{C}$ (Tabela No 01 , anexo II), sendo observado que entre 25 e $28^{\circ} \mathrm{C}$ houve crescimento de maior variedade de espécies.

Em relação à turbidez, parece que não houve relação com o desenvolvimento de leveduras, visto que espécies dos diversos géneros, na maioria das vezes, foram isoladas de àguas dentro dos limites preconiza dos.

A existência de banhistas, aparentemente, não proporcionou aparecimento de leveduras na água, com exceção de $C$. azbicans qeu foi isolada de amostras quando havia usuārios na piscina. 
A ocorrēncia de chuvas nas 24 horas anterio res às coletas de amostras pode ter contribuido para - encontro do maior número de espécies de diversos gêneros, pois algumas delas foram isoladas somente nessa situação. A penetração de āgua de enxurradana piscina $F$, no més de dezembro, pode ter contribuido para o arraste de detritos, partículas do solo e ve getais, carreando, desse modo, leveduras para dentro do tanque. Esta hipōtese está baseada nos resulta dos positivos encontrados (Quadro No 11, anexo I). nesse mês, nas amostras de āgua dessa piscina.

\subsubsection{Fitoplāncton}

Como jā foi anteriormente comentado, em ge ral, em águas de piscinas os problemas originados pe la proliferação de algas são de ordem estética (BRANCO e PEREIRA, 1975) 14.

Entre os microrganismos que vivem fixos às paredes das piscinas, predominam as algas, formando - chamado "limo", escorregadio, em virtude da grande quantidade de matéria gelatinosa que secretam e que as protege contra a ação de algicidas (BRANCO e PE REIRA, 1975$)^{14}$.

As algas nas piscinas podem aparecer sob duas formas, flutuantes ou aderentes ao fundo e paredes da piscina. Sua presença traz uma sērie de inconve nientes, por exemplo, por serem de natureza orgāni ca, aumentam a demanda de cloro; tornam escorrega dias as paredes e o fundo das piscinas, aumentando a possibilidade da ocorrência de acidentes; em presen 
ça de cloro, provocam odores que podem ser percebi dos pelos banhistas: podem favorecer o crescimento de bactérias, pois pela alta demanda que provocam, protegem as bactērias da ação do cloro (ANDRADE e MO REIRA, 1975$)^{3}$.

A constante manutenção de cloro residual li vre na àgua de piscina $\bar{e}$ indicada para previnir o crescimento de algas (BLACK e col., 1970)10. Uma do sagem de $1,0 \mathrm{mg} / 1$ de cloro residual livre manterá a piscina livre de algas (CETESB, 1983) ${ }^{24}$.

Para eliminar os organismos do fitoplāncton, - sulfato de cobre pode ser usado na dosagem de 1,0 a $1,5 \mathrm{mg} / 1$, mas exige cuidado e è de difícil contro le, podendo trazer problemas como produção de precí pitado colorido de sulfato de cobre, se existir na àgua gās sulfídrico $\left(\mathrm{H}_{2} \mathrm{~S}\right)$, e pode descorar o cabelo e a roupa de banho dos nadadores. Grandes quantida des de sulfato de cobre ressecam as mucosas (ANDRADE e MOREIRA, $1975 j^{3}$.

MUCHMORE (1978) ${ }^{66}$ discute que o mëtodo de tra tamento preferido parece ser a utilização do sulfato de cobre, porque é econōmico e eficaz. No entanto, segundo ANDRADE e MOREIRA $(1975)^{3}$, "as piscinas nas quais se mantém, constantemente, um residual de clo ro livre e uma recirculação adequada, terão poucos problemas com algas. A melhor solução para esse pro blema é a cloração e a recirculação continuada duran te as 24 horas do dia. 0 problema das algas aparece quando o operador diminui a cloração e interrompe a filtração por algum tempo".

Acredita-se que a atenção de um operador cuI 
dadoso e consciencioso, o que frequentemente falta, $\bar{e}$ o mais importante fator para manter uma piscina sem turbidez elevada e nos limites de potabilidade da āgua (BLACK, 1970)11.

Nas piscinas pesquisadas foram observadas es pécies de quatro gêneros de algas, o que pode ser ob servado na Tabela Nọ 05, do anexo II. Esses organis mos praticamente só foram encontrados no material de raspado das paredes, "limo". Pelos Quadros de Nos 06 a 12 este fato pode ser verificado.

Na piscina C (Quadro no 08, anexo I), que ti nha revestimento de resina sintētica, como foi carac terizada no Quadro Nọ 01 , do anexo I, não foi coleta do material da parede. Foi observado durante as cole tas que as piscinas recobertas de azulejos apresenta ram grande quantidade de matéria orgānica na junção dos mesmos.

Organismos do gēnero Oocystis foram observa dos, no mês de março, em amostras da àgua e do raspa do das paredes da piscina G (Quadro Nọ 12, anexo I). Fazendo-se uma anālise geral dos Quadros de Nọs 06 a 12, pode-se verificar que esta foi a única vez que as algas foram encontradas em amostras da àgua.

A importāncia e o significado sanitārio das espēcies dos géneros encontrados no raspado das pare des de quase todas as piscinas foram baseados nas pes quisas de BRANCO e col., $(1963)^{15}$, com as caracterís cas que se seguem.

Calothrix spp (algas azuis) são encontradas em àgua limpa. Fixam-se pela parte basal a rochas e ou tros substratos imersos. Resistem à maioria dos alga 
cidas, inclusive a altas dosagem de sulfato de cobre. São sensivveis ao C.M.U. $(3(p-c l o r o f e n i l)-1,1$ dimetil urēia).

oscizlatoria spp (algas azuis), em geral, não são de superfície, vivendo de preferéncia no fundo de pequenas poças. Vārias espécies causam obstrução de filtros. Quando em grande nūmero, na āgua, ıcausam odor de grama ou de temperos. Algumas espécies po dem ser encontradas presas às paredes de reservató rios. Podem causar corrosão do ferro e produzir li mo. São sensíveis ao sulfato de cobre e resistentes ao cloro.

Oocystis spp (algas verdes) são algas de su perficie, podendo existir em grande nümero em lagos ou pequenas lagoas ou poços. Resistem à maioria dos algicidas, inclusive ao sulfato de cobre. São sensi veis do D.A.C. (cloreto de dodecil acetamido dimetil benzil amōnia).

Scytonema spp (algas azuis) são pouco fre quentes as que vivem na āgua. Em geral, vivem no so 10, paredes e pedras úmidas e outros ambientes subaéreos. Nada foi descrito quanto à sua resistēncia a algicidas.

\subsubsection{Amebas de vida livre}

As amebas do gēnero Hartmannezla foram as únicas encontradas em todas as piscinas (Tabela No 06, do anexo II). Este dado concorda com outros acha dos de autores em diversas regiōes do mundo, pois es tas amebas são de encontro frequente em coleçōes de 
àgua. (DERR-HARF e col., $1978^{32}$; PERNIN e RIANY, 1978) ${ }^{76}$. Embora não sejam consideradas patogēncias, sua importāncia não pode ser afastada. Haja visto o relato de encontro em secreção de faringe (WANG e FELDMAN, 1967) 95 , com possibilidade de adaptação à espēcie humana e pela provāvel etiologia de caso de meningoencefalite descrito no Brasil (FORONDA, 1976) ${ }^{3}$. outro dado a ser considerado é o fato de muitos auto res divergirem quanto à terminologia e $\bar{a}$ distinção taxionômica entre os gêneros Hartmannezza e Acantha moeba, havendo casos de meningoencefalite relatados na literatura como sendo por Hartmannezza sp, não se sabendo qual a verdadeira etiologia.

As amebas realmente consideradas como agen tes etiolōgicos de doenças humanas, dos gêneros Nae gleria e Acanthamoeba, foram encontradas em trēs pis cinas (A, D e F) a partir de quatro amostras, em ca so de Naegzeria spp, e em três (A, B e F) a partir de quatro amostras, em caso de Acanthamoeba spp (Qua dros Nos $6,7,9$. e 11, anexo I). Em duas delas (A.e F), foram encontradas amebas dos dois gēneros, embo ra em ocasiões diferentes (Tabela Nọ 06, anexo, II).

Quase sempre em que foi assinalada a presen ça de Naegleria sp ou Acanthamoeba sp, tambēm se ve rificou contagem padrão de bactérias elevada.

A concentração de cloro residual livre foi quase sempre inexistente e na ūnica vez em que se aproximou do mīnimo recomendāvel $(0,5$ a $0,8 \mathrm{mg} / 1)$, foi na piscina $A$, em abril de 1.981 , no valor de 0,4 $\mathrm{mg} / 1$. Esta concentração impediu, aparentemente, o crescimento de bactérias e leveduras, mas não 0 de 
Naegleria sp, concordando com os experimentos de DERREUAUX e col., $(1974)^{31}$, in vitro, que observaram efeito de àcido hipocloroso sobre Naegzeria sp na concentração mĩnima de $0,5 \mathrm{mg} / 1$.

0 encontro de amebas potencialmente patogēni cas foi verificado numa faixa de $p H$ entre 6,8 e 8,2 . Este dado era esperado, uma vez que as amebas de vi da livre, embora com crescimento ótimo em meios com pH em torno de 7,0 tambēm se desenvolvem em ambien tes sujeitos a variações amplas de $\mathrm{pH}$ (entre 4,6 e $9,5$, segundo CARTER, 1970$)^{20}$.

A partir do raspado das paredes foram isola das cepas de NaegZeria sp em trés amostras, num to tal de quatro, sendo que a única amostra positiva da āgua livre foi na mesma piscina e na mesma ocasião em que apareceram também no raspado. Em Acanthamoeba $s p$, do total de quatro amostras, duas foram do raspa do e duas da āgua, em ocasiões diferentes. 0 mate rial do raspado, provavelmente de origem orgãnica, deve ter funcionado como elemento multiplicador dos protozoārios.

A temperatura da āgua, nos achados de Naegle ria sp, esteve sempre entre 25 e $27^{\circ} \mathrm{C}$, confirmando a opinião de vārios autores sobre a termofilia deste grupo de protozoārios (GRIFFIN, 197251; DE JONCKHEERE e VAN DE VOORDE, 1977) ${ }^{30}$. Naegleria fowleri, a ūni ca espécie de Naegzeria considerada patogênica para - homem, tem nîtida preferéncia para āguas biologica mente saudāveis e mantidas a niveis elevados de tem peratura. Piscinas aquecidas e àguas submetidas à polição térmica podem ter grande importância na pró 
liferação desta espécie. E interessante salientar que estas amebas se multiplicam muito bem atē niveis em torno de $40^{\circ} \mathrm{C}$. Foi considerado oportuno citar es tes fatos, embora neste trabalho não tenha sido fei ta a identificação específica, nem realizados testes de patogenicidade com as cepas isoladas.

Nos achados de Acanthamoeba sp a temperatura da āgua esteve entre 21 e $28^{\circ} \mathrm{C}$. Não hã relato na lí teratura sobre a temperatura ideal de crescimento na natureza, embora em laboratōrio a temperatura de $28^{\circ} \mathrm{C}$ seja a recomendada.

As piscinas $D$ e $F$, onde foram encontradas NaegZeria sp e Acanthamoeba sp, não possuem fil tros. Embora estas espécies tenham sido encontradas em piscinas com filtro, a melhoria deste sistema pa rece ser de grande importāncia no controle destes protozoārios.

$\mathrm{Na}$ piscina $F$ foram encontrados, em todas as coletas, Pseudomonas seruginosa, coliformes totais, contagem padrão elevada e algas no raspado das pare des, caracterizando condições gerais de deficiência de tratamento.

Embora não tenha sido possivel a identifica ção específica das amebas, o encontro de exemplares do mesmo género das patogénicas é importante porque as condiçōes ecolōgicas exigidas por espēcies do mes mo gênero podem ser semelhantes, salientando-se o fa to de que essas amebas são ainda consideradas de vi da livre, com opção para a vida parasitāria. Como as sinala FORONDA $(1979)^{39}$, podemos estar diante de al gumas espēcies patogēnicas ou diante de um complexo 
de protozoārios em transição para a vida parasitā ria, transição essa que não pode ser avaliada em es tudo como este.

Pretendeu-se, neste trabalho, apenas verifi car a prevalēncia de amebas de vida livre em pisci nas de Campo Grande e chamar a atenção para o proble ma potencial deste grupo de protozoários em Saūde Pú blica. 
5. CONCLUSOES E RECOMENDAÇOES 
Durante a realização do trabalho, pratị camente, não foi detectada a presença de cloro residual, a não ser em três das amostras, quando este bactericida foi encontrado em concentração menor do que $0,5 \mathrm{mg} / 1$, valor este que constitui o mínimo preconizado para a se gurança sanitāria. Paralelamente, o pH teve oscilações, ficando abaixo e acima de 6,7 e 7,9 , faixa recomendada pela Norma Técnica de Ãgua (NTA-60), do Estado de São Paulo. Já a turbidez ultrapassou apenas uma vez os $1 \underline{i}$ mites de 2-5 NTU da Norma Técnica de Āgua (NTA-60). Ou tros parámetros físico-químicos mantiveram-se dentrodos limites de toleráncia, tais como: cor $=10-20 \mathrm{mg} / 1 \mathrm{Pt} / 1$ alcalinidade $\left(\mathrm{mg} / \mathrm{l}-\mathrm{CaCO}_{3}\right)$ em Hidrōxido = zero, em Carbonato $=120$, em Bicarbonato $=250 ;$ cloretos $=250$ $\mathrm{mg} / \mathrm{r}-\mathrm{Cl}$.

Quanto aos microrganismos, foi verifica do que os coliformes totais estavam presentes em $57,1 \%$ das piscinas estudadas e os coliformes fecais em $42,9 \%$. Pseudomonas aeruginosa foi isolada, praticamente, com a mesma freqüéncia do que os coliformes totais. Estrepto cocos fecais raramente foram encontrados. A contagem pa drão em placas quase sempre foi superior a 300 coló nias/ml, nümero minnimo aceitável.

As algas foram evidenciadas nas amostras de raspado das paredes das piscinas revestidas de azule jos e em uma amostra de āgua. As espécies do gēnero oscizzatoria foram observadas em praticamente todas as piscinas $(85,7 \%)$.

As leveduras só não foram detectadas em uma piscina. Espēcies dos gēneros Candida e Aureobasi dium foram as mais encontradas, em $85,7 \%$ das piscinas. 
Em amostras de āgua de duas piscinas foi encontrada can dida albicans, organismo oportunista, atualmente sendo proposto como indicador de poluição fecal recente em am bientes aquāticos.

Amebas de vida livre foram isoladas de to das as piscinas pesquisadas, sendo que espécies dos gê neros Naegleria e Acanthamoeba, potencialmente patogén cas, foram detectadas em amostras de trēs das piscinas es tudadas.

Com base nesses resultados conclui-se que:

- a operação e manutenção das piscinas es tudadas não estão sendo adequadas;

- os valores do pH e do cloro residual mui tas vezes apresentaram-se fora dos limites preconizados e, como era de se esperar, evidenciou-se serem estes fa tores de grande importáncia no que diz respeito ao con trole de microrganismos.

- os microrganismos ocorreram em todas as piscinas e o indice de coliformes, em geral, esteve aci ma dos limites tolerāveis para àgua potāvel.

Em virtude das piscinas pesquisadas apre sentarem condições sanitārias inadequadas e risco poten cial à saūde dos usuārios, recomenda-se que:

- o controle bacteriano seja feito pelo menos uma vez por més ou quando houver suspeita de polui ção da āgua, utilizando-se sempre mais do que um organismo como indicador, com a finalidade de confirmar re sultados ou dirimir dūvidas; 
- a pesquisa de algas, leveduras e amebas de vida livre seja realizada, pelo menos, duas vezes ao ano ou quando as condiçōes do ambiente exigirem. A es pecificação dessa periodicidade prende-se ao fato de não haver disponibilidade local de pessoal técnico espe cializado;

- sejam realizados cursos de tratamento

de àgua de piscina para os operadores;

- seja estabelecida legislação Estadual fixando os limites dos parāmetros físico-químicos e mi crobiológicos a serem seguidos;

- sejam praticados os princípios bāsicos de educação em saūde, não só por usuārios, como tambēm por administradores e operadores das piscinas. 
6. REFERENCIAS BIBLIOGRĀFICAS 
1. AHO, R. \& HIRN, J. - A survey of fungi and some indicator bacteria in clorinated water of in door public swimming pools. Zbl. Bakt. Hyg., I. Abt. Orig. B., 173: 242-249, 1981 .

2. AMERICAN PUBLIC HEALTH ASSOCIATION. - Standard methods for examination of water and wastewater. 15 th, New York, 1980.

3. ANDRADE, M.G.P. \& MOREIRA, M.C. - Operação e manŭ tenção de piscinas. In: Piscinas de uso coletị vo. 2a.ed. São Paulo, BNH/ABES/CETESB, 1975. p. $183-216$.

4. AZEVEDo NETTO, J.M. de. - Alcalinidade e dureza das āguas, controle de corrosão. In: TECNICA de abastecimento e tratamento de āgua. 2a.ed. São Paulo, CETESB, 1979. v.2, p. 931-938.

5. AZEVEDO NETTO, J.M. de. - Desinfetantes principais. Ação bactericida do cloro. Diōxido de cloro. Iodo. Ozona. Raios ultra-violeta. In: SECRETARIA DOS SERVIÇOS E OBRAS PUBLICAS. Desinfecção de àguas. São Pau1o, CETESB, 1974. p.19-28.

6. AZEVEDO NETTO, J.M. de. - Hidráulica das piscinas. In: PISCINAS de uso coletivo. São Paulo, CETESB, 1975. p. 81-95.

7. BABBIT, H.E. et al. - Abastecimento de àgua. São Paulo. Edgard B1ücher, 1962. p. 362-384.

8. BICUDO, C.E.M. \& BICUDO, R.M.T. - Algas de āguas continentais brasileiras. São Paulo, Fundação Brasileira para o Desenvolvimento do Ensino de Ciências, 1970.

9. BIER, 0.G. - Bacteriologia e imunologia em suas aplicações à medicina e à higiene. 19a.ed. São Paulo, Melhoramentos, 1978. 
10. BLACK, A.P. et a1. - The desinfection of swimming pool waters. Part. I. Comparison of iodine and chlorine as swimming pool desinfectants. Amer. J. publ. H1th., 60: 535-545, 1970.

11. BLACK, A.P. et a1. - The desinfection of swimming pool water. Part II. A field study of the disin fection of public swimming pools. Amer. J. publ. H1th, 60: 740-750, 1970 .

12. BOURRELLY, P. - Les algues vertes. In: Les algues d'eau douce: initiacion à la systématique. Pa ris, N. Boubée, 1966. v.1.

13. BRANCO, S.M. - Hidrobiologia aplicada a engenharia sanitária. 2a. ed. São Paulo, CETESB, 1978.

14. BRANCO, S.M. \& PEREIRA, H.A.S.L. - Características biológicas da āgua de piscinas. In: PISCINAS de uso coletivo. 2a. ed. São Paulo, BNH/ABES/ CETESB, 1975. p. 39-51.

15. BRANCO, S.M. et al. - Identificação e importāncia dos principais gēneros de algas de interesse pa ra o tratamento de àguas e esgotos. Rev. D.A.E. $(48 / 50): 39-76 ; 77-84 ; 87-98,1963$.

16. BROWN, M.R.W. \& FOSTER, J.H.S. - A simple diagnos tic milk medium for Pseudomonas aeruginosa. $\mathrm{J}$. clin. Pathol., 23: 172-177, 1970.

17. BUCK, J.D. - Candida albicans. In: BACTERIAL indi cators-health hazards associated with water: a symposium. Philadelphia, Pa., American Society for Testing and Materials, 1977. p. 139-47.

18. CABELLI, V.J. et a1. - Pseudomonas aeruginosa fecal coliform relationships in estuarine and fresh recreational waters. J. Wat. Pollut. Control. Fed., 48: 367-76, 1976. 
19. CABO RAMON, J. et al. - Bacteriologia y potabili dad del agua. Madrid, Imprenta de la Bolsa, 1972 .

20. CARTER, R.F. - Description of a NaegZeria sp. iso lated from two cases of primary amoebic meningo encephalitis, and of the experimental pathologi cal changes induced by it. J.Pathol., 100: $217-244,1970$.

21. CHRISTENSEN, W.B. - Urea decomposition as a means of differentiating Proteus and Paracozon cultu res from each other and from sazmonezza and Shigezza types. J. Bact., 52: 461-466, 1946.

22. CLAUSEN, E.M. et al. - Fecal streptococci: indica tors of pollution. In: BACTERIAL indicatorshealth hazards associated with water: a sympo sium. Philadelphia, Pa., American Society for Testing and Materials, 1977, p. 247-64.

23. COMPANHIA DE TECNOLOGIA dE SANEAMENTO AMBIENTAL CETESB. - Critērios para seleção de parāmetros fĩsico-químicos na caracterização de āguas para consumo humano. In: CRITERIOS para seleção e interpretação de anāilises físico-químicas de àgua. São Paulo, 1983. (Mimeografado)

24. COMPANHIA de teCnOLOGia de SANEAMENTO AMBiental CETESB. - Operação manutenção e tratamento de āgua de piscinas. São Paulo, 1983. (Mimeogra fado)

25. CORDONNIER, $V$. et al. - Enquēte sur les champignons de piscine dans la région du Nord. Bull. Soc. Franc. Dermat. Syph., 77: 170-175, 1970.

26. CULBERTSON, C.G. - Amebic miningoencephalitis. Antibiot. Chemother., 30: 28-53, 1981. 
27. DECRETO No 12.342, de 27 de setembro de 1978. Apro va o Regulamento a que se refere o artigo 22 do Decreto-Lei 211 , de 30 de março de 1970, que dis põe sobre normas de promoção, preservação e re cuperação da saūde no campo da competéncia da Secretaria de Estado da Saūde. Leis e Decretos Est. S. Paulo, (5-pt 1): 1643-4, 1978.

28. DECRETO No 12.486, de 20 de outubro de 1978. Aprova normas técnicas especiais relativas a alimen tos e bebidas. Leis e Decretos Est. S. Paulo, (5-pt.2): 2051-2, 1978 .

29. DECRETO Nọ 13.166, de 23 de janeiro de 1979. Apro va norma técnica especial (NTE) relativa a pis cinas. Leis e Decretos Est. S.Paulo, (jan.): 125 $-132,1979$.

30. DE JONCKHEERE, J. \& VAN DE VOORDE, H. - The distri bution of Naegleria fowleri in man made thermal waters. Amer. J. trop. Med. Hyg., 26: 10-15, 1977.

31. DERREUMAUX, A.L. et al. - Action du chlore sur les amibes de 1'eau. Ann. Soc. Belge Med. Trop., 54: 415-428, 1974 .

32. DERR-HARF, C. et al. - Epidémiologie des amibes libres dans les eaux de Strasbourg. Ann. Parasit., 53: 467-477, 1978 .

33. DUTKA, B.J. - Coliforms are an inadequate index of water quality. J.environ. H1th., 36: 39-46, 1973.

34. DUTKA, B.J. \& SHERRY, J.- Pathogens as indicators of water quality. 1. Candida albicans. 2. Pseu domonas aeruginosa. Burlington, Ontario, $\mathrm{Na}$ cional Water Research Institute/Canada Centre for In Iand Waters, 1978. (Mimeografado) 
35. EXNER, M. \& HAVENITH, N. - Mikrobiologische untersuchungen an kleinwarmwasserbecken und hot-whirl-pools. Zbl. Bakt. Hyg., I. Abt. Orig. B, 173: 250-259, 1981 .

36. FLOREZ, E. et al. - Aislamiento de agentes micotí cos en uma piscina de la ciudad de Meddlin. Antioquia med., 26: 427-436, 1976.

37. FORATTINI, 0.P. - Aspectos epidemiológicos relatí vos às piscinas. In: PISCINAS de uso coletivo. 2a. ed. São Paulo, CETESB, 1975. p.13-26.

38. FORONDA, A.S. - Crescimento de amebas de vida li vre em meios semeados com líquido cefaloraquidi ano humano: nota prévia. Rev. paul. Med., 87: $140,1976$.

39. FORONDA, A.S. - Observações sobre amebas de vida livre potencialmente patogênicas, São Paulo, 1979. ITese doutoramento - Instituto de Ciên cias Biomédicas da Universidade de São Paulol.

40. FOSTER, D.H. et al. - A critical examination of bathing water quality standards. J. Wat. Pollut. control Fed., 43: 2229-2241, 1971 .

41. FOWLER, M. \& CARTER, R.F. - Acute pyogenic meningi tis probably due to Acanthamoeba sp : a prelimi nary report. Brit. Med. J., 2: 740-742, 1965.

42 GELDREICH, E.E. - Applyng bacteriological parameters to recreational water quality. J. Amer. Wat. Wks. Ass., 62: 113-120, 1970.

43. GELDREICH, E.E. - E. coli vs. fecal coliform: a definition. |Presented at the Fourth Food Micro biology Research Conference, Chicago, Illinois, 19751 . 
44. GELDREICH, E.E. - Fecal coliform concepts in stream pollution. |Presented at Symposium on Microbial Parameters of Water Pollution, New York, American Society for Microbiology Meeting, 1967|.

45. GELDREICH, E.E. - Is the total count necessary. |Present at the AWWA firt water quality Technico logy Conference, Cincinnati, Ohio, 1973/.

46. GELDREICH, E.E. - Qualidade microbiológica em āguas potāveis. In: SECRETARIA DOS SERVIÇOS E OBRAS PUBLICAS. Desinfecção de àguas. São Paulo, CETESB, 1974, p. 73-93.

47. GELDREICH, E.E. - The use and abuse of fecal streptococci in water quality measurements. IPresented at the American Society for Microbiology Annual Meeting, Boston, Massachusetts, 1970l.

48. GELDREICH, E.E. \& KENNER, B.A. - Concepts of fecal streptococci in stream pollution. J. Wat. Pol:lut. control Fed., 4l: 336-352, 1969.

49. GIROULT, E. - La calidad del agua potable. Cron. OMS, $31: 353-7,1977$.

50. GRIFFIN, J.L. - Pathogenic free-living amoebae. In: KREIR, J. Parasit. protozoa. London, Academic Press, 1977. v.2, cap. 6, p. 507-49.

51. GRIFFIN, J.L. - Temperature tolerance of pathogenic free-living amoebas. Science, 178: 869-870, 1972 .

52. HAGLER, A.N. - Ecologia e taxonomia de leveduras em um estuário poluido e ambientes marinhos do Rio de Janeiro. Rio de Janeiro, 1978. ITese de doutoramento - Instituto de Microbiologia da UFRJ I. 
53. HELMER, R. - La lucha contra la contaminación del agua. Cron. OMS, 29: 465-72, 1975.

54. HOADLEY, A.W. - On the significance of Pseudomonas aeruginosa in surface waters. J. New Engl. Wat., 82: $99-111,1968$.

55. HOADLEY, A.W. \& KNIGHT, D.E. - External otitis among swimmers and nonswimmers. Arch. environm. H1th., 30: 445-448, 1975.

56. KENNER, B.A. - Fecal streptococcal indicators. In: Indicator of viruses in water and food. Ann Arbor, Ann Arbor Science, 1978. p. 147-169.

57. KRAUS, H. \& TIEFENBRUNNER, F. - Stichprobenartige uberprüfemg einzelner tiroler schwimmbäder auf das Vorkommen von Trichomonas vaginalis und von pathogenen pilzen. Zbl. Bakt. Hyg., I.Abt. Orig. B, 160: 286-291, 1975 .

58. LODDER, J. - The yeasts: a taxonomic study. 2 a. ed. Amsterdam, North-Holland, 1970.

59. MALLMANN, W.L. - Cocci test for detecting mouth and nose pollution of swimming pool water. Amer. J. publ. H1th., 52: 2001-2008, 1962.

60 - MALLMANN, W.L. - Streptococcus as an indicator of swimming pool pollution. Amer. J. publ. H1th., 18: $771-776,1928$.

61. MANFRINI, C. - Ação bacteriana do cloro. Reações do cloro na àgua. Reações com a amōnia. Tipos de residuais. In: SECRETARIA DOS SERVIÇOS E OBRAS PJBLICAS. Desinfecção de ãguas. São Pau 10, CETESB, 1974. p. 47-71.

62. MARTINEZ, A.J. - Free-living amoebae: pathogenic aspects a review. Protozool. Abstr., 7: 293$306,1983$. 
63. MENDONÇA, C.P. \& RUFF, S.D. - Estudo das condições sanitārias das āguas de piscinas pūblicas e par ticulares na cidade de Araraquara. São Paulo, Brasil. Rev. Saūde pūbl., São Paulo, 12:113-21, 1978.

64. MINISTERIO DO INTERIOR. - Portaria no 536, de 07 de dezembro de 1976. Diārio Oficial União, 29 dez. 1976. p. 16.973 .

65. MOOD, E.W. - Effect of free and combined available residual chlorine upon bacteria in swimming pools. Amer. J. publ. H7th., 40: 459-466, 1950.

66. MUCHMORE, C.B. - Algae control in water-supply. J. Amer. Wat. Wks. Ass., 70: 273-279, 1978.

67. NORMALIZAÇÃo tēcnica - L5.201. - Contagem padrão de colónias de bactérias. São Paulo, CETESB, 1978.

68. NORMALIZAÇĀo técnica - L5.202. - Determinação do nūmero mais provāvel de coliformes totais e fe cais pela técnica dos tubos mūltiplos. São Pau 10, CETESB, 1978.

69. NORMALIZAÇÃo tēcnica - L5.205. Determinação do N.M.P. de estreptococos fecais pela técnica dos tubos mūitiplos. São Paulo, CETESB, 1978.

70. NORMALIZAÇĀo tēcnica - L5.220. Determinação do nú mero mais provāvel de Pseudomonas aeruginosa pela técnica dos tubos mūitiplos. São Paulo, CETESB, 1979 .

71. OLIVEIRA, W.E. - Saneamento de piscinas. In: PIS CINAS de uso coletivo. 2a. ed. São Paulo, CETESB, 1975, p. $1-11$. 
72. PAGE, F.C. - An illustrated key to freshwater and soil amoebae: with notes on cultivation and eco logy. Ambleside, Cumbria, Ferry House, 1976. Freshewater Biological Association - Scientific Publication, 341 .

73. PALMER, C.M. - Algas en abastecimientos de agua. México, Editorial Interamericano, 1962. p.5.

74. PALMER, C.M. \& INGRAM, W.M. - Suggested classifica tion of algae and protozoa in sanitary science. Sew. Indust. Wast., 27: 1183-88, 1955.

75. PERA, A.F. - Características físicas, químicas e bacteriolōgicas da āgua de piscinas: padrões, cloro residual. In: PISCINAS de uso coletivo. 2a. ed. São Paulo, CETESB, 1975. p. 27-37.

76. PERNIN, P. \& RIANY, A. - Etude sur la presence d' "amibes libres" dans les eaux des piscines Tyonnaises. Ann. Parasitol., 53: 333-343, 1978.

77. PRESCOTT, G.W. - Algae of the westerngreat lakes area. Dubuque, Iowa, W.M.C. Brown, 1962.

78. RAMOS, $Z$. - Estudo qualitativo de algas em pisci nas. São Paulo, 1970. Dissertação de Mestrado - Faculdade de Saũde Pūblica da Universidade de São Paulol.

79. REINHARDT, N.M. - Condições sanitārias das àguas de poços rasos da área não servida pela rede de abastecimento pūblico de àgua do município de Curitiba, Paranā, 1975. São Paulo, 1977. |Dissertação de Mestrado - Faculdade de Saúde Pública da Universidade de São Paulol.

80. RIPPON, J.W. - Medical mycology the pathogenic fungi and the pathogenic actinomycetes. $2 a$. ed. Philadelphia, Saunders, 1982. 
81. RIVALIER, E. \& SEYDEL, S. - Cultures minces sur lames gelosēes, colorēes et examinēes in situ en preparations définitives, pour l'ētude des cryptogames microscopiques. C.R. Soc. Biol., 110: $181-184,1932(\mathrm{a})$.

82. ROBINTON, E.D. et al. - A study of bacterial flora in swimming pool water treated with high-free residual chlorine. Amer. J. publ. H7th., 47: 1101-1109, 1957.,

83. ROCHA, A.A. - Estudo sobre a fauna bentónica da re presa de Americana no Estado de São Paulo. São Paulo, 1972. Dissertação de Mestrado - Depar tamento de Zoologia do Instituto de Biociēncias da Universidade de São Paulol.

84 ROSSIN, C.R. - Desinfeç̧ão. In: TECNICA de abaste cimento e tratamento de àgua. 2a. ed. São Pauro, CETESB, 1979. v.2, p. 883-929.

85. SEYFRIED, P.L. \& FRASER, D.J. - Persistence of Pseudomonas aeruginosa in chlorinated swimming pools. Can. J. Microbiol., 26:350-355, 1980.

86. SEYFRIED, P.L. \& FRASER, D.J. - Pseudomonas aeru ginosa in swimming pools related to the inciden ce of otitis externa infection. Hith. Lab. Sci., 15: 50-7, 1978 .

87. SIMAOO, E.J. et al. - Operação e manutenção de pís cinas. Rio de Janeiro, Secretaria de obras e Serviços Püblicos/Fundação Estadual de Engenha ria do Meio Ambiente, 1977 . |Mimeografado|

88. SLANETZ, L.W. \& BARTLEY, C.H. - Detection and sanitary significance of fecal streptococci in water. Amer. J. publ. H1th., 54: 609-614, 1964.

89. SMITH, G.M. - The fresh-water algae of the United States. New York, McGraw-Hi11, 1950. 
90. SOMOSI, G. - Wichtige higienische fur schwimmbäder. Zbl. Bakt. Hyg., I. Abt. Orig. B., 173: 260-265, 1981 .

91. SOUZA, H.B. \& DERISIO, J.C. - Guia técnico de cole ta de amostras de àgua. São Paulo, CETESB, 1982 .

92. VELEGRAKIS, A. et a1. - Sensitivity of C. albicans in vitro in free-residual chlorine. Acta. Micro biol. Hell, 25: $350-361,1981$.

93. VERMEIL, C. et al. - Blastomycose cheloidienne a Aureobasidium pulzulans (De Bary) Arnaud en Bretaene. Mycopathologia, Den Haag, 43: 35-39, 1971.

94. VICTORIN, $K$. - A field study of some swimming-pool waters with regard to bacteria, available chlorine and redox potencial. J.Hyg., Cambridge, 72: 101-110, 1974 .

95. WANG, S.S. \& FELDMAN, H.A. - Isolation of Hartman nezza species from human throats. New Engl. Med., 277: $1174-1179,1967$.

96. WATER quality surveys: a guide for the collection and interpretation of water quality data. Paris, Unesco; Geneva, World Health Organization, 1978.

97. ZINGANO, A.G. - Contribuição ao estudo higiénico das piscinas de Porto Alegre. Porto Alegre, 1956. ITese de Doutoramento - Faculdade de Medi cinal 


\section{A NEXXOL I \\ (Quadros de 1 a 12)}

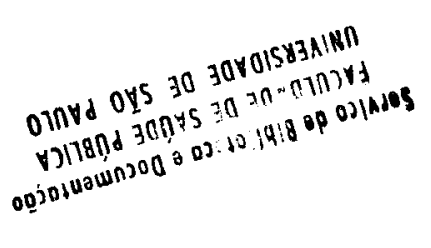




$$
\text { QUADRO } 1 \text { - CLASSIFICAÇÃO DAS PISCINAS }
$$

\begin{tabular}{|c|c|c|}
\hline CLASSIFICAÇÃO & PISCINAS & $\begin{array}{l}\text { PERCENTAGEM } \\
(\%)\end{array}$ \\
\hline Recreativas & $A, C, D, E, F$ & 71,4 \\
\hline Mistas & $\mathrm{B}, \mathrm{G}$ & 28,6 \\
\hline Recirculação e tratamento & $A, B, D^{*}, E, G$ & 71,4 \\
\hline Encher e esvaziar & $C, F$ & 28,6 \\
\hline $\begin{array}{l}\text { Natural (temperatura natu- } \\
\text { ral da agua) }\end{array}$ & $A, B, C, D, E, F, G$ & 100,0 \\
\hline Externa (ao ar livre) & $A, B, C, D, E, F, G$ & 100,0 \\
\hline Fundo liso(resina sintētica) & $\mathrm{C}$ & 14,3 \\
\hline Fundo com azulejos & $A, B, D, E, F, G$ & 85,7 \\
\hline Paredes lisas (resina sintética) & $\mathrm{C}$ & 14,3 \\
\hline Paredes de azulejos & $A, B, D, E, F, G$ & 85,7 \\
\hline
\end{tabular}

* Recirculação através de bomba externa. 
QUADRO 2 - ASPECTOS RELATIVOS AO TRATAMENTO

\begin{tabular}{|c|c|c|c|}
\hline PISCINA & PRODUTOS QUIMICOS & FINALIDADE & $\begin{array}{r}\text { FILTRO } \\
\text { PRESSÃO }\end{array}$ \\
\hline $\mathrm{A}$ & $\begin{array}{l}\text { Hipodash - líquido } \\
\text { Sulfato de alumínio } \\
\text { Sulfato de cobre } \\
\text { Carbonato de sódio }\end{array}$ & $\begin{array}{l}\text { Desinfecção } \\
\text { Coagulação } \\
\text { Algicida } \\
\text { Correção pH }\end{array}$ & $\operatorname{Sim}$ \\
\hline $\mathrm{B}$ & $\begin{array}{l}\text { HTH (Hipoclorito cálcio) } \\
\text { Sulfato de alumínio } \\
\text { Sulfato de cobre } \\
\text { Carbonato de sódio }\end{array}$ & $\begin{array}{l}\text { Desinfecção } \\
\text { Coagulação } \\
\text { Algicida } \\
\text { Correção pH }\end{array}$ & $\operatorname{sim}$ \\
\hline $\mathrm{C}$ & $\begin{array}{l}\text { HTH (Hipoclorito cálcio) } \\
\text { Sulfato de alumínio } \\
\text { Sulfato de cobre } \\
\text { Cal }\end{array}$ & $\begin{array}{l}\text { Desinfecção } \\
\text { Coagulação } \\
\text { A1gicida } \\
\text { Correção pH }\end{array}$ & Não \\
\hline D & $\begin{array}{l}\text { HTH (Hipoclorito cálcio) } \\
\text { Sulfato de alumínio } \\
\text { Sulfato de cobre }\end{array}$ & $\begin{array}{l}\text { Desinfecção } \\
\text { Coagulação } \\
\text { Algicida }\end{array}$ & Não \\
\hline $\mathrm{E}$ & $\begin{array}{l}\text { Cloro em gás } \\
\text { Sulfato de alumínio } \\
\text { Sulfato de cobre } \\
\text { Carbonato de sódio }\end{array}$ & $\begin{array}{l}\text { Desinf ecção } \\
\text { Coagulação } \\
\text { Algicida } \\
\text { Correção pll }\end{array}$ & $\operatorname{Sim}$ \\
\hline F & $\begin{array}{l}\text { HTH (Hipoclorito cálcio) } \\
\text { Sulfato de alumínio } \\
\text { Hidroquat } \\
\text { Carbonato de sódio } \\
\text { Azul de bromo timol }\end{array}$ & $\begin{array}{l}\text { Desinfecção } \\
\text { Coagulação } \\
\text { Algicida } \\
\text { Correção pH } \\
\text { Corante }\end{array}$ & Não \\
\hline G & $\begin{array}{l}\text { Cloro cal "QC" } \\
\text { Sulfato de alumínio } \\
\text { Sulfato de cobre }\end{array}$ & $\begin{array}{l}\text { Desinfecção } \\
\text { Coagulação } \\
\text { Algicida }\end{array}$ & $\operatorname{sim}$ \\
\hline
\end{tabular}


QUADRO 3 - ORIGEM DA ĀGUA U'TILIZADA NAS PISCINAS

\begin{tabular}{|c|c|c|c|}
\hline \multicolumn{2}{|c|}{ PISCINAS } & \multirow[t]{2}{*}{ ORIGEM DA ĀGUA } & \multirow{2}{*}{$\begin{array}{c}\text { PERCENTAGEM } \\
(\%) \\
28,6\end{array}$} \\
\hline A & $\mathrm{F}$ & & \\
\hline $\mathrm{E}$ & G & Poço profundo & 28,6 \\
\hline & $\mathrm{D}$ & Fonte & 28,6 \\
\hline B & & $\begin{array}{l}\text { Estação de tratamento } \\
\text { de água (ETA) }\end{array}$ & 14,2 \\
\hline
\end{tabular}


QUADRO 4 - COMPOSTOS FORMADOS PELO CLORO (VALORES DE TEMPERATURA APROXI MADOS A 200 C)

\begin{tabular}{|c|c|c|c|c|}
\hline $\mathrm{pH}$ & $\begin{array}{l}\text { CRL }(\%) \\
\text { HOCl }\end{array}$ & $\begin{array}{c}\text { CRL (\%) } \\
\mathrm{OCl}^{-}\end{array}$ & $\begin{array}{c}\mathrm{CRC}(\%) \\
\mathrm{NH}_{2} \mathrm{Cl}\end{array}$ & $\begin{array}{c}\mathrm{CRC}(\%) \\
\mathrm{NHCl}_{2}\end{array}$ \\
\hline 4,5 & 100 & 0 & 0 & 100 \\
\hline 5,0 & 100 & a & 0 & 100 \\
\hline 6,0 & 97 & 3 & 35 & 65 \\
\hline 7,0 & 75 & 25 & 55 & 45 \\
\hline 7,5 & 50 & 50 & 75 & 25 \\
\hline 8,0 & 25 & 75 & 90 & 10 \\
\hline 9,0 & 3 & 97 & 100 & 0 \\
\hline 10,0 & 0 & 100 & 100 & 0 \\
\hline
\end{tabular}

Fonte: Informação pessoal. Químico e Instrutor Técnico de Treinamento da CETESB - Orlando Bazito Filho(1984). 


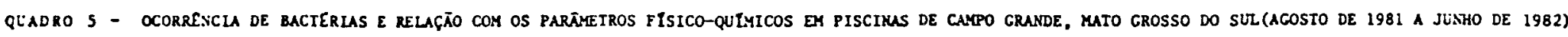

\begin{tabular}{|c|c|c|c|c|c|c|c|c|c|c|c|}
\hline PISCILAS & $\begin{array}{l}\text { PE.RTOLO } \\
\text { DE } \\
\text { CLLETA }\end{array}$ & & $\begin{array}{l}\text { ATLEA } \\
\text { C) } \\
{ }_{\text {XGUA }}\end{array}$ & pH & $\begin{array}{l}\text { TURBLDEZ } \\
\text { (ATU) }\end{array}$ & $\begin{array}{l}\text { CLORO RES LDLALL } \\
\text { LIVRE } \\
(\not g / 1)\end{array}$ & $\begin{array}{l}\text { COLIPO } \\
\text { (NMPP/1 } \\
\text { Totais }\end{array}$ & $\begin{array}{l}\text { MES } \\
\text { Om1) } \\
\text { Fecais }\end{array}$ & $\begin{array}{l}\text { P.aerugisusa } \\
\text { (NeP/10001) }\end{array}$ & $\begin{array}{c}\text { Escreptococos } \\
\text { fecais } \\
(\operatorname{MaP} / 100=21)\end{array}$ & $\begin{array}{c}\text { Contagem padrao } \\
\text { colônias/ml }\end{array}$ \\
\hline $\begin{array}{l}A \\
\vdots \\
C \\
D \\
E \\
G=\cdots+ \\
C\end{array}$ & 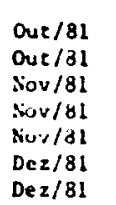 & $\begin{array}{l}27,0 \\
27.0 \\
28.0 \\
35,0 \\
33,0 \\
27,0 \\
33,0\end{array}$ & $\begin{array}{l}25,0 \\
25.0 \\
25.0 \\
28,0 \\
28,0 \\
28,0 \\
27,0\end{array}$ & $\begin{array}{r}6,6 \\
7,1 \\
7,5 \\
7,4 \\
6,8 \\
6.8 \\
>8.2\end{array}$ & $\begin{array}{l}0,6 \\
1,0 \\
2,0 \\
5,5 \\
1,3 \\
1,3 \\
0,9\end{array}$ & $\begin{array}{l}0,0 \\
0.0 \\
0.0 \\
0.0 \\
0,0 \\
0,0 \\
0.0\end{array}$ & $\begin{array}{r}23 \\
22 \\
22 \\
<\quad 2 * \\
<2 * \\
540 \\
<\quad 2 *\end{array}$ & $\begin{array}{r}<2^{*} \\
2 \\
17 \\
<2 * \\
<2 * \\
17 \\
<2 *\end{array}$ & $\begin{aligned} & 5 \\
& 5 \\
< & 2 * \\
< & 2 * \\
< & 2 * \\
& 33 \\
< & 2 *\end{aligned}$ & $\begin{array}{l}<2 * \\
<2 \\
<2 * \\
<2 * \\
<2 \\
<2 *\end{array}$ & $\begin{array}{l}>300^{* *} \\
>300^{* *} \\
24 \\
265 \\
115 \\
>300^{* *} \\
5\end{array}$ \\
\hline $\begin{array}{l}A \\
B \\
C \\
D \\
E \\
\text { C } \\
\text { C }\end{array}$ & $\begin{array}{l}\mathrm{Jan} / 82 \\
\mathrm{Jan} / 32 \\
\mathrm{Fev} / 82 \\
\mathrm{Eev} / 82 \\
\mathrm{Fev} / 82 \\
\mathrm{Mar} / \mathrm{HZ} \\
\mathrm{Mar} / 82\end{array}$ & $\begin{array}{l}23,0 \\
24,0 \\
26,0 \\
28,0 \\
29,0 \\
23,0 \\
24,0\end{array}$ & $\begin{array}{l}28,0 \\
27,0 \\
27,0 \\
27,0 \\
27,0 \\
25,0 \\
26,0\end{array}$ & $\begin{array}{r}6,8 \\
6,8 \\
7,5 \\
>8,2 \\
6,8 \\
7,0 \\
>8,2\end{array}$ & $\begin{array}{l}1,5 \\
1,5 \\
3,0 \\
2,5 \\
1,0 \\
1,0 \\
1,2\end{array}$ & $\begin{array}{l}0,1 \\
0,0 \\
0,2 \\
0,0 \\
0,0 \\
0,0 \\
0,0\end{array}$ & $\begin{aligned} & 2 \\
< & 9 \\
< & 2^{*} \\
< & 2 * \\
< & 2 * \\
130 & \\
< & 2 *\end{aligned}$ & $\begin{array}{l}<2 * \\
<2 * \\
<2 * \\
<2 * \\
<2 * \\
<2 * \\
<2 *\end{array}$ & $\begin{array}{l}<2 * \\
<\quad 2 * \\
<2 * \\
13 \\
<2 * \\
<\quad 2 *\end{array}$ & 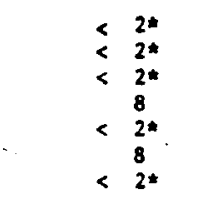 & $\begin{array}{c}1400 \\
>300 \star \star \\
300 \\
2100 \\
800 \\
84000 \\
3\end{array}$ \\
\hline $\begin{array}{l}A \\
B \\
C \\
D \\
E \\
F \\
C\end{array}$ & $\begin{array}{l}A b r / 82 \\
A b r / 82 \\
\mathrm{Mai} / 82 \\
\mathrm{Mai} / 82 \\
\mathrm{Mai} / 82 \\
\mathrm{Jun} / 82 \\
\text { Jun/82 }\end{array}$ & $\begin{array}{l}25,0 \\
26,0 \\
13,0 \\
18,0 \\
18,0 \\
20,0 \\
22,0\end{array}$ & $\begin{array}{l}25,0 \\
25,0 \\
22,0 \\
22,0 \\
21,0 \\
22,0 \\
22,0\end{array}$ & $\begin{array}{l}6,9 \\
7,5 \\
6,8 \\
7,5 \\
7.0 \\
7.0 \\
8,0\end{array}$ & $\begin{array}{l}0,9 \\
2,0 \\
= \\
= \\
=\end{array}$ & $\begin{array}{l}0,4 \\
0,0 \\
0,0 \\
0,0 \\
0,0 \\
0,0 \\
0,0\end{array}$ & $\begin{array}{l}<2^{2 *} \\
2 \\
<2 * \\
<2^{2 *} \\
<2^{*} \\
8 \\
<\quad 2 *\end{array}$ & $\begin{array}{l}<2 * \\
<2 * \\
<2 * \\
<2 * \\
<2 * \\
<2 \\
<2 *\end{array}$ & $\begin{array}{l}<2 * \\
<\quad 2 * \\
<\quad 2 * \\
<\quad 2 * \\
<\quad 2 * \\
<\quad 21\end{array}$ & $\begin{array}{l}<2 * \\
<2 * \\
<2 * \\
<2 * \\
<2 * \\
<2 *\end{array}$ & $\begin{array}{r}5 \\
30000 \\
750 \\
15 \\
20 \\
26000 \\
6\end{array}$ \\
\hline $\begin{array}{l}A \\
B \\
C \\
D \\
E \\
F \\
G\end{array}$ & 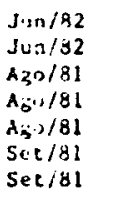 & $\begin{array}{l}25,0 \\
25,0 \\
19.0 \\
18,0 \\
20.0 \\
25.0 \\
29.0\end{array}$ & $\begin{array}{l}21,0 \\
21,0 \\
22,0 \\
20,0 \\
19,0 \\
22,0 \\
21,0\end{array}$ & $\begin{array}{r}6,6 \\
7,8 \\
7,5 \\
>8,2 \\
7,5 \\
6,9 \\
8,2\end{array}$ & $\begin{array}{l}- \\
- \\
1,5 \\
2,4 \\
1,4 \\
1,5 \\
3,0\end{array}$ & $\begin{array}{l}0,0 \\
0,0 \\
0,0 \\
0,0 \\
0,0 \\
0,0 \\
0,0\end{array}$ & $\begin{array}{l}r \\
<\quad 2 * \\
<2 * \\
<2 * \\
<2 * \\
350 \\
3 \quad 2 *\end{array}$ & $\begin{array}{l}<2 * \\
<2 * \\
<2 * \\
<2 * \\
<2 * \\
\quad 8 \\
<2 *\end{array}$ & $\begin{array}{r}2 \\
\quad 8 \\
<\quad 2 * \\
<2 * \\
<2 * \\
920 \\
<\quad 2 *\end{array}$ & $\begin{array}{l}<2 * \\
<\quad 2 * \\
<2 * \\
<2 * \\
<23 \\
<2 *\end{array}$ & $\begin{array}{c}300 \\
16000 \\
22000 \\
550 \\
7100 \\
>\quad 300 * \star \\
15\end{array}$ \\
\hline
\end{tabular}

- 2 ausente

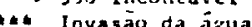




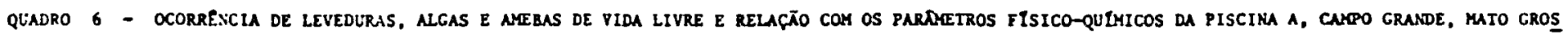
SO DO SUL (OUTUBRO DE 1981 E JANETRO, ABRIL E JUNHO DE 1982)

\begin{tabular}{|c|c|c|c|c|c|c|c|c|c|c|}
\hline \multirow{2}{*}{$\begin{array}{l}\text { PERIUDO } \\
\text { DE } \\
\text { COLETA }\end{array}$} & \multirow{2}{*}{\multicolumn{2}{|c|}{$\begin{array}{l}\text { TEMPERATURA } \\
\operatorname{AR}^{\left({ }^{\circ} \mathrm{C}\right)} \mathrm{XCUA}\end{array}$}} & \multirow[b]{2}{*}{ pH } & \multirow{2}{*}{$\begin{array}{l}\text { TURBIDEZ } \\
\text { (NTU) }\end{array}$} & \multirow{2}{*}{$\begin{array}{l}\text { CLORO RESIDEHL } \\
\text { LIVRE } \\
\text { (ng/1) }\end{array}$} & \multirow{2}{*}{$\begin{array}{l}\text { PONTOS } \\
\text { DE } \\
\text { COLETA }\end{array}$} & \multirow{2}{*}{$\begin{array}{l}\text { IIPOS } \\
\text { DE } \\
\text { COLETA }\end{array}$} & \multicolumn{3}{|c|}{$\begin{array}{llllllllll}X & E & S & 0 & L & I & A & D & 0 & S \\
\end{array}$} \\
\hline & & & & & & & & LEVEDURAs " & ALGAS & $\begin{array}{l}\text { AMEBAS DE VIDA } \\
\text { LIVRE }\end{array}$ \\
\hline Out/81 & 27.0 & 25,0 & 6.6 & 0,6 & 0,0 & $\begin{array}{l}\text { a9 } 01 \\
0922\end{array}$ & $\begin{array}{l}\text { Raspado } \\
\text { Kgua } \\
\text { Raspado } \\
\text { Rgua }\end{array}$ & $\begin{array}{l}\text { - } \\
\text { Exase negarivo } \\
\text { - } \\
\text { Exeme negativo }\end{array}$ & $\begin{array}{l}\text { Oscillatoria splendida } \\
\text { Exame negativo } \\
\text { Oscillatoria splendida } \\
\text { Exame ncgativo }\end{array}$ & $\begin{array}{l}\text { hartanellidae } \\
\text { Anebof lagelado } \\
\text { Amebof lagel ado } \\
\text { Amebof lagelado }\end{array}$ \\
\hline $\mathrm{Jan} / 82$ & 23,0 & 28,0 & 6,8 & 1,5 & 0.1 & $\begin{array}{l}\text { n9 } 01 \\
\text { n9 } 02\end{array}$ & $\begin{array}{l}\text { Raspado } \\
\text { Kgua } \\
\text { Raspado } \\
\text { Xgua }\end{array}$ & $\begin{array}{c}- \\
\text { Exame negativo } \\
- \\
\text { Exame negativo }\end{array}$ & $\begin{array}{l}\text { oscillatoria splendida } \\
\text { Exame negativo } \\
\text { oscillatoria splendida } \\
\text { Exame negativo }\end{array}$ & 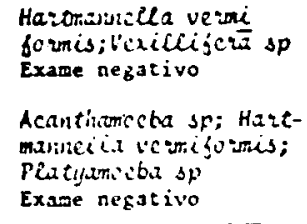 \\
\hline$A b r / s 2$ & 25,0 & 26,0 & 6,9 & 0,9 & 0,6 & $\begin{array}{l}\text { ap } 01 \\
\text { aP } 02\end{array}$ & $\begin{array}{l}\text { Raspado } \\
\text { Agua } \\
\text { Raspado } \\
\text { Agua }\end{array}$ & $\begin{array}{l}\text { - } \\
\text { Exase negativo } \\
- \\
\text { Exame negativo }\end{array}$ & $\begin{array}{l}\text { Scytoncma sp } \\
\text { Exame negativo } \\
\text { Scytonema sp } \\
\text { Exame negativo }\end{array}$ & 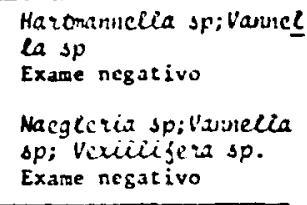 \\
\hline $\mathrm{Jun} / \mathrm{a} 2$ & 25,0 & 21,0 & 6,6 & - & 0,0 & $\begin{array}{l}\text { a8 } 01 \\
\text { n8 } 02\end{array}$ & $\begin{array}{l}\text { Raspado } \\
\lambda_{\text {gua }} \\
\text { Raspado } \\
\lambda_{\text {gua }}\end{array}$ & $\begin{array}{c}\text { - } \\
\text { Exame negativo } \\
- \\
\text { Exame negativo }\end{array}$ & $\begin{array}{l}\text { Scytonerax sp } \\
\text { Exame negativo } \\
\text { Scytonema sp } \\
\text { Exase aegativo }\end{array}$ & $\begin{array}{l}\text { Exame negativo } \\
\text { Exame negativo } \\
\text { Vaniella sp } \\
\text { Exase negativo }\end{array}$ \\
\hline
\end{tabular}

* Säo foi colecado arterial de parede. 


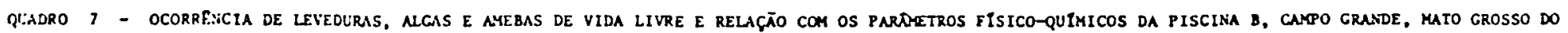
SUL (OLTUBRO DE 1981 E JANEIRO, ABRIL E JUNHO DE 1982)

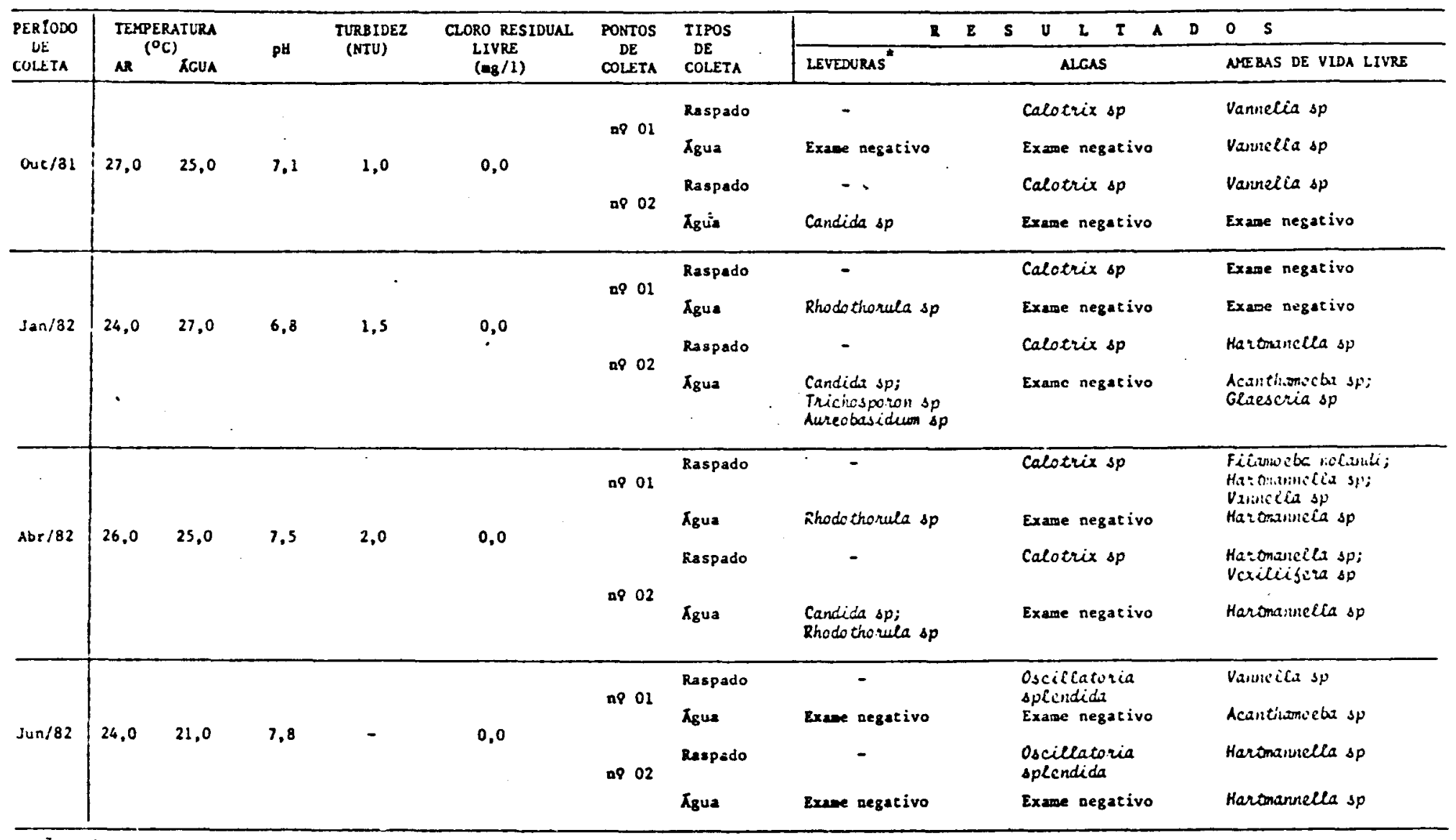

- sio foi coletado anterial de parede 


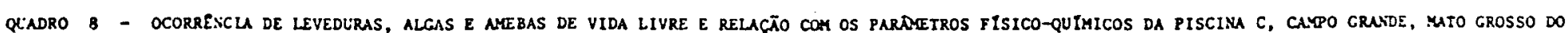
SUl (ACOSTO, NOVEYBRo dE 1981 E FEVEREIRO E MaIO DE 1982)

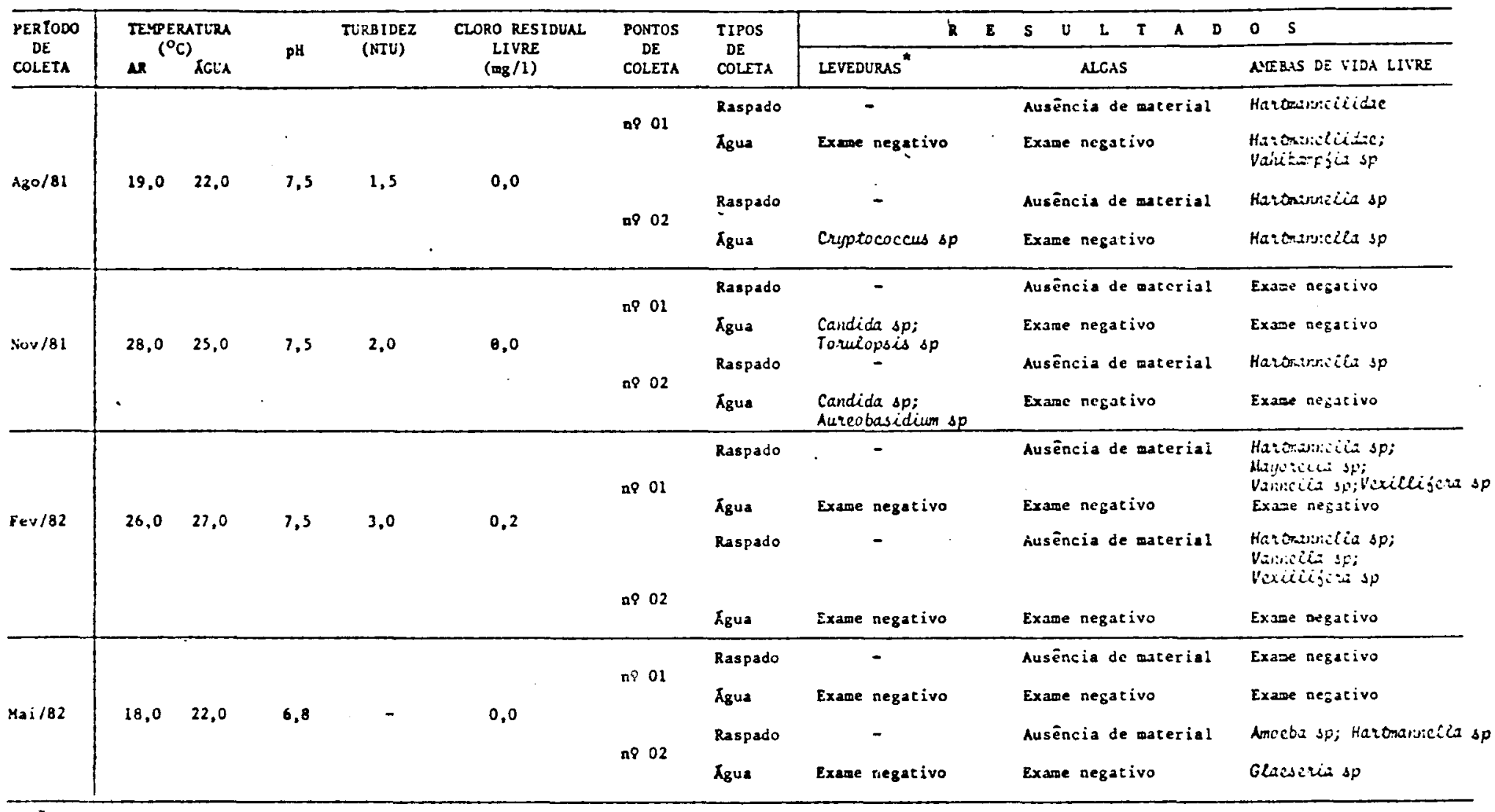

- Nío foi coletado material de parede 


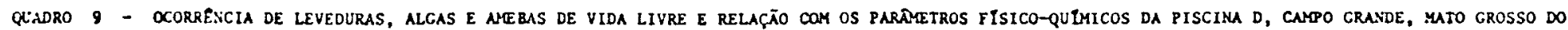
SLL (ACOSTO E NOVEMBRO DE 1981. FEVEREIRO E MUIO DE 1982)

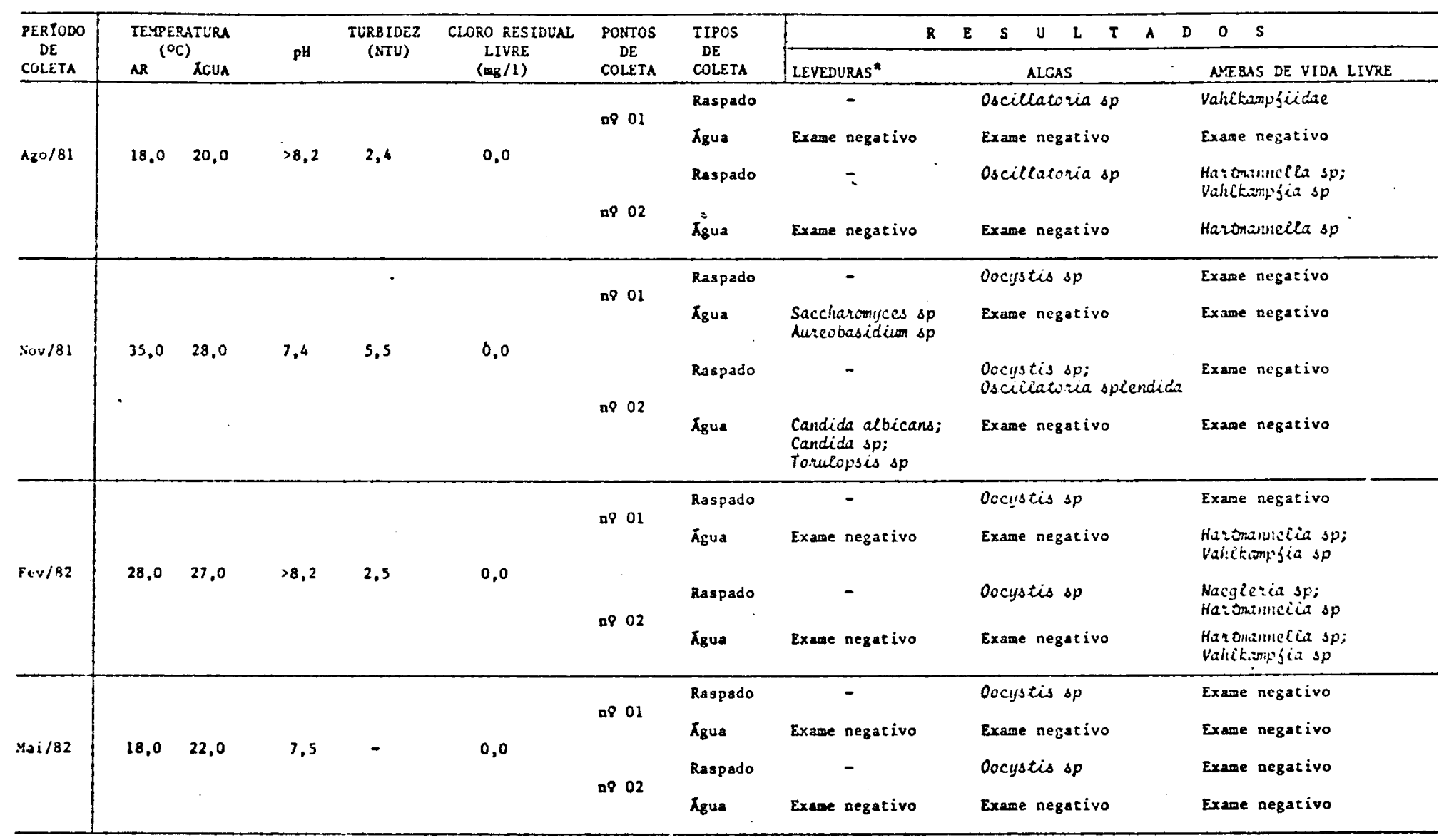

- Näo foi coletado naterial de parede 


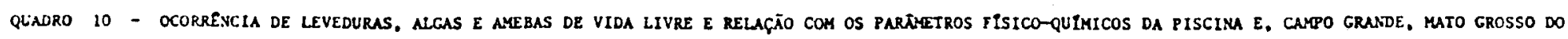
SUL (ACOSTO E NOVEMBRO DE 1981, FEVEREIRO E MALO DE 1982)

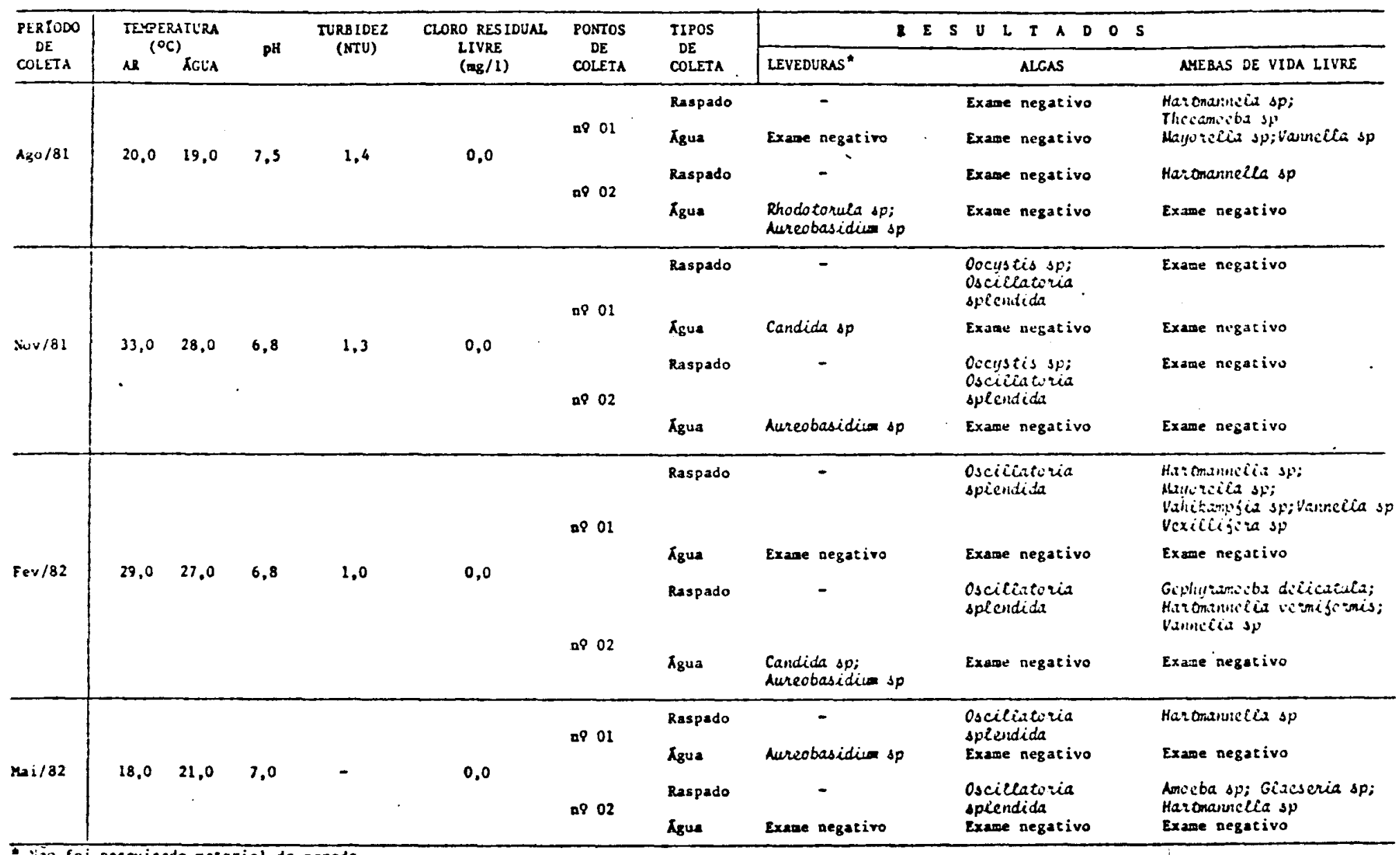




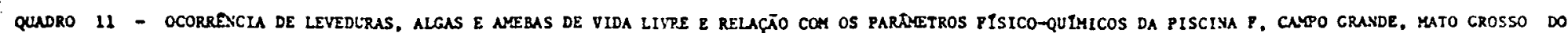
SUL (SETEYBRO E DEZEMBRO DE 1981, MARÇO E JLNHO DE 1982).

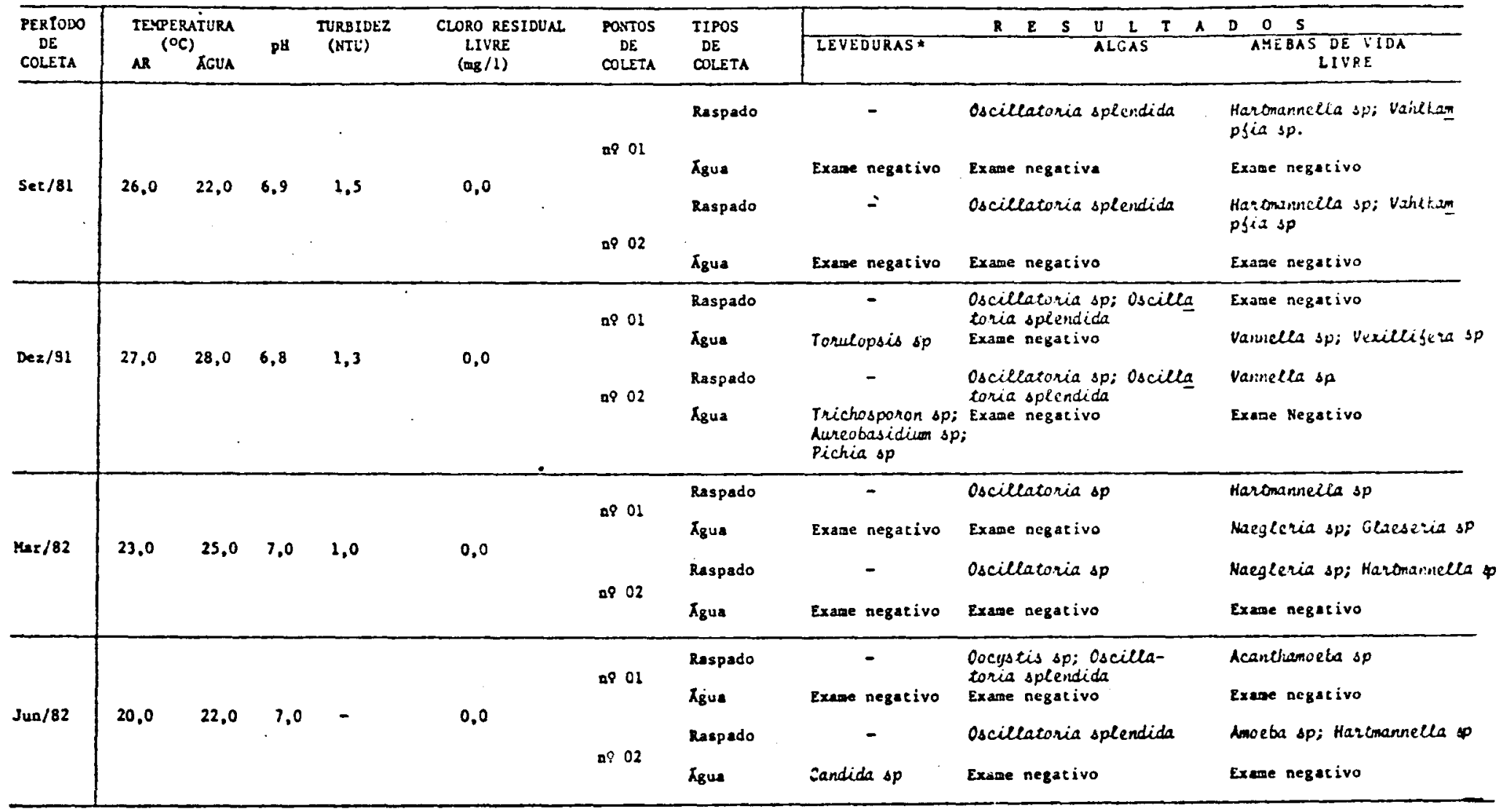

- Vïo foi coletado material de parede. 


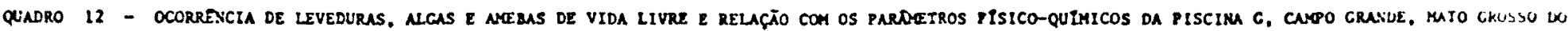
SUL (SETEMBRO E DEZEMBRO DE 1981, MARĢO E JUNHO DE 1982).

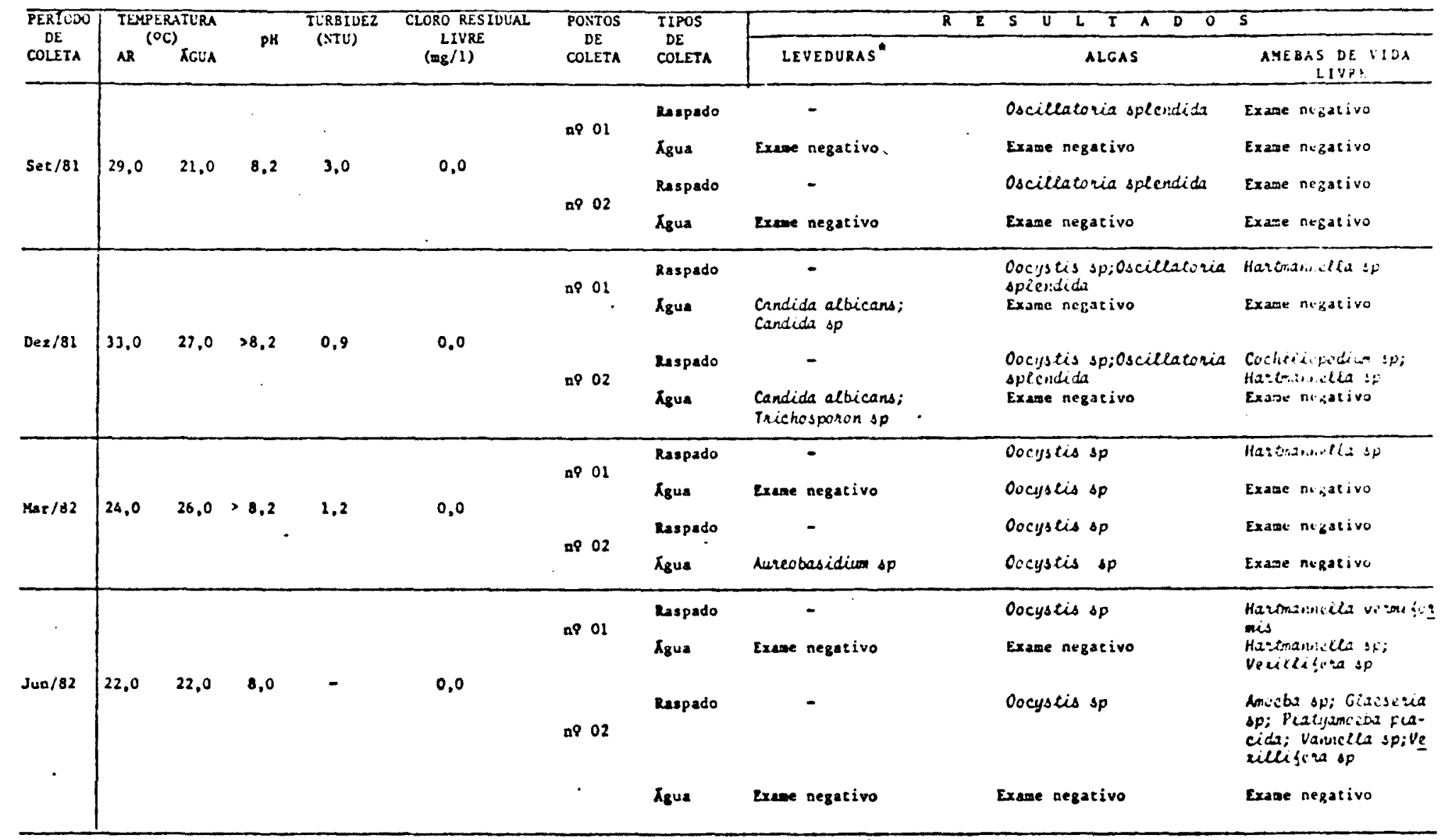

- Lä́o toi coletado anterial de parede. 
A N E X 0 II

(Tabelas de 1 a 6 ) 
IABELA 1 - PARTYETRCS FISICO-QULYICOS DE PISCINAS DA CIDADE DE CAMPO CRANDR, MATO CROSSO DO SUL (ACOSTO DE 1981 A JUNHO DE 1982)

\begin{tabular}{|c|c|c|c|c|c|c|c|c|c|c|c|c|}
\hline \multirow{2}{*}{ PIScivis } & \multirow{2}{*}{$\begin{array}{l}\text { PERIOODUS } \\
\text { DE } \\
\text { COLETA }\end{array}$} & \multicolumn{2}{|c|}{ TEPERATLRA $\left({ }^{\circ} \mathrm{C}\right)$} & \multirow{2}{*}{ pH } & \multirow{2}{*}{$\begin{array}{l}\text { TURBIDEZ } \\
\text { (NTU) }\end{array}$} & \multirow{2}{*}{ 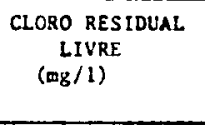 } & \multirow{2}{*}{$\begin{array}{l}\operatorname{COR} \\
(\mathrm{mg} / 1 \mathrm{Pt} / \mathrm{l})\end{array}$} & \multicolumn{4}{|c|}{$A L C A L I N I D A D E(\mathrm{mg} / 1 \mathrm{CaC}, \mathrm{g})$} & \multirow[t]{2}{*}{ CLURETIS } \\
\hline & & NR & $\pi G L A$ & & & & & $\begin{array}{c}\text { Hidróxidos } \\
\text { (HO) }\end{array}$ & $\begin{array}{c}\text { Carbonatos } \\
\left(\mathrm{CO}_{3}\right)\end{array}$ & $\begin{array}{c}\begin{array}{c}B \text { Bicarisunatus } \\
\left(\mathrm{HCO}_{3}\right)\end{array} \\
\end{array}$ & $T \circ \varepsilon a 1$ & \\
\hline B & $\begin{array}{l}\text { Our } / 81 \\
\mathrm{Jan} / 82 \\
\mathrm{Abr} / 82 \\
\mathrm{Jun} / 82\end{array}$ & $\begin{array}{l}27,0 \\
24,0 \\
25,0 \\
24,0\end{array}$ & $\begin{array}{l}25,0 \\
27,0 \\
25,0 \\
21,0\end{array}$ & $\begin{array}{l}7,1 \\
6.8 \\
7.5 \\
7,8\end{array}$ & $\begin{array}{l}1,0 \\
1,5 \\
2,0 \\
-\end{array}$ & $\begin{array}{l}0,0 \\
0,0 \\
0,0 \\
0,0\end{array}$ & $\begin{array}{l}3.0 \\
5.0 \\
7.0 \\
3,0\end{array}$ & $\begin{array}{l}0.0 \\
0.0 \\
0,0 \\
0,0\end{array}$ & $\begin{array}{l}0.0 \\
0.0 \\
0.0 \\
6.0\end{array}$ & $\begin{array}{r}30.0 \\
8.0 \\
40.0 \\
36,0\end{array}$ & $\begin{array}{r}30.0 \\
8.0 \\
40.0 \\
42.0\end{array}$ & $\begin{array}{l}13.5 \\
21.0 \\
31,5 \\
20.5\end{array}$ \\
\hline$c$ & $\begin{array}{l}\text { Ago/81 } \\
\text { Nuv/s1 } \\
\text { Fevis2 } \\
\because \pm 1 / 82\end{array}$ & $\begin{array}{l}19,0 \\
28,0 \\
26,0 \\
18,0\end{array}$ & $\begin{array}{l}22,0 \\
23,0 \\
27,0 \\
22,0\end{array}$ & $\begin{array}{l}7,5 \\
7,5 \\
7,5 \\
6,8\end{array}$ & $\begin{array}{l}1,5 \\
2,0 \\
3,0\end{array}$ & $\begin{array}{l}0,0 \\
0,0 \\
0,2 \\
0.0\end{array}$ & $\begin{array}{l}5.0 \\
4.0 \\
5.0 \\
5,0\end{array}$ & $\begin{array}{l}0,0 \\
0.0 \\
0.0 \\
0.0\end{array}$ & $\begin{array}{l}0,0 \\
0,0 \\
0,0 \\
0,0\end{array}$ & $\begin{array}{l}20.0 \\
21.0 \\
18.0 \\
10.0\end{array}$ & $\begin{array}{l}20,0 \\
21.0 \\
18,0 \\
10,0\end{array}$ & $\begin{array}{l}12.5 \\
11.0 \\
11,0 \\
4,1\end{array}$ \\
\hline$D$ & $\begin{array}{l}\text { dioj/81 } \\
\text { Sov/81 } \\
\text { Fev/32 } \\
\text { Mai } / 82\end{array}$ & $\begin{array}{l}19.0 \\
35.0 \\
28.0 \\
18.0\end{array}$ & $\begin{array}{l}20,0 \\
28,0 \\
27.0 \\
22.0\end{array}$ & $\begin{array}{r}>8,2 \\
7,4 \\
>8,2 \\
7.5\end{array}$ & $\begin{array}{l}2,4 \\
5,5 \\
2,5\end{array}$ & $\begin{array}{l}0,0 \\
0,0 \\
0,0 \\
0,0\end{array}$ & $\begin{array}{r}5,0 \\
10,0 \\
5,0 \\
5,0\end{array}$ & $\begin{array}{l}0,0 \\
0,0 \\
0,0 \\
0,0\end{array}$ & $\begin{array}{r}24,0 \\
0,0 \\
10,0 \\
0,0\end{array}$ & $\begin{array}{l}25,0 \\
30,0 \\
23,0 \\
21.0\end{array}$ & $\begin{array}{l}49,0 \\
30,0 \\
33,0 \\
21,0\end{array}$ & $\begin{array}{r}77,2 \\
85,9 \\
114,5 \\
108,5\end{array}$ \\
\hline $\mathbf{E}$ & 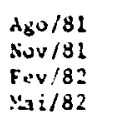 & $\begin{array}{l}20,0 \\
33,0 \\
29,0 \\
13,0\end{array}$ & $\begin{array}{l}19,0 \\
28,0 \\
27,0 \\
21,0\end{array}$ & $\begin{array}{l}7,5 \\
6,8 \\
6,8 \\
7,0\end{array}$ & $\begin{array}{l}1,4 \\
1,3 \\
1,0\end{array}$ & $\begin{array}{l}0,0 \\
0,0 \\
0,0 \\
0,0\end{array}$ & $\begin{array}{l}4,0 \\
5,0 \\
3,0 \\
5,0\end{array}$ & $\begin{array}{l}0,0 \\
0,0 \\
0,0 \\
0,0\end{array}$ & $\begin{array}{l}0,0 \\
0,0 \\
0,0 \\
0,0\end{array}$ & $\begin{array}{r}36,0 \\
16,0 \\
7,0 \\
14.0\end{array}$ & $\begin{array}{r}36,0 \\
16,0 \\
74,0 \\
24,0\end{array}$ & $\begin{array}{l}48,12 \\
62.5 \\
37,3 \\
46,3\end{array}$ \\
\hline $\boldsymbol{r}$ & $\begin{array}{l}\text { Set } / 31 \\
\text { Dez/81 } \\
\text { Mar/s2 } \\
\text { Jun } / 32\end{array}$ & $\begin{array}{l}25,0 \\
27,0 \\
23,0 \\
20,0\end{array}$ & $\begin{array}{l}22,0 \\
28,0 \\
25.0 \\
22,0\end{array}$ & $\begin{array}{l}6,9 \\
6,8 \\
7,0 \\
7.0\end{array}$ & $\begin{array}{l}1,5 \\
1,3 \\
1.0\end{array}$ & $\begin{array}{l}0,0 \\
0.0 \\
0,0 \\
0,0\end{array}$ & $\begin{array}{l}5,0 \\
4,0 \\
3,0 \\
4,0\end{array}$ & $\begin{array}{l}0,0 \\
0,0 \\
0,0 \\
0.0\end{array}$ & $\begin{array}{l}0,0 \\
0,0 \\
0,0 \\
0,0\end{array}$ & $\begin{array}{l}30.0 \\
20.0 \\
35,0 \\
14.0\end{array}$ & $\begin{array}{l}30.0 \\
20.0 \\
35.0 \\
14.0\end{array}$ & $\begin{array}{l}5.9 \\
7.0 \\
6.3 \\
5.5\end{array}$ \\
\hline G & $\begin{array}{l}\text { Set/31 } \\
\text { Dez/81 } \\
\operatorname{Mar} / 82 \\
\operatorname{Jun} / 82\end{array}$ & $\begin{array}{l}29,0 \\
33,0 \\
24,0 \\
22,0\end{array}$ & $\begin{array}{l}21,0 \\
27,0 \\
26,0 \\
22,0\end{array}$ & $\begin{array}{r}8,2 \\
>8.2 \\
>8,2 \\
8,0\end{array}$ & $\begin{array}{l}3,0 \\
0,9 \\
1,2\end{array}$ & $\begin{array}{l}0,0 \\
0,0 \\
0,0 \\
0,0\end{array}$ & $\begin{array}{r}10,0 \\
3,0 \\
6,0 \\
5,0\end{array}$ & $\begin{array}{l}0.0 \\
0.0 \\
0.0 \\
0.0\end{array}$ & $\begin{array}{r}2,0 \\
14,0 \\
6,0 \\
5,0\end{array}$ & $\begin{array}{l}44.0 \\
33.0 \\
38.0 \\
43,0\end{array}$ & $\begin{array}{l}45,0 \\
47,0 \\
44,0 \\
48,0\end{array}$ & $\begin{array}{l}203.5 \\
152.5 \\
161.5 \\
167.0\end{array}$ \\
\hline
\end{tabular}


TABELA 2 - BACTERIAS (NMP/100m1) E CONTAGEM PADRÃO DE COLÔNIAS/m1 DE PISCINAS DE CAMPO GRANDE, MATO GROSSO DO SUL (AGOSTO DE 1981 A JUNHO DE 1982).

\begin{tabular}{|c|c|c|c|c|c|c|c|c|c|}
\hline \multirow{2}{*}{$\begin{array}{c}\text { PISCINAS } \\
\text { A }\end{array}$} & $\begin{array}{l}\text { Coliformes } \\
\text { totais }\end{array}$ & \multicolumn{2}{|c|}{$\begin{array}{c}\text { Coliformes } \\
\text { fecais }\end{array}$} & \multicolumn{2}{|c|}{$\begin{array}{l}\text { Pseudomonas } \\
\text { aeruginosa }\end{array}$} & \multicolumn{2}{|c|}{$\begin{array}{l}\text { Estrepto } \\
\text { cocos } \mathrm{f} \text { e } \\
\text { cais }\end{array}$} & \multicolumn{2}{|c|}{$\begin{array}{l}\text { Contagem } \\
\text { padrão de } \\
\text { colônias }\end{array}$} \\
\hline & 27 & $<$ & 2 & & 7 & $<$ & 2 & $>$ & 300 \\
\hline B & 13 & & 2 & & 13 & $<$ & 2 & $>$ & 300 \\
\hline $\mathrm{C}$ & 22 & & 17 & $<$ & 2 & $<$ & 2 & & 23074 \\
\hline D & $<2$ & $<$ & 2 & & 13 & & 12 & & 2930 \\
\hline$E$ & 2 & $<$ & 2 & $<$ & 2 & & 2 & & 8035 \\
\hline$F$ & 1028 & & 33 & & 69 & & 31 & $>$ & 300 \\
\hline G & $<2$ & $<$ & 2 & & 2 & $<$ & 2 & & 29 \\
\hline
\end{tabular}

$>300$ incontāve1

$<\quad 2$ ausente 
TABELA 3 - CLASSIFICAÇÃO DAS PISCINAS, SEGUNDO A DETERMINAÇÃO DO NMP/100m1 DE COLIFORMES TOTAIS, CAMPO GRANDE, MATO GROSSO DO SUL (AGOSTO DE 1981 A JUNHO DE 1982)

\begin{tabular}{cc}
\hline CLASSIF ICAÇÃo & PISCINAS \\
\hline $\begin{array}{l}\text { Própria para o uso } \\
(<2)\end{array}$ & D, E, G \\
Imprópria para o uso & A, B, C, F \\
$(\geqslant 2)$ & \\
\hline
\end{tabular}

$(<2)$ coliformes totais ausentes 
TABELA 4 - LEVEDURAS DE PISCINAS DE CAMPO GRANDE, MATO GROSSO DO SUL (AGOSTO DE 1981 A JUNHO DE 1982)

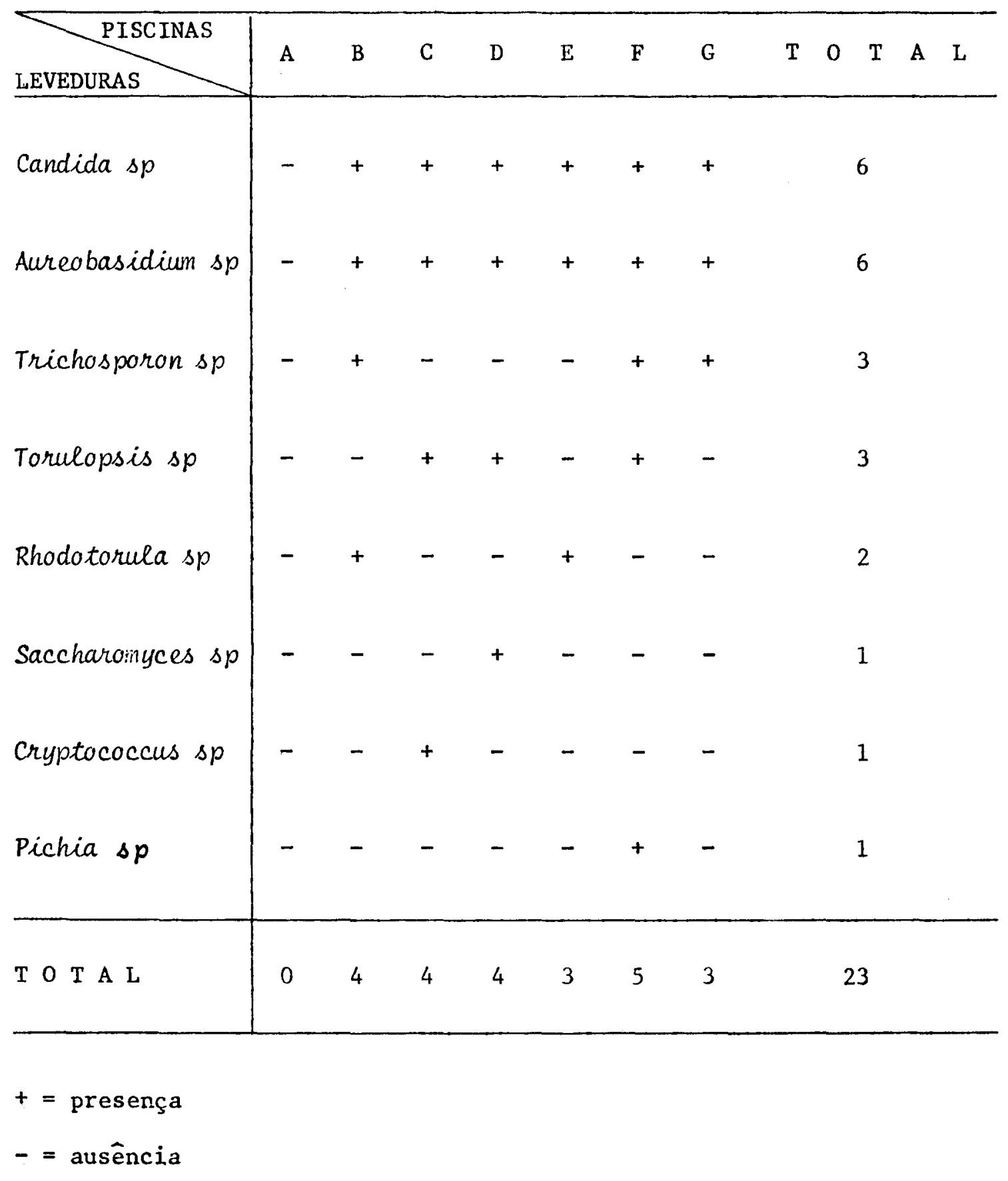


TABELA 5 - ALGAS DE PISCINAS DE CAMPO GRANDE, MATO GROSSO DO SUL (AGOSTO DE 1981 A JUNHO DE 1982)

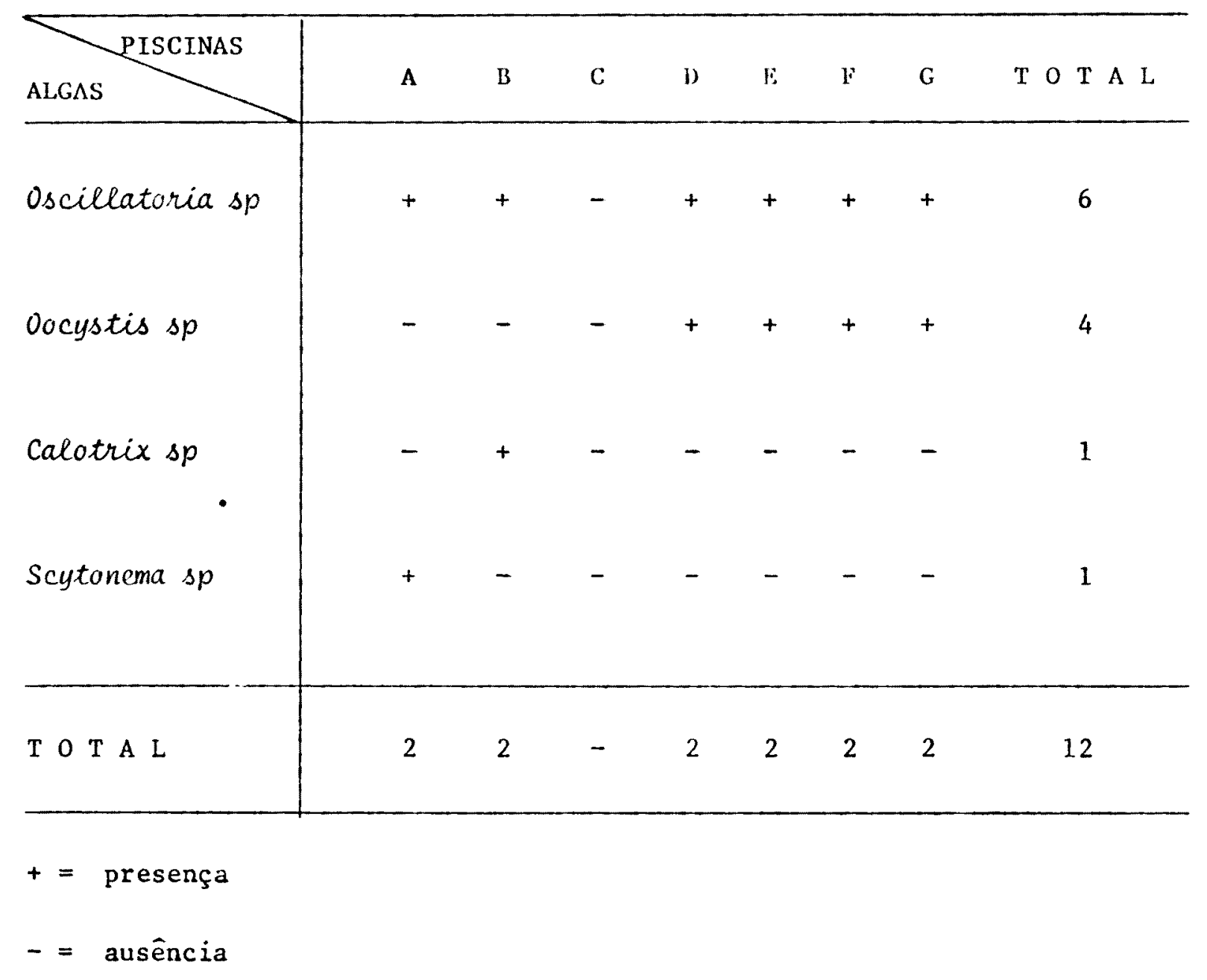


TABELA 6 - AMEBAS DE VIDA LIVRE DE l'ISCINAS DE CAMPO CRANIE, MATO gROSSO DO SUL (AGOSTO DE 1981 A JUNhO DE 1982)

\begin{tabular}{|c|c|c|c|c|c|c|c|c|}
\hline $\begin{array}{l}\text { AMEBAS } \\
\text { DE VIDA LIVRE }\end{array}$ & A & B & $\mathrm{C}$ & $\mathrm{D}$ & $\mathrm{E}$ & $\mathbf{F}$ & G & $\mathrm{T} O \mathrm{TAL}$ \\
\hline Hartmannella sp & + & + & + & + & + & + & + & 7 \\
\hline Vannella sp & + & + & + & - & + & + & + & 6 \\
\hline Vexillifera sp & + & + & + & - & + & + & + & 6 \\
\hline Amoeba sp & - & - & + & - & + & + & + & 4 \\
\hline Glaeseria sp & - & + & + & - & + & + & + & 5 \\
\hline Vahekamp fia sp & - & - & + & + & + & + & - & 4 \\
\hline Acanthamoeba sp & + & + & - & - & - & + & - & 3 \\
\hline Naegleria sp & + & - & - & + & - & + & - & 3 \\
\hline Mayonella sp & - & - & + & - & + & - & - & 2 \\
\hline Platyamoeba sp & + & - & - & - & - & - & + & 2 \\
\hline Cochliopodium sp & - & - & - & - & - & - & + & 1 \\
\hline Filamoeba sp & - & + & - & - & - & - & - & 1 \\
\hline Gephyramoeba sp & - & - & - & - & + & - & - & 1 \\
\hline Thecamoeba sp & - & - & - & - & + & - & - & 1 \\
\hline $\mathrm{T} \circ \mathrm{T} A \mathrm{~L}$ & 6 & 6 & 7 & 3 & 9 & 8 & 7 & 46 \\
\hline
\end{tabular}

$$
\begin{aligned}
& +=\text { presença } \\
& -=\text { ausência }
\end{aligned}
$$

